CAROLINA OLIVEIRA ZAMBRANA

REGENERAÇÃO DE CARVÃO ATIVADO UTILIZADO PARA ADSORÇÃO DE PESTICIDA POR MEIO DE PROCESSOS OXIDATIVOS AVANÇADOS

São Paulo

2013 


\title{
REGENERAÇÃO DE CARVÃO ATIVADO UTILIZADO PARA ADSORÇÃO DE PESTICIDA POR MEIO DE PROCESSOS OXIDATIVOS AVANÇADOS
}

\author{
Dissertação apresentada à Escola \\ Politécnica da Universidade de São Paulo \\ para obtenção do título de Mestre em \\ Engenharia \\ Área de concentração: Engenharia \\ Química
}

Orientador: Prof. Dr. Antonio Carlos Silva Costa Teixeira

São Paulo

2013 


\begin{tabular}{|l|} 
Este exemplar foi revisado e alterado em relação à versão original, \\
sob responsabilidade única do autor e com a anuência de seu orientador. \\
São Paulo, 15 de julho de 2013. \\
Assinatura do autor \\
Assinatura do orientador
\end{tabular}

\section{FICHA CATALOGRÁFICA}

Zambrana, Carolina Oliveira

Regeneração de carvão ativado utilizado para adsorção de pesticida por meio de processos oxidativos avançados / C.O. Zambrana. -- versão corr. -- São Paulo, 2013.

$99 \mathrm{p}$.

Dissertação (Mestrado) - Escola Politécnica da Universidade de São Paulo. Departamento de Engenharia Química.

1. Carvão ativado (Regeneração) 2. Absorção 3. Oxidação (Processos) I. Universidade de São Paulo. Escola Politécnica. Departamento de Engenharia Química II. t. 


\section{AGRADECIMENTOS}

Agradeço a todos que tornaram este trabalho possível, particularmente ao Prof. Dr. Antonio Carlos S. C. Teixeira, pelas discussões, pelas sugestões e por ter sido um orientador presente. Agradeço aos meus pais e ao Lucas Monteiro Ruzene por me aguentarem pacientemente na alegria e na tristeza, na saúde e na doença, por todos os dias deste trabalho.

Aos colegas de laboratório e do Departamento de Engenharia Química da Escola Politécnica da USP, que além das discussões profissionais, colaboraram para meu crescimento pessoal também.

Ao Luis Luís Fernando Mercier Franco, pelas conversas intelectuais e, claro, pela enorme ajuda na disciplina "Fundamentos de Processos em Engenharia Química I"; aos meus amigos e familiares, que me apoiaram na minha escolha profissional.

Aos meus amigos do Instituto de Química de São Carlos, em especial a Maria Luiza, que me ajudou num momento crítico do meu mestrado: quando o HPLC apresentou problemas (e não foram poucas vezes).

E à CAPES e ao CNPq pelo suporte financeiro. 


\section{RESUMO}

Como os tratamentos convencionais de água e efluentes normalmente não reduzem as concentrações de pesticidas significativamente, torna-se necessário utilizar outros tipos de tratamento associados e uma alternativa é o póstratamento empregando carvão ativado (CA) para adsorção desses poluentes. Sua viabilidade econômica está associada ao seu reúso. O desenvolvimento de novas técnicas de regeneração de CA contaminado após uso, como o emprego de Processos Oxidativos Avançados (POA), tem recebido muita atenção. Os POA são caracterizados pela geração de radicais hidroxila (HO•), que são fortes oxidantes capazes de mineralizar uma vasta gama de substâncias, geralmente sem a necessidade de disposicão final. Nesse sentido, no presente trabalho estudou-se a aplicação dos POA baseados na peroxidação assistida por radiação ultravioleta $\left(\mathrm{H}_{2} \mathrm{O}_{2} / \mathrm{UV}\right)$ e oxidação promovida por peroximonossulfato de potássio (PMS) para regeneração de CA contaminado com o herbicida amicarbazona. Os processos estudados consistiram de duas etapas: adsorção, contactando-se a solução contendo o herbicida com o CA por um período pré-determinado; e tratamento, empregando os processos $\mathrm{H}_{2} \mathrm{O}_{2} / \mathrm{UV}$ ou PMS. Os resultados para 0 sistema $\mathrm{H}_{2} \mathrm{O}_{2} / \mathrm{UV}$ indicaram que houve manutenção do poder de adsorção do $\mathrm{CA}$, já que se observou uma constante na capacidade de adsorção após ciclos de regeneração consecutivos. Para o processo baseado em PMS, a regeneração é aparentemente efetiva, sendo o tempo de regeneração, para uma razão oxidante/contaminante mais alta, importante neste processo oxidativo, já que maiores tempos de contato entre a solução contendo o PMS e o carvão contaminado resultaram em uma melhora, mesmo que pequena, na capacidade do CA em adsorver a amicarbazona.

Palavras-chave: Carvão ativado. Amicarbazona. Regeneração. Processos oxidativos avançados. 


\section{ABSTRACT}

Conventional water and wastewater treatment processes usually do not significantly reduce the concentrations of pesticides, thus other types of treatment are necessary. An alternative is the use of activated carbon (AC) for the adsorption of these pollutants, although its economic viability is directly associated with its reuse. The development of new techniques for regenerating $A C$ contaminated after usage, as the Advanced Oxidation Processes (AOP), have received much attention. AOP are characterized by the generation of hydroxyl radicals ( $\mathrm{HO} \cdot)$, which are strong oxidants able to mineralize a wide range of substances, often without the need for final disposal. Thus, the present study investigated the application of AOPs based on the ultraviolet-assisted peroxidation $\left(\mathrm{H}_{2} \mathrm{O}_{2} / \mathrm{UV}\right)$ and oxidation promoted by potassium peroxymonosulfate (PMS) for the regeneration of $\mathrm{AC}$ contaminated with the herbicide amicarbazone. The processes studied consisted of two steps: adsorption, by contacting the solution containing the herbicide with the $\mathrm{AC}$ for a certain period of time; and treatment, using the $\mathrm{H}_{2} \mathrm{O}_{2} / \mathrm{UV}$ or PMS processes. The results for the $\mathrm{H}_{2} \mathrm{O}_{2} / \mathrm{UV}$ system showed a maintenance of the AC's adsorption capacity, since there was observed a constant adsorption capacity after consecutive regeneration cycles. For the PMSbased process, regeneration appears to be more effective with time exposure associated with higher oxidant/contaminant ratios, shown to be the most important factor in this case, since longer contact periods between the oxidant and the contaminated activated carbon resulted in an improvement, however small, in the ability of AC to adsorb amicarbazone.

Keywords: Activated Carbon. Amicarbazone. Regeneration. Advanced oxidation processes. 


\section{LISTA DE FIGURAS}

Figura 1- Porosidade em carvões ativados. 26

$\begin{array}{ll}\text { Figura } 2 \text { - Grupos funcionais encontrados na superfície dos carvões. } & 27\end{array}$

Figura 3 - Esboço dos cinco tipos de isotermas de adsorção segundo 33

Brunauer.

Figura 4 - Ciclo da combinação adsorção-oxidação. 42

Figura 5 - Desenho esquemático do reator acoplado à coluna de leito fixo $\quad 45$ de carvão ativado.

Figura 6 - Desenho esquemático do reator acoplado à coluna de leito fixo $\quad 46$ de carvão ativado para a regeneração por processo oxidativo $\mathrm{H}_{2} \mathrm{O}_{2} / \mathrm{UV}$.

Figura 7 - Representação esquemática da distribuição dos experimentos segundo o planejamento experimental Doehlert. $X_{1}$ : valor codificado correspondente à concentração de amicarbazona e $X_{2}$ : valor codificado correspondente à massa de carvão ativado. Os números dos experimentos são indicados nos vértices e no centro do hexágono.

Figura 8 - Gradiente empregado na análise de amicarbazona por HPLC. $\quad 53$

Figura 9 - Isoterma de adsorção do carvão ativado Filtrasorb 100.

Figura 10 - Micrografia por MEV da superfície de carvão ativado, com 58 aumento de 250 vezes.

Figura 11 - Micrografia por MEV da superfície de carvão ativado, com aumento de 1000 vezes.

Figura 12 - Micrografia por MEV da superfície de carvão ativado, com aumento de 5000 vezes.

Figura 13 - Distribuição granulométrica de uma amostra de carvão ativado em função da abertura das peneiras ( $\mathrm{mm}$ ).

Figura 14 - Análise realizada para estudo do efeito do aumento da vazão no processo de adsorção, com resultados de COT, para uma vazão de $50 \mathrm{~L}$ $\mathrm{h}^{-1}$ e com concentração inicial de amicarbazona de $50 \mathrm{mg} \mathrm{L}^{-1}$.

Figura 15 - Análise realizada para estudo do efeito do aumento da vazão 
no processo de adsorção, com resultados de [AMZ] obtidos por HPLC, para uma vazão de $50 \mathrm{~L} \mathrm{~h}^{-1}$ e com concentração inicial de amicarbazona de 50 $\mathrm{mg} \mathrm{L}^{-1}$.

Figura 16 - Análise realizada para estudo do efeito do aumento da vazão no processo de adsorção, com resultados de COT, para uma vazão de $10 \mathrm{~L}$ $\mathrm{h}^{-1}$ e com concentração inicial de amicarbazona de $50 \mathrm{mg} \mathrm{L}^{-1}$.

Figura 17 - Análise realizada para estudo do efeito do aumento da vazão 64 no processo de adsorção, com resultados de [AMZ] obtidos por HPLC para uma vazão de $10 \mathrm{~L} \mathrm{~h}^{-1}$ e com concentração inicial de amicarbazona de 50 $\mathrm{mg} \mathrm{L}^{-1}$.

Figura 18 - Ensaio de dessorção da amicarbazona a partir do carvão 65 ativado contaminado com o herbicida.

Figura 19 - Medidas de COT da água.

Figura 20 - Curvas de adsorção obtidas nos experimentos realizados com 67 recirculação da solução de amicarbazona (AMZ) à vazão de $50 \mathrm{~L} \mathrm{~h}^{-1} \mathrm{em}$ coluna de leito fixo de carvão ativado, conforme a matriz Doehlert (Tabela 6 e Figura 8, seção 4.3.1). Condições: exp 1 ([AMZ $]_{0}=60 \mathrm{mg} \mathrm{L}^{-1}$; massa de carvão $=5,5 \mathrm{~g}$ ), exp 2 ([AMZ] $]_{0}=100 \mathrm{mg} \mathrm{L}^{-1}$; massa de carvão=5,5 g), exp 3 ([AMZ $]_{0}=80 \mathrm{mg} \mathrm{L}^{-1}$; massa de carvão=9,4 g), exp 4 ([AMZ $]_{0}=20 \mathrm{mg} \mathrm{L}^{-1}$; massa de carvão=5,5 g), exp 5 ([AMZ $]_{0}=40 \mathrm{mg} \mathrm{L}^{-1}$; massa de carvão=1,6 g), $\exp 6\left([A M Z]_{0}=80 \mathrm{mg} \mathrm{L}^{-1}\right.$; massa de carvão=1,6 g) e exp $7\left([A M Z]_{0}=40 \mathrm{mg}\right.$ $\mathrm{L}^{-1}$; massa de carvão=9,4 g).

Figura 21 - Diagrama de Pareto correspondente aos resultados da matriz 68 experimental Doehlert (Tabela 6 e Figura 7, seção 4.3.1), onde o valor de t de Student com $7-6=1$ grau de liberdade e 95\% de confiança é 12,706.

Figura 22 - Gráfico de contorno da superfície de resposta

Figura 23 - Curvas de adsorção de amicarbazona (AMZ) obtidas nos 70 experimentos realizados com recirculação da solução de amicarbazona a $50 \mathrm{~L} \mathrm{~h}^{-1}$ e $25^{\circ} \mathrm{C}$ em coluna de leito fixo contendo $7,5 \mathrm{~g}$ de carvão ativado, pH não ajustado no início. Condições: ciclo 1: $[A M Z]_{0}=20,1 \mathrm{mg} \mathrm{L}^{-1}$; ciclo 2: $[A M Z]_{0}=19,8 \mathrm{mg} \mathrm{L}^{-1}$; e ciclo 3: $[A M Z]_{0}=19,7 \mathrm{mg} \mathrm{L}^{-1}$.

Figura 24 - Curvas de adsorção de amicarbazona (AMZ) obtidas nos 70 experimentos realizados com recirculação da solução de amicarbazona 
(AMZ) a $50 \mathrm{~L} \mathrm{~h}^{-1}$ e $25^{\circ} \mathrm{C}$ em coluna de leito fixo contendo $7,5 \mathrm{~g}$ de carvão ativado, $\mathrm{pH}$ não ajustado no início. Condições: ciclo 1: $[\mathrm{AMZ}]_{0}=39,9 \mathrm{mg} \mathrm{L}^{-1}$; ciclo 2: $[A M Z]_{0}=40,2 \mathrm{mg} \mathrm{L}^{-1}$; e ciclo 3: $[A M Z]_{0}=40,2 \mathrm{mg} \mathrm{L}^{-1}$.

Figura 25 - Curvas de adsorção de amicarbazona (AMZ) obtidas nos experimentos realizados com recirculação da solução de amicarbazona (AMZ) a $50 \mathrm{~L} \mathrm{~h}^{-1}$ e $25^{\circ} \mathrm{C}$ em coluna de leito fixo contendo $7,5 \mathrm{~g}$ de carvão ativado, $\mathrm{pH}$ não ajustado no início. Condições: ciclo 1: $[A M Z]_{0}=59,7 \mathrm{mg} \mathrm{L}^{-1}$; ciclo 2: $[A M Z]_{0}=59,5 \mathrm{mg} \mathrm{L}^{-1}$; e ciclo 3: $[A M Z]_{0}=60,1 \mathrm{mg} \mathrm{L}^{-1}$.

Figura 26 - Curvas de adsorção de amicarbazona (AMZ) obtidas nos 71 experimentos realizados com recirculação da solução de amicarbazona (AMZ) a $50 \mathrm{~L} \mathrm{~h}^{-1}$ e $25^{\circ} \mathrm{C}$ em coluna de leito fixo contendo $7,5 \mathrm{~g}$ de carvão ativado, $\mathrm{pH}$ não ajustado no início. Condições: ciclo 1: $[\mathrm{AMZ}]_{0}=78,9 \mathrm{mg} \mathrm{L}^{-1}$; ciclo 2: $[A M Z]_{0}=79,3 \mathrm{mg} \mathrm{L}^{-1}$; e ciclo 3: $[A M Z]_{0}=79,2 \mathrm{mg} \mathrm{L}^{-1}$.

Figura 27 - Curvas de adsorção de amicarbazona (AMZ) obtidas nos 72 experimentos realizados com recirculação da solução de amicarbazona (AMZ) a $50 \mathrm{~L} \mathrm{~h}^{-1}$ e $25^{\circ} \mathrm{C}$ em coluna de leito fixo contendo $7,5 \mathrm{~g}$ de carvão ativado, $\mathrm{pH}$ não ajustado no início. Condições: ciclo 1: [AMZ] $]_{0}=100,4 \mathrm{mg} \mathrm{L}^{-1}$; ciclo 2: $[A M Z]_{0}=100,1 \mathrm{mg} \mathrm{L}^{-1}$; e ciclo 3: $[A M Z]_{0}=99,7 \mathrm{mg} \mathrm{L}^{-1}$.

Figura 28 - Curvas de adsorção de amicarbazona (AMZ) em carvão ativado 72 obtidas nos experimentos realizados com recirculação da solução de amicarbazona a $50 \mathrm{~L} \mathrm{~h}^{-1}$ e $25^{\circ} \mathrm{C}$ em coluna de leito fixo contendo $7,5 \mathrm{~g}$ de carvão ativado, $\mathrm{pH}$ ajustado inicialmente para 3.

Figura 29 - Isotermas de adsorção de amicarbazona (AMZ) obtidas a $25^{\circ} \mathrm{C}$, 73 para diferentes condições de $\mathrm{pH}$ inicial (sem ajuste com pH próximo a 7 e com ajuste em $\mathrm{pH}=3$.

Figura 30 - Ensaios de saturação do carvão ativado, utilizando uma 74 solução de amicarbazona (AMZ) com concentração de $500 \mathrm{mg} \mathrm{L}^{-1}$ para 10 $\mathrm{g}$ de carvão ativado. Experimentos realizados em coluna de leito fixo (Figura 5).

Figura 31 - Resultados dos ensaios de adsorção/regeneração. 75 Regeneração do carvão ativado em cada ciclo por meio de processo oxidativo avançado $\mathrm{H}_{2} \mathrm{O}_{2} / \mathrm{UV}$, com lâmpada UVC de $125 \mathrm{~W}$ de potência e com alimentação de peróxido à vazão de $5 \mathrm{~mL} \mathrm{~h}^{-1}$, por um período de 4 
horas e pH próximo a 7.

Figura 32 - Resultados dos ensaios de adsorção/regeneração. 77 Regeneração do carvão ativado em cada ciclo por meio de processo oxidativo avançado $\mathrm{H}_{2} \mathrm{O}_{2} / \mathrm{UV}$, com uma lâmpada de $125 \mathrm{~W}$ de potência e com alimentação de peróxido na vazão de $5 \mathrm{~mL} \mathrm{~h}^{-1}$, sendo que outros $5 \mathrm{~mL}$ de peróxido foram adicionados no tempo zero, totalizando $25 \mathrm{~mL}$ de peróxido, por um período de 4 horas e pH próximo a 7 .

Figura 33 - Resultados dos ensaios de adsorção/regeneração. 78 Regeneração do carvão ativado por meio de processo oxidativo avançado com PMS, por 1 hora, na proporção molar oxidante/contaminante de 1:1 e pH próximo a 7.

Figura 34 - Resultados dos ensaios de adsorção/regeneração. 78 Regeneração do carvão ativado, por meio de processo oxidativo avançado com PMS, por 2 horas, na proporção molar oxidante/contaminante de 1:1 e pH próximo a 7.

Figura 35 - Resultados dos ensaios de adsorção/regeneração. 79 Regeneração do carvão ativado, por meio de processo oxidativo avançado com PMS, por 4 horas, na proporção molar oxidante/contaminante de 1:1 e pH próximo a 7.

Figura 36 - Resultados dos ensaios de adsorção/regeneração. 79 Regeneração do carvão ativado, por meio de processo oxidativo avançado com PMS, por 1 hora, na proporção molar oxidante/contaminante de 2:1 e pH próximo a 7.

Figura 37 - Resultados dos ensaios de adsorção/regeneração. 80 Regeneração do carvão ativado, por meio de processo oxidativo avançado com PMS, por 2 horas, na proporção molar oxidante/contaminante de 2:1 e pH próximo a 7.

Figura 38 - Resultados dos ensaios de adsorção/regeneração. 80 Regeneração do carvão ativado, por meio de processo oxidativo avançado com PMS, por 4 horas, na proporção molar oxidante/contaminante de 2:1 e pH próximo a 7.

Figura 39 - Ciclos de adsorção do carvão ativado.

Figura 40 - Resultados dos ensaios de adsorção/regeneração. 82 
Regeneração do carvão ativado, por meio de processo oxidativo avançado com PMS, por 2 horas, na proporção molar oxidante/contaminante de 2:1 e pH próximo a 7.

Figura 41 - Resultados dos ensaios de adsorção/regeneração. Regeneração do carvão ativado, por meio de processo oxidativo avançado com PMS, por 2 horas, na proporção molar oxidante/contaminante de 1:1 e pH próximo a 7.

Figura 42 - Resultados dos ensaios de adsorção/regeneração.

Regeneração do carvão ativado, por meio de processo oxidativo avançado com PMS, por 2 horas, na proporção molar oxidante/contaminante de 1:2 e pH próximo a 7.

Figura 43 - Resultados dos ensaios de adsorção/regeneração. 84 Regeneração do carvão ativado, por meio de processo oxidativo avançado com PMS, por 2 horas, na proporção molar oxidante/contaminante de 10:1 e pH próximo a 7.

Figura 44 - Resultados dos ensaios de adsorção/regeneração. 84 Regeneração do carvão ativado, por meio de processo oxidativo avançado com PMS, por 2 horas, na proporção molar oxidante/contaminante de 20:1 e pH próximo a 7.

Figura 45 - Resultados dos ensaios de adsorção/regeneração. 85 Regeneração do carvão ativado, por meio de processo oxidativo avançado com PMS, por 2 horas, na proporção molar oxidante/contaminante de 30:1 e pH próximo a 7.

Figura 46 - Resultados dos ensaios de adsorção/regeneração. 85 Regeneração do carvão ativado, por meio de processo oxidativo avançado com PMS, por 2 horas, na proporção molar oxidante/contaminante de 40:1 e pH próximo a 7.

Figura 47 - Resultados dos ensaios de adsorção/regeneração.

Regeneração do carvão ativado, por meio de processo oxidativo avançado com PMS, por 12 horas, na proporção molar oxidante/contaminante de 2:1 e pH próximo a 7.

Figura 48 - Resultados dos ensaios de adsorção/regeneração. 86 Regeneração do carvão ativado, por meio de processo oxidativo avançado 
com PMS, por 12 horas, na proporção molar oxidante/contaminante de 1:1 e pH próximo a 7.

Figura 49 - Resultados dos ensaios de adsorção/regeneração. 87 Regeneração do carvão ativado, por meio de processo oxidativo avançado com PMS, por 12 horas, na proporção molar oxidante/contaminante de 1:2. Figura 50 - Resultados dos ensaios de adsorção/regeneração. 87 Regeneração do carvão ativado, por meio de processo oxidativo avançado com PMS, por 24 horas, na proporção molar oxidante/contaminante de 2:1 e pH próximo a 7.

Figura 51 - Resultados dos ensaios de adsorção/regeneração. 88 Regeneração do carvão ativado, por meio de processo oxidativo avançado com PMS, por 24 horas, na proporção molar oxidante/contaminante de 1:1 e pH próximo a 7.

Figura 52 - Resultados dos ensaios de adsorção/regeneração. 88 Regeneração do carvão ativado, por meio de processo oxidativo avançado com PMS, por 24 horas, na proporção molar oxidante/contaminante de 1:2 e pH próximo a 7. 


\section{LISTA DE TABELAS}

Tabela 1- Classificação dos poros de um carvão ativado 26

Tabela 2 - Materiais adsorventes e suas aplicações 30

Tabela 3 - Análise comparativa de diferentes adsorventes comerciais 31

Tabela 4 - Potencial padrão de redução de diferentes oxidantes 37

Tabela 5 - Vantagens e desvantagens do processo $\mathrm{H}_{2} \mathrm{O}_{2} / \mathrm{UV} \quad 39$

Tabela 6 - Domínio experimental dos valores nominais das variáveis 48 estudadas.

Tabela 7 - Resultados obtidos na análise do teor de umidade. 60

Tabela 8 - Resultados obtidos na análise do teor de cinzas. 61

Tabela 9 - Respostas obtidas para os experimentos realizados com 67 recirculação da solução de amicarbazona em coluna de leito fixo de carvão ativado, com base na matriz experimental Doehlert (Tabela 6 e Figura 8, seção 4.3.1). 


\section{LISTA DE SIGLAS}

$\begin{array}{cl}\text { AMZ } & \text { Amicarbazona } \\ \text { IBGE } & \text { Instituto Brasileiro de Geografia e Estatística } \\ \text { EPA } & \text { Environmental Protection Agency } \\ \text { POA } & \text { Processo Oxidativo Avançado } \\ \text { PMS } & \text { Peroximonossulfato de potássio } \\ \mathrm{H}_{2} \mathrm{O}_{2} & \text { Peróxido de hidrogênio } \\ \text { UV } & \text { Radiação ultravioleta } \\ \text { CAG } & \text { Carvão ativado granular } \\ \text { IUPAC } & \text { União Internacional de Química Pura e Aplicada } \\ \text { CA } & \text { Carvão ativado } \\ \text { CAP } & \text { Carvão ativado pulverizado } \\ \text { P.A. } & \text { Padrão Analítico } \\ \text { HPLC } & \text { Cromatografia Líquida de Alta Eficiência } \\ \text { EPH } & \text { Potencial padrão de redução } \\ \text { TOC } & \text { Carbono Orgânico Total } \\ \text { NDIR } & \text { Infravermelho não dispersível } \\ \text { TC } & \text { Carbono Total } \\ \text { IC } & \text { Carbono Inorgânico } \\ \text { BET } & \text { Brunauer - Emmett - Teller } \\ \text { GPQVA } & \text { Grupo de Pesquisa em Química Verde e Ambiental } \\ \text { MEV } & \text { Microscopia eletrônica de varredura } \\ \text { ES } & \text { Elétrons secundários } \\ \text { ABNT } & \text { Associação Brasileira de Normas Técnicas }\end{array}$




\section{LISTA DE SÍMBOLOS}

\begin{tabular}{|c|c|}
\hline$K$ & Constante de adsorção \\
\hline$A_{\max }$ & $\begin{array}{l}\text { Máxima quantidade de substância adsorvida de poluente por } \\
\text { grama de carvão }\end{array}$ \\
\hline$C_{0}$ & Concentração inicial do adsorbato \\
\hline$C_{\text {eq }}$ & Concentração do adsorbato no equilíbrio \\
\hline$U$ & Variável \\
\hline$X_{\mathrm{i}}$ & Calor codificado da variável $i$ \\
\hline
\end{tabular}




\section{SUMÁRIO}

1. INTRODUÇÃO E JUSTIFICATIVA .........................................................18

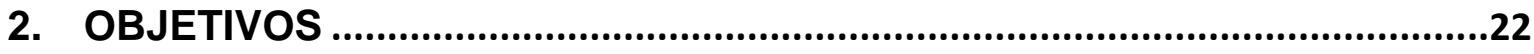

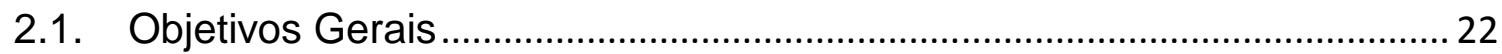

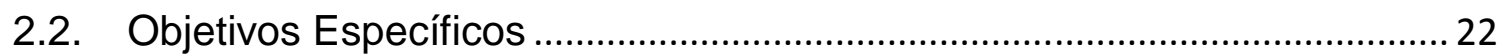

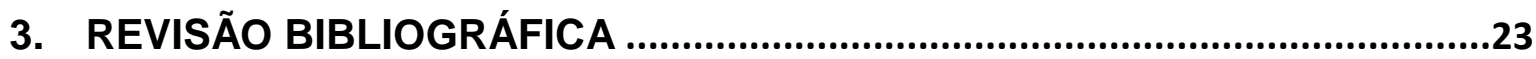

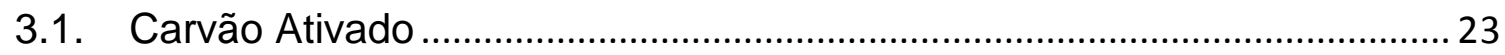

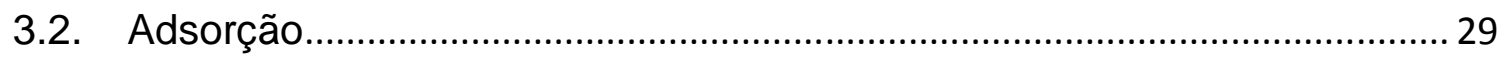

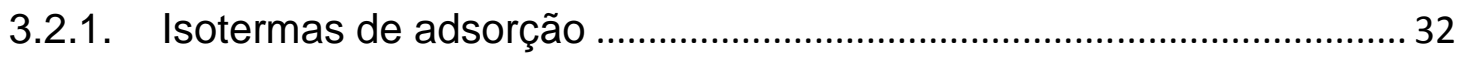

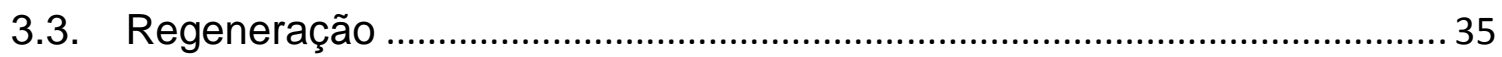

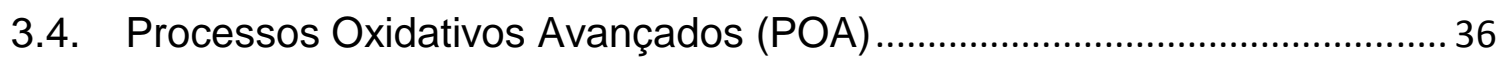

3.4.1. Peroxidação Assistida por Radiação Ultravioleta $\left(\mathrm{H}_{2} \mathrm{O}_{2} / \mathrm{UV}\right)$.............. 38

3.4.2. Peroximonossulfato de Potássio (PMS) ............................................... 39

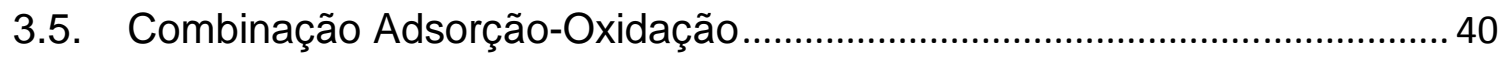

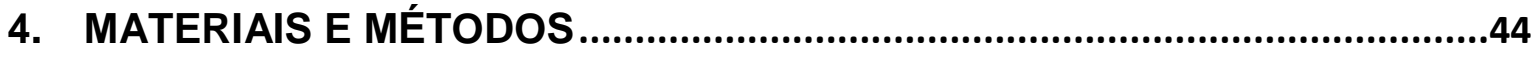

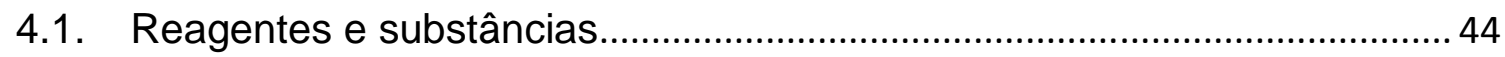

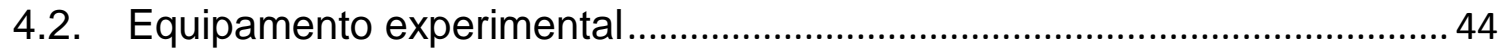

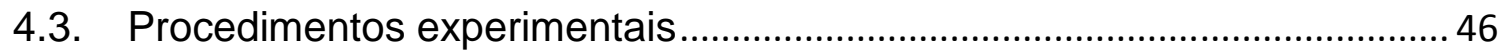

4.3.1. Obtenção de isotermas de adsorção do pesticida no carvão ativado ... 46

4.3.2. Regeneração pelo processo oxidativo $\mathrm{H}_{2} \mathrm{O}_{2} / \mathrm{UV}$................................... 49

4.3.3. Regeneração por peroximonossulfato de potássio (PMS) ...................... 51

4.4. Técnicas analíticas e de medição .............................................................. 52

4.4.1. Cromatografia líquida de alta eficiência (HPLC) com detector UV ........ 52

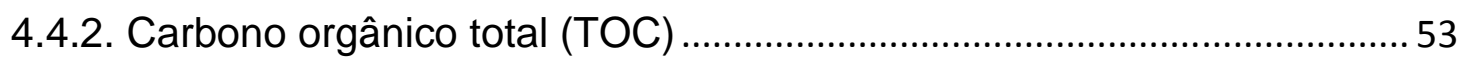




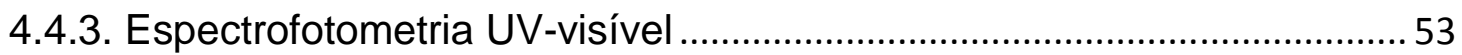

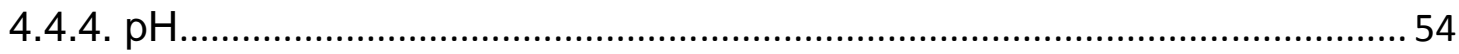

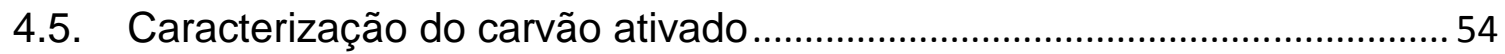

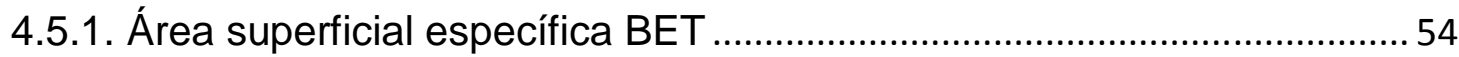

4.5.2. Microscopia eletrônica de varredura (MEV) .............................................. 55



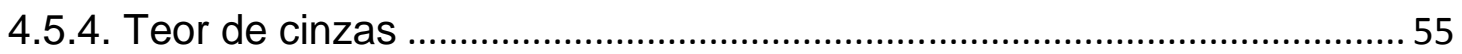

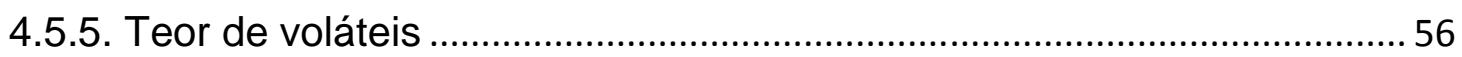

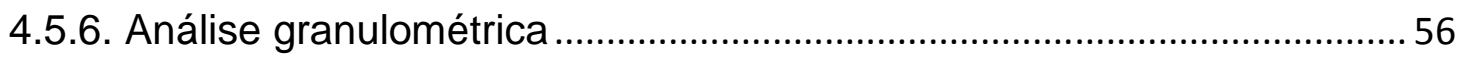

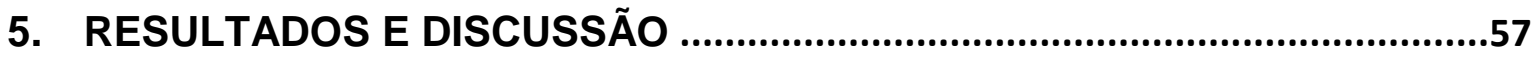

5.1. Caracterização do carvão ativado empregado no trabalho ........................ 57

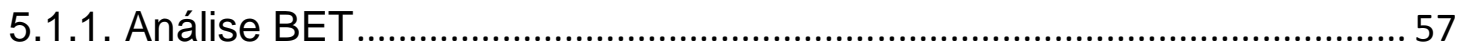

5.1.2. Análise MEV (Microscopia Eletrônica de Varredura) ............................... 58

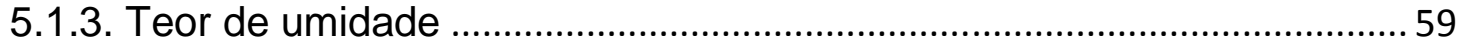

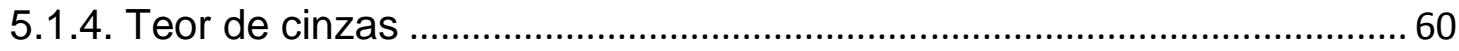

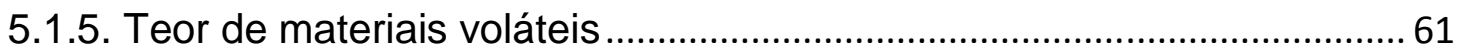

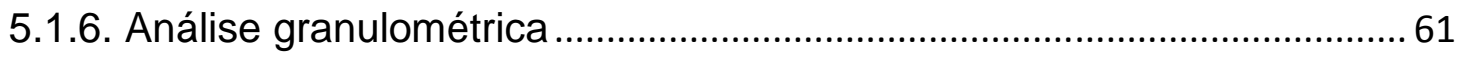

5.2. Análise do efeito da vazão sobre a adsorção............................................ 62

5.3. Estudo da adsorção da amicarbazona no carvão ativado ..........................66

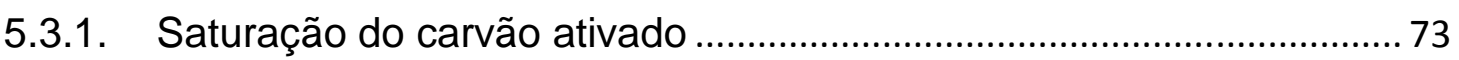

5.4. Regeneração pelo Processo Oxidativo $\mathrm{H}_{2} \mathrm{O}_{2} / \mathrm{UV}$..................................... 74

5.5. Regeneração por peroximonossulfato de potássio (PMS) ......................... 77

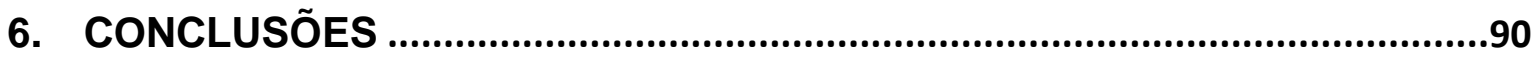

7. REFERÊNCIAS BIBLIOGRÁFICAS .....................................................92 


\section{INTRODUÇÃO E JUSTIFICATIVA}

O solo é um recurso finito e não renovável, podendo levar milhares de anos para tornar-se terra produtiva. De acordo com estimativas recentes, as várias formas de degradação do solo têm levado a perdas de 5 a 7 milhões de hectares de terras cultiváveis por ano. A perda dos solos e o crescimento demográfico, que gera grandes pressões para a produção de maior quantidade de alimentos, têm resultado no desmatamento de áres florestadas para expansão das áreas agriculturáveis (TEIXEIRA et al., 2008). Em vista desses problemas, torna-se necessário o uso de produtos que auxiliem no processo de produção de alimentos, como é o caso dos defensivos agrícolas, já que os alimentos estão cada vez mais caros uma vez que a procura é maior que a oferta. O controle de pragas e de fitopatógenos por meio da aplicação desses produtos ocorre desde antes do século XI (DOMINGUES et al., 2004).

Há grande preocupação ambiental com relação a esses compostos já que podem sofrer processos de bioacumulação em diferentes níveis tróficos (CORBI et al., 2006), e os problemas não se devem exclusivamente aos princípios ativos, mas também podem estar associados aos subprodutos gerados a partir de sua degradação no meio ambiente (SHEMER et al., 2006).

A contaminação ambiental por esses compostos pode ser de origem difusa, devido a perdas na aplicação do produto pela deriva ocasionada pelos ventos e pela evaporação, ou pontual, que provém de processos industriais, da lavagem de tanques de mistura e reatores nas indústrias, da lavagem de equipamentos empregados na aplicação na lavoura e de embalagens vazias, entre outros.

Seu consumo gera um círculo vicioso: quanto mais se usa, maiores são os desequilíbrios provocados e maior a necessidade do uso de doses mais intensas e de formulações cada vez mais tóxicas. Portanto, embora a utilização dos agrotóxicos tenha proporcionado o aumento da produtividade agrícola, o uso indiscriminado desses produtos pode trazer prejuízos à saúde humana, animal e ao meio ambiente (DOMINGUES et al., 2004). A amicarbazona (4-amino-4,5dihidro-N-(1,1-dimetil etil)-3-(1-metil etil)-5-oxo-1H-1,2,4-triazol-1-carboxamida) é um exemplo de herbicida relativamente novo que atua inibindo o transporte de 
elétrons nas folhas, o que significa a rápida translocação do herbicida das raízes para as folhas (DE SÁ, 2010).

Seu uso pode ser em pré- ou pós-aplicação nas lavouras de cana-deaçúcar e de milho e também em combinação com outros herbicidas para ampliar o espectro de ação e eficácia (PHILBROOK et al., 1999; DAYAN et al., 2009). Ainda são poucos os estudos sobre este herbicida na literatura voltados ao efeito sobre as plantas cultivadas, ao controle de ervas daninhas e à dispersão no meio ambiente (SOUZA et al., 2009; BACHEGA et al., 2009) e nenhum a respeito da adsorção do mesmo em carvão ativado.

Nesse contexto, a água é um dos recursos naturais mais prejudicados pela contaminação com pesticidas ou seus resíduos, o que traz preocupação, já que é fundamental para todas as atividades desenvolvidas pelo homem e para os seres vivos (PIVELI; KATO, 2006).

Do total de água existente no planeta apenas 3\% constituem água doce; desses, $68,9 \%$ estão em geleiras, $29,9 \%$ nos subsolos e somente $0,3 \%$ estão disponíveis em lagos e rios (TOMAZ, 2001), o que torna a situação mais preocupante ainda. $O$ uso desenfreado dos recursos hídricos e sua poluição vêm obrigando a adoção de medidas de regulação do uso e muitas vezes modificação dos cursos d'água o que gera variações nos ecossistemas e microclimas, com prejuízos à flora, fauna e habitat (PORTAL, 2011). Por outro lado, nos países em desenvolvimento como o Brasil, são poucas as cidades que contam com estações de tratamento para os esgotos domésticos, agrícolas e indústrias. Segundo dados do IBGE (2008), o Brasil apresenta 3069 municípios com coleta de esgoto, mas só 1587 , ou seja, cerca de $52 \%$, possuem estações de tratamento do esgoto coletado.

Dessa forma, órgãos nacionais e internacionais, como a EPA (Environmental Protection Agency) dos Estados Unidos e a Comunidade Europeia têm proposto limites em relação às concentrações de pesticidas encontrados em água. O Brasil também apresenta uma legislação que regulamenta as concentrações máximas permitidas de pesticidas em água potável: a Portaria do Ministério da Saúde o 518, de 25 de março de 2004, estabelece os padrões de potabilidade para substâncias químicas que representam risco à saúde, entre elas os pesticidas (COSTA et al., 2008). 
Como os tratamentos convencionais de água normalmente não reduzem as concentrações de pesticidas significativamente, torna-se necessário utilizar outros tipos de tratamento associados e uma alternativa que vem crescendo é o uso do carvão ativado, indicado pela EPA (Environmental Protection Agency) para tal finalidade, já que permite remover micropoluentes orgânicos presentes (PAWLOWSKY et al., 1997). Sua viabilidade econômica está associada, porém, ao seu reúso e/ou ao emprego associado a outros processos de tratamento de efluentes aquosos. Por outro lado, como os carvões ativados têm capacidade de adsorção limitada e acumulam contaminantes por vezes com alta toxicidade, acaba-se gerando um resíduo sólido que deve ser tratado ou descartado apropriadamente e, conseqüentemente, seu custo de operação torna-se alto (TRATAMENTO, 2002).

Além disso, com o objetivo de remediar completamente os efluentes mais complexos, uma série de combinações envolvendo dois ou mais processos de tratamento está sendo intensivamente estudada nos últimos anos para o tratamento de efluentes agroquímicos, têxteis, gerados no processo de celulose e papel e nitroaromáticos (MALATO et al., 2002; SARRIA et al., 2003; PARRA, 2001; KUNZ, 1999; MORAES, 1999; PAIVA, 1999; AMAT et al., 2005). A incineração, embora seja um dos procedimentos mais clássicos para a disposição final de carvões ativados, pode levar à formação e ao lançamento na atmosfera de compostos tóxicos, além de apresentar alto custo (FREIRE et al., 2000). Os métodos térmicos de regeneração apresentam várias desvantagens como 0 alto consumo de energia para manter a temperatura acima de $800^{\circ} \mathrm{C}$ e perda de carvão pela combustão (MARTIN; NG, 1987).

Por conta disso, o desenvolvimento de novas técnicas de regeneração de carvão ativado contaminado após uso, como o emprego de Processos Oxidativos Avançados (POA), tem recebido muita atenção. Os POA são caracterizados pela geração de radicais hidroxila $(\mathrm{HO} \bullet)$, que possuem alto potencial padrão de redução, sendo fortes oxidantes e capazes de mineralizar uma vasta gama de substâncias, geralmente sem a necessidade de disposicão final. Assim, eles constituem uma alternativa tecnológica promissora para a remoção dos contaminantes adsorvidos em carvão ativado (OPPENLÄNDER, 2003). 
Nesse contexto, a principal contribuição do presente trabalho consiste no estudo da aplicação dos POA baseados na peroxidação assistida por radiação ultravioleta $\left(\mathrm{H}_{2} \mathrm{O}_{2} / \mathrm{UV}\right)$ e oxidação promovida por peroximonossulfato de potássio (PMS), para regeneração de carvão ativado contaminado com o herbicida amicarbazona. 


\section{OBJETIVOS}

\subsection{Objetivos Gerais}

O objetivo deste trabalho é estudar a regeneração do carvão ativado, empregado na adsorção do pesticida amicarbazona a partir de soluções aquosas, por meio dos Processos Oxidativos Avançados baseados na peroxidação assistida por radiação ultravioleta $\left(\mathrm{H}_{2} \mathrm{O}_{2} / \mathrm{UV}\right)$ e oxidação promovida por peroximonossulfato de potássio (PMS).

\subsection{Objetivos Específicos}

- Estudar a adsorção de amicarbazona em carvões ativados por meio do levantamento de isotermas de adsorção;

- Regenerar o carvão ativado contaminado através dos POA baseados na peroxidação assistida por radiação ultravioleta $\left(\mathrm{H}_{2} \mathrm{O}_{2} / \mathrm{UV}\right)$ e na oxidação promovida por peroximonossulfato de potássio (PMS);

- Avaliar as condições para regeneração por meio de POA em termos das variáveis: concentração do contaminante; $\mathrm{pH}$ e concentração do(s) oxidante(s), à temperatura constante. 


\section{REVISÃO BIBLIOGRÁFICA}

\subsection{Carvão Ativado}

O carvão ativado é um tipo de material carbonáceo que possui área superficial específica e porosidade bastante desenvolvidas, permitindo-Ihe adsorver moléculas de substâncias orgânicas, tanto em fase líquida quanto em fase gasosa (SNOEYINK; WEBER, 1967; LITTRELL et al., 2002). Esse material carbonáceo apresenta forma microcristalina não grafítica e sofre processamento para aumentar a porosidade interna (ativação). No decorrer da ativação, a área superficial aumenta com a oxidação do carbono, podendo atingir valores superiores a $1000 \mathrm{~m}^{2} \mathrm{~g}^{-1}$ (SCHNEIDER, 2008). A utilização dos carvões ativados como adsorventes data de antes de 1600 a.C., quando os egípcios empregavam o carvão de madeira para a purificação de água para fins medicinais. Assim como aconteceu com os pesticidas, os carvões ativados apresentaram maior desenvolvimento durante a $1^{\underline{a}}$ Guerra Mundial, quando o carvão ativado granular (CAG) era utilizado em máscaras de gás (CENDOFANTI, 2005).

Em geral os materiais que podem gerar esse tipo de carvão podem ser madeira, hulha, lignina, casca de coco, grão de café, bambu, quitosana etc. No Brasil, os carvões ativados são produzidos a partir de matérias-primas vegetais tais como cascas de coco (babaçú, dendê, coco da Bahia, macaúba, entre outros), caroço de pêssego, nó de pinho e madeiras em geral (pinus, eucalipto, peroba, acácia, bracatinga, entre outros). A escolha do material a ser ativado dependerá da sua pureza, preço e potencial de ativação (PASTOR-VILLEGAS et al., 1999; BACAOUI, 2001; LAINE et al., 1989; AHMEDNA et al., 2000; SCHNEIDER, 2008).

Além disso, a distribuição dos tamanhos dos poros de um carvão ativado depende do tipo do material e da maneira de ativação do mesmo, o que envolve tratamento térmico com a presença de agentes químicos (por exemplo, ácido sulfúrico) ou pela gaseificação controlada (vapor de água), que é um método 
físico. Esses poros são seções imperfeitas de lamelas de grafite de tamanho reduzido, que são dobradas e possuem vários defeitos estruturais. Elas são ligadas umas às outras, formando uma rede tridimensional, de modo que o espaço entre elas dá origem à porosidade do carvão. Assim, os carvões ativados são obtidos através de duas etapas básicas: a carbonização e a ativação propriamente dita (FERREIRA, 2006; SCHNEIDER, 2008).

A carbonização consiste na pirólise do precursor em atmosfera inerte, a temperatura superior a $700 \mathrm{~K}$. Trata-se, na verdade, de uma etapa de preparação do material, em que se removem componentes voláteis e gases leves $\left(\mathrm{CO}, \mathrm{H}_{2}\right.$, $\mathrm{CO}_{2}$ e $\mathrm{CH}_{4}$ ), produzindo uma massa de carbono fixa e uma estrutura porosa primária que favorece a posterior ativação. Os parâmetros que determinam a qualidade e o rendimento do produto carbonizado são a taxa de aquecimento, a temperatura final, o fluxo de gás de arraste e a natureza do material precursor. Já a etapa ativação consiste em submeter o material carbonizado a reações secundárias, visando ao aumento da área superficial, sendo esta a etapa fundamental na qual é promovido o aumento da porosidade do carvão (CLAUDINO, 2003). Deseja-se nesse processo controlar as características básicas do material (distribuição de poros, área superficial específica, atividade química da superfície e resistência mecânica), de acordo com a configuração requerida para uma dada aplicação (SOUZA, 2010).

São utilizados dois tipos de processo de ativação: ativação química ou física, sendo que os produtos destes dois processos possuem características próprias com relação às interações adsorbato-adsorvente durante a adsorção (CENDOFANTI, 2005).

A ativação física é basicamente um processo de oxidação do carvão. Nela o carvão é ativado mediante gaseificação parcial por $\mathrm{CO}_{2}$ e/ou vapor de água (PASTOR-VILLEGAS et al., 1999) a altas temperaturas, o que faz com que os agentes oxidantes volatilizem os hidrocarbonetos superficiais que foram depositados na superfície do carvão durante o processo de carbonização (CENDOFANTI, 2005). As moléculas de água, por serem menores que as de gás carbônico, têm acesso mais fácil aos microporos, de modo que há penetração das moléculas nos microporos, aumentando o volume dos mesmos e, 
conseqüentemente, aumentando a área superficial do carvão (SCHNEIDER, 2008).

Por outro lado, na ativação química o material a ser ativado é impregnado com substâncias químicas antes da pirólise, tais como o ácido fosfórico, hidróxido de potássio, cloreto de zinco, entre outros. Esse processo pode alterar as características do carvão produzido e resultar em mudança na formação dos mesoporos e macroporos, normalmente proporcionando maior capacidade de adsorção. De modo geral, a estrutura de poros resultante da ativação física torna o carvão produzido desta forma mais apropriado para o uso no processo de adsorção de gases, enquanto que a ativação química gera carvões com poros grandes, os quais são mais apropriados para aplicações de adsorção em fase líquida (FOGLER, 1998).

A área especifica dos carvões após ativação pode variar entre 500 e 3000 $\mathrm{m}^{2} \mathrm{~g}^{-1}$, dependendo do tamanho e da distribuição de poros no material. Esta área superficial interna é desenvolvida durante o processo de produção pela oxidação de matérias voláteis, gerando vazios e formando assim uma rede porosa que auxiliará na retenção da substância a ser adsorvida.

A reação de ativação pode ser catalisada por sais (por exemplo, sais de $\mathrm{Mg}, \mathrm{Ca}$ e $\mathrm{Na}$ ), que podem estar presentes nas cinzas constituintes do produto do processo de carbonização. Ao final desse processo, pode-se fazer o controle da granulometria do produto resultante por moagem, aglomeração ou por classificação usando peneiras. O produto final deve ser lavado para a remoção de constituintes minerais (PÉREZ-FLORINDO et al., 1993).

De acordo com a União Internacional de Química Pura e Aplicada (IUPAC), os carvões ativados possuem poros com diâmetros classificados como macro, meso e microporos (MORENO et al., 2005). A Tabela 1 traz as características associadas a cada um desses tipos de poros.

Os macroporos de um carvão ativado apresentam a desvantagem de apresentar baixa capacidade de adsorção, porém podem atuar como poros de transporte, permitindo a difusão de moléculas do adsorbato até os poros menores no interior das partículas de carvão. Já os mesoporos servem de passagem para os microporos na adsorção, além de atuarem como sítios onde a condensação 
capilar pode ocorrer (CENDOFANTI, 2005). A forma como essa estrutura está distribuída no carvão pode ser observada na Figura 1.

Tabela 1- Classificação dos poros de um carvão ativado (DUBININ, 1979).

\begin{tabular}{cccc}
\hline Classificação & $\begin{array}{c}\text { Diâmetro } \\
\text { nédio dos poros } \\
(\mathbf{n m})\end{array}$ & $\begin{array}{c}\text { Volume } \\
\text { específico de } \\
\text { poros } \\
\left(\mathbf{c m}^{\mathbf{3}} \mathbf{~ g}^{-1}\right)\end{array}$ & $\begin{array}{c}\text { Área superficial } \\
\text { específica } \\
\left(\mathbf{m}^{\mathbf{2}} \mathbf{~ g}^{-1}\right)\end{array}$ \\
\hline Microporos & $<2$ & $0,2-0,6$ & $400-900$ \\
Mesoporos & $2-50$ & $0,02-0,1$ & $20-70$ \\
Macroporos & $>50$ & $0,2-0,8$ & $0,5-2$ \\
\hline
\end{tabular}

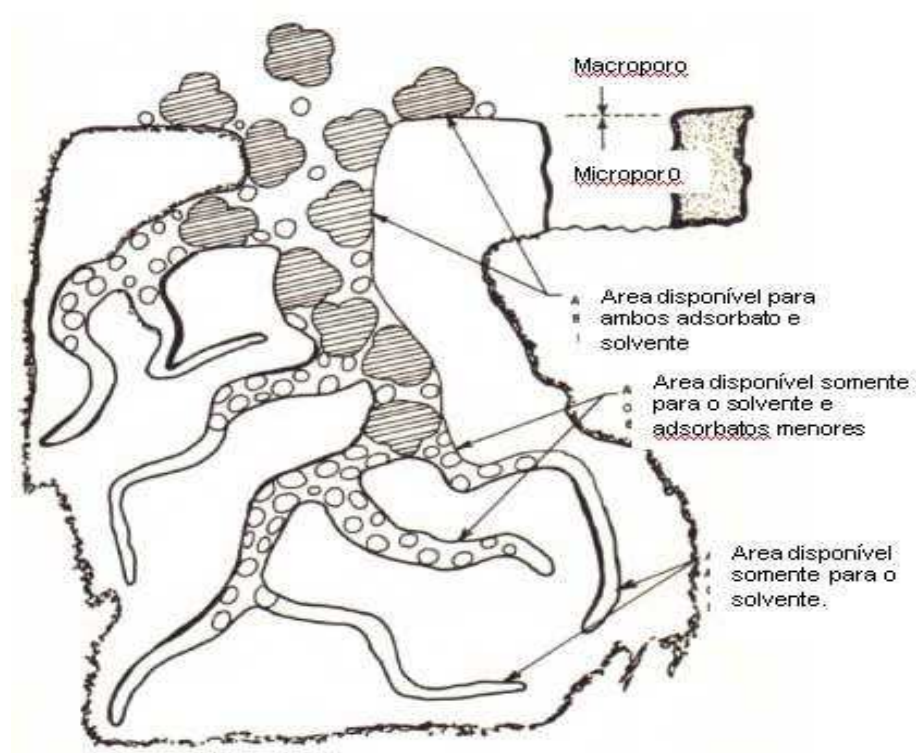

Figura 1- Porosidade em carvões ativados (ALPHACARBO, 2011).

Os microporos por sua vez são de grande importância, já que possuem grande área superficial e conseqüentemente, grande capacidade de adsorção. Eles contribuem com aproximadamente $95 \%$ do total da área superficial específica de um carvão ativado (CENDOFANTI, 2005).

Além dos poros, os carvões podem ter grupos funcionais quimicamente ligados em sua superficie, o que também é importante uma vez que o adsorbato fica retido como conseqüência de interações com as partículas constitutivas do sólido (MEZZARI, 2002). Trata-se de heteroátomos como oxigênio e hidrogênio, 
além de componentes inorgânicos, como observado na Figura 2 (SCHNEIDER, 2008).

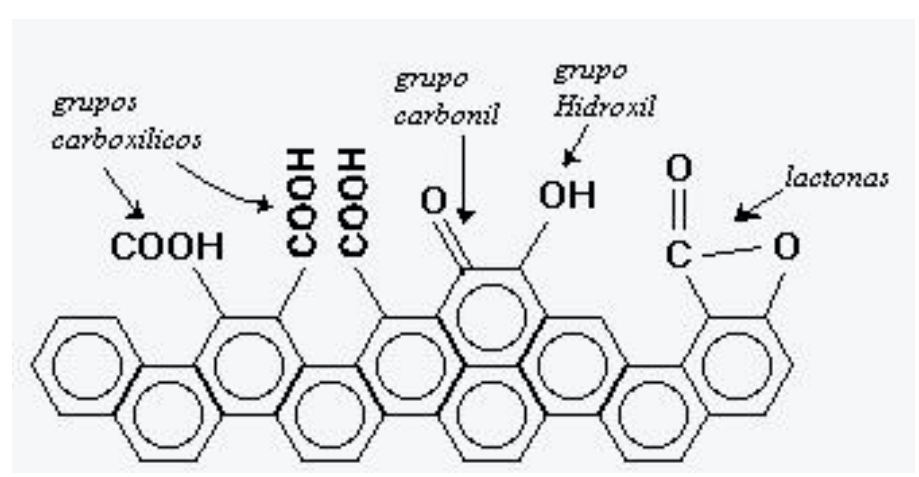

Figura 2 - Grupos funcionais encontrados na superfície dos carvões (CARVÃO, 2012).

Os ácidos, que estão associados à superfícies com grandes quantidades de oxigênio, possuem a propriedade de troca de ânions ao passo que superfícies com baixas quantidades de oxigênio são responsáveis por características básicas e efetuam trocas de cátions (SCHNEIDER, 2008). Assim, o carvão ativado apresenta superficies heterogêneas, que advêm de sua natureza estrutural, resultante da diferença de tamanho e formato dos poros; e de sua natureza química, relacionadas com os diferentes grupos funcionais, o que contribui para as suas diferentes propriedades de adsorção (DABROWSKI et al., 2005).

Além das classificações anteriores, os carvões ativados (CA) podem ser classificados como pulverizados (CAP) ou granulados (CAG). Os primeiros são comercializados na forma de pó, sendo empregados no tratamento em meio líquido e indicados quando dosagens variadas são requeridas, pois são versáteis e podem ser utilizados em equipamentos como tanques, filtros e misturadores em uma mesma unidade e para diferentes produtos (AREND et al., 2006). Já os CAG possuem maior tamanho médio de partícula, sendo utilizados tanto para correntes líquidas quanto para correntes gasosas. Eles são indicados quando se deseja trabalhar em coluna, além de terem como vantagem o fato de poderem ser regenerados, serem de fácil manejo e re-utilizados (CENDOFANTI, 2005). Uma das principais limitações da utilização de CAG é a necessidade de troca periódica do leito filtrante, uma vez que os tempos de vida do leito para a remoção de substâncias orgânicas são geralmente curtos e a regeneração deve ser frequente 
(SOUZA, 2010). Esses dois tipos de carvões ativados encontram grande aplicação industrial (CENDOFANTI, 2005), como:

- No tratamento de água, adsorvendo compostos orgânicos, como detergentes, pesticidas, hidrocarbonetos poliaromáticos e traços de metais, sendo muito empregados para retirar cor e odor da água;

- Na indústria alimentícia;

- Para recuperar ouro na forma $\mathrm{Au}(\mathrm{CON})^{-2}$ a partir de seus minérios;

- Na recuperação de solventes, adsorvendo vapores orgânicos, em processos envolvendo tintas, adesivos, polímeros e explosivos;

- Em filtros de proteção, utilizados nas áreas industrial, nuclear e militar, já que adsorvem bem hidrogênio, fosfina, iodo radioativo, xenônio, entre outros poluentes;

- Nos condicionadores de ar, como purificadores;

- Ainda, no campo medicinal, são utilizados no tratamento de envenenamento e overdoses.

O emprego na remoção de contaminantes do meio aquoso merece destaque especial já que cada vez mais há aumento na complexidade dos componentes indesejáveis presentes nos efluentes aquosos (RAMOS et al., 2009).

Para garantir maior eficiência do processo de adsorção, deve-se assegurar que o carvão, quando operado em coluna, permaneça em contato com o meio contendo o adsorbato por tempo suficiente. Além disso, é necessário controlar a vazão do meio contaminado percolante, para que não fique acima do valor especificado para o projeto, o que poderia acarretar o revolvimento inadequado do leito, favorecendo a formação de caminhos preferenciais, prejudicando o desempenho do sistema (CENDOFANTI, 2005). 


\subsection{Adsorção}

A adsorção representa uma das operações unitárias mais empregadas nas unidades de tratamento de efluentes industriais por representar um processo de baixo custo e de fácil operação. É um processo de transferência de massa envolvendo um sistema sólido-fluido (RUTHVEN, 1984), que acontece em uma superfície sólida que, quando em contato com uma solução, tem a tendência a acumular uma camada superficial de moléculas de soluto (adsorbato) o que permite separá-las dos demais componentes dessas soluções. A adsorção é geralmente utilizada na remoção de compostos orgânicos refratários presentes em muitos efluentes industriais e cuja remoção se torna difícil ou impossível por processos de tratamentos biológicos convencionais, sendo uma excelente alternativa como pré-tratamento ou quando utilizado em conjunto com outra técnica de tratamento de efluentes (TRATAMENTO, 2002). São três as etapas que compõem esse processo (MURANAKA, 2010):

1) Macrotransporte: que é o movimento do material orgânico através do sistema macroporoso do carvão ativado;

2) Microtransporte: que é o movimento do material orgânico através do sistema mesoporoso e microporoso do carvão ativado;

3) Sorção: que é o "aprisionamento" físico do material orgânico na superfície do carvão ativado, nos mesoporos e nos microporos.

O processo de adsorção pode ser físico ou químico, de acordo com a natureza das interações produzidas entre o material adsorvido e a superfície do adsorvente. $\mathrm{Na}$ adsorção física (ou fisissorção) as moléculas de um fluido se concentram espontaneamente sobre uma superfície sólida, sem que haja uma reação química. Nela atinge-se rapidamente o equilíbrio, sendo por isso classificada como reversível. Além disso, ela ocorre por uma diferença de energia e/ou forças de atração, as forças de van der Waals (RUTHVEN, 1984). A reversibilidade deste tipo de adsorção depende das forças atrativas entre o 
adsorbato e o adsorvente; se estas forem fracas, a dessorção ocorre com certa facilidade (CENDOFANTI, 2005).

Já na adsorção química (ou quimissorção) ocorre transformação química da molécula adsorvida, com altos valores de entalpia e nem sempre reversível, já que corresponde a uma interação química. Além disso, as ligações são mais fortes e, conseqüentemente, mais energia é necessária para reverter o processo. Este tipo de adsorção prevalece na catálise heterogênea, entretanto, mesmo neste caso, a adsorção física é útil, sendo empregada para determinar as propriedades dos catalisadores ou sólidos adsorventes (volume, tamanho, distribuição dos poros e área superfícial) (GOMIDE, 1980).

A capacidade de adsorção de um composto é incrementada com o aumento da massa molar, com o número de grupos funcionais (como compostos com duplas ligações ou compostos halogênicos) e aumento da polaridade da molécula (SOUZA, 2010). Existem diversos adsorventes comerciais (Tabela 2), sendo que um dos mais utilizados é o carvão ativado. A Tabela 3 traz uma análise comparativa entre os diferentes adsorventes comerciais.

Tabela 2 - Materiais adsorventes e suas aplicações (SANTIAGO et al., 2005).

\begin{tabular}{cc}
\hline Adsorvente & Aplicação \\
\hline Sílica gel & $\begin{array}{c}\text { Purificação de gases, remoção de umidade, } \\
\text { refino de derivados de petróleo }\end{array}$ \\
Carvão ativado & $\begin{array}{c}\text { Adsorção de orgânicos, gases, purificação de } \\
\text { água }\end{array}$ \\
Polímeros & Adsorção de solutos polares em soluções \\
Alumina ativada & Remoção de contaminantes, desidratação de \\
& gases e líquidos
\end{tabular}


Tabela 3 - Análise comparativa de diferentes adsorventes comerciais (SANTIAGO et al., 2005).

\begin{tabular}{lcc}
\hline Adsorvente & $\begin{array}{c}\text { Área superficial } \\
\text { específica }\left(\mathbf{m}^{\mathbf{2}} \mathbf{~ g}^{-\mathbf{1}} \mathbf{)}\right.\end{array}$ & $\begin{array}{c}\text { Diâmetro de poros } \\
(\mathbf{A})\end{array}$ \\
\hline Carvão ativado & $600-1200$ & $20-5000$ \\
Sílica gel & $600-800$ & $20-50$ \\
Alumina & $200-500$ & $20-140$ \\
ativada & & \\
\hline
\end{tabular}

Por outro lado, nem sempre um adsorvente que possui grande área superficial específica mostra-se eficiente na remoção de um dado poluente, pois adsorventes com grandes áreas superficiais são formados basicamente por microporos, que não são diretamente acessíveis da superfície, tornando a adsorção mais difícil do que se houvesse mesoporos intermediando o caminho a ser percorrido pelo adsorbato. Além disso, a velocidade de adsorção torna-se mais elevada com a presença de poros na faixa de mesoporos devido à estrutura mais aberta dos mesmos, facilitando a entrada do adsorbato até os sítios de adsorção. A eficiência de remoção de um dado composto químico pelo adsorvente depende de vários fatores, como tipo e concentração de composto a ser removido, presença de outros compostos orgânicos que podem competir pelos sítios de adsorção disponíveis, $\mathrm{pH}$ da solução, a disponibilidade de oxigênio na solução, área superficial do adsorvente e o volume dos poros. No caso do carvão ativado, cada tipo de poro desempenha um papel particular no fenômeno de adsorção e os microporos são de fundamental importância nesse processo (MEZZARI, 2002; MURANAKA, 2010).

Como o carvão ativado possui capacidade de adsorção limitada é necessário, para que o processo seja contínuo, a instalação de pelo menos dois vasos (leitos) contendo carvão ativado, revezando entre os modos de adsorção e regeneração ou dessorsão. Neste processo busca-se, naturalmente, minimizar a relação custo/beneficio (ASSUNÇÃO, 2003; ROCHA, 2006).

As principais vantagens da adsorção em carvão ativado, em relação aos outros processos de tratamento são a alta eficiência na adsorção de um amplo número de compostos e para uma ampla faixa de concentrações e, usualmente, 
não há a formação de compostos adicionais. Porém há desvantagens como o destino final a ser dado ao carvão e, conseqüentemente, ao contaminante, além de requerer tratamento da água residual. Além disso, a presença de matéria orgânica natural pode influenciar negativamente na remoção do poluente pelo carvão, pois atua competitivamente com os compostos orgânicos alvo, reduzindo a capacidade de remoção destes compostos sobre o carvão (ASSUNÇÃO, 2003).

A composição química superficial do carvão também influencia sua capacidade de adsorção, sendo que os grupos químicos presentes na superfície do carvão são conseqüência do método de ativação sofrido pelo mesmo. $\mathrm{Na}$ maioria dos casos, existem grandes quantidades de outros elementos além do carbono na superfície, como oxigênio, hidrogênio, nitrogênio, fósforo e enxofre. Estes elementos são derivados do material que compõe o carvão e são quimicamente ligados à superfície do mesmo durante o processo de síntese (PRADHAN; SANDLE, 1999).

\subsubsection{Isotermas de adsorção}

A adsorção é normalmente avaliada através de curvas que relacionam a capacidade de adsorção e a concentração do adsorbato. Estas curvas, elaboradas a temperatura constante, são denominadas isotermas de adsorção. A partir de uma isoterma pode-se prever a quantidade de carvão ativado necessária para a retirada total ou parcial de uma substância (adsorbato) de um meio (CALGON, 2007), sendo este o método mais utilizado para descrever os estados de equilíbrio de um sistema, além de fornecer informações úteis para o processo.

A isoterma de adsorção é a relação, a temperatura constante, entre a quantidade adsorvida e a concentração do adsorbato, ou seja, ela representa a quantidade de um determinado soluto adsorvido por uma superfície adsorvente, em função da concentração de equilíbrio do soluto (TAGLIAFERRO et al., 2011). Somente a concentrações muito baixas é que a quantidade adsorvida é proporcional à concentração. É possível obter experimentalmente isotermas e é sua determinação que permite admitir hipóteses sobre o modo de adsorção de um 
dado adsorvente. Para se construir uma isoterma de adsorção coloca-se em contato a solução contendo o componente a ser adsorvido em diferentes concentrações iniciais e em temperatura constante até o equilíbrio, determinandose assim a quantidade de material adsorvido (TAGLIAFERRO et al., 2011).

A literatura registra muitos tipos possíveis de isotermas para diversos tipos de adsorventes e gases, porém Brunauer classificou-as em cinco formas diferentes, sendo que cada tipo de isoterma está relacionado ao tipo de poro envolvido (Figura 3).
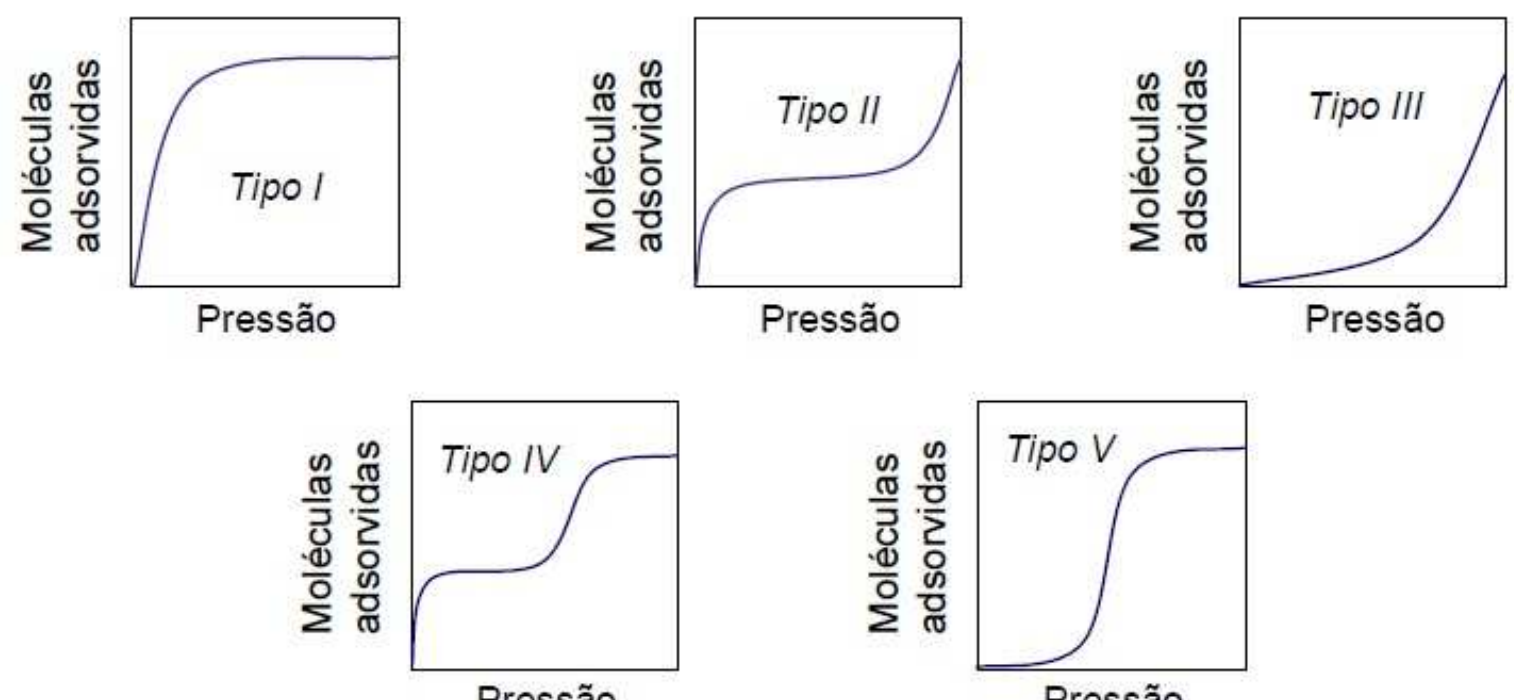

Figura 3 - Esboço dos cinco tipos de isotermas de adsorção segundo Brunauer (BRUNAUER, 2011).

$\mathrm{Na}$ isoterma do tipo I, que está relacionada à adsorção em microporos, o adsorbato cobre o adsorvente, o qual possui uma superficie uniforme, até que há a formação de uma monocamada correspondente ao plateau, ou seja, existe uma saturação limite correspondente ao enchimento completo dos microporos. Este tipo de isoterma se ajusta à isoterma descrita por Langmuir (ATKINS, 2001) e é baseada em quatro hipóteses:

1. A superfície do adsorvente é uniforme, consequentemente todos os sitios de adsorção são iguais; 
2. As moléculas adsorvidas não interagem entre si;

3. Toda a adsorção ocorre através do mesmo mecanismo;

4. Na adsorção máxima, somente uma monocamada é formada, ou seja, as moléculas do adsorbato não depositam em outras moléculas já adsorvidas, somente na superfície livre do adsorvente.

Para determinar a constante de adsorção $(k)$ e a máxima quantidade de substância adsorvida de poluente por grama de carvão $\left(A_{\max }\right)$, segundo a isoterma de Langmuir, deve-se primeiramente determinar a quantidade de substância adsorvida por grama de carvão, segundo a Equação 1.

$$
q_{\mathrm{eq}}=\left(C_{0}-C_{\mathrm{eq}}\right) V / m
$$

em que $C_{0}$ é a concentração inicial do adsorbato; $C_{\text {eq }}$, sua concentração no equilíbrio; $V$ é o volume da solução contendo a substância a ser adsorvida e $m$, a massa de carvão ativado em contato com essa solução. Utiliza-se Equação 2.

$$
\left(q_{\mathrm{eq}}\right)^{-1}=\left(A_{\max } k\right)^{-1} \cdot C_{\mathrm{eq}}^{-1}+\left(A_{\mathrm{max}}\right)^{-1}
$$

em que $\left(q_{\text {eq }}\right)^{-1}=\mathrm{f}\left(C_{\text {eq }}\right)^{-1}$ deve ser uma relação linear. Assim, pode-se calcular $A_{\max }$ e $k$ através dos coeficientes angular e linear da reta obtida, respectivamente.

As isotermas do tipo II e III estão relacionadas à adsorção em sistemas que apresentam uma grande faixa de tamanho de poros, existindo a formação de multicamadas. $\mathrm{Na}$ isoterma do tipo IV, a presença de dois patamares resulta da formação de duas camadas sucessivas de adsorbato na superficie do sólido, quando as interações entre as moléculas e a superfície são mais fortes que entre as interações das moléculas. Já se os efeitos de atração intermolecular são grandes, observa-se a isoterma do tipo V (RUTHVEN, 1984).

Recentemente, Ignatowicz (2011) analisou o modelo de transferência de massa para a adsorção de pesticida em carvão ativado proveniente da casca do coco, o qual se mostrou adequado para esta finalidade. Além disso, a partir da elaboração de isotermas de adsorção, o autor concluiu que os pesticidas 
organoclorados estudados eram adsorvidos como uma monocamada e, consequentemente, não havia competição entre as moléculas do pesticida e as da água para ocupar os sitios de adsorção da superficie. Já Jusoh et al. (2010) compararam o desempenho de dois tipos de carvões ativados granular (provenientes de matérias primas distintas), para a remoção de pesticida do meio ambiente. Salman et al. (2011) estudaram a adsorção dos pesticidas ácido 2,4diclorofenoxiacético (2,4-D) e bentazon, presentes em solução aquosa, através de carvão ativado obtido a partir de caule da bananeira, o qual se mostrou um adsorvente eficiente. Por fim, Gupta et al. (2011) estudaram a remoção de pesticidas de efluentes aquosos através da adsorção por carvão ativado preparado a partir da borracha de pneu, cuja obtenção é mais barata quando comparada à dos carvões ativados comerciais, além de apresentar melhor eficiência de remoção para pesticidas com relação a outros adsorventes reportados na literatura. Outros trabalhos foram propostos por Zhang et al. (2007), Morlay (2012), Ignatowicz (2011), Huling et al. (2011) e Kania et al. (2012).

\subsection{Regeneração}

A adsorção em carvão ativado é um processo de fácil operação, eficiente e relativamente de baixo custo. Um problema associado ao seu uso é a geração de rejeito sólido contaminado que deve ser tratado ou descartado apropriadamente (INCE; APIKYAN, 2000; TRATAMENTO, 2002).

A forma mais simples de reduzir os custos de operação desse processo e eliminar o problema de descarte consistiria em dessover as substâncias nele retidas, reutilizando o carvão ativado. Como nem sempre isso é possível ou eficiente, há grande interesse quanto ao desenvolvimento de técnicas de regeneração, processo utilizado para recuperar a capacidade de adsorção do carvão através da remoção dos materiais adsorvidos nos poros (AREND et al., 2006). Alguns exemplos são: tratamento biológico, extração com solvente, regeneração térmica e oxidação via úmida. No entanto, todas estas tecnologias apresentam várias limitações técnicas e econômicas (MEZZARI, 2002). 
A regeneração térmica, por exemplo, envolve altas temperaturas, entre 700 e $1000^{\circ} \mathrm{C}$, e por isso este processo não é conduzido in situ, requerendo unidades de regeneração especiais. Além de não ser economicamente viável para pequena escala de tratamento, a regeneração térmica resulta em perda de 5 a $15 \%$ por ciclo na capacidade de adsorção e na área superficial, podendo a capacidade de adsorção chegar a zero após alguns ciclos (HARRIOTT; CHENG, 1988; SHEINTUCH; MEYTAL, 1999).

Já os processos de regeneração através da extração com solvente têm se tornado custosos e ambientalmente pouco aceitáveis, uma vez que esses métodos apenas transferem o contaminante do carvão adsorvente para outro composto (solvente), que deverá ser posteriormente tratado. Outra desvantagem deste processo é que a capacidade de adsorção dos carvões regenerados com a extração diminui cerca de 50\% (MEZZARI, 2002).

Outro exemplo é a oxidação via úmida (wet air oxidation), método muito dispendioso, já que envolve equipamentos operando a pressões e temperaturas muito altas. Essa técnica permite aumento no conteúdo de oxigênio na superfície do carvão regenerado, o que sempre implica a diminuição da capacidade de adsorção do carvão para compostos aromáticos (SHEINTUCH; MEYTAL, 1999).

\subsection{Processos Oxidativos Avançados (POA)}

Os Processos Oxidativos Avançados (POA) são definidos, de forma geral, como os processos de oxidação em fase aquosa que se baseiam principalmente no uso de radicais hidroxila $(\mathrm{HO} \cdot)$. Esses radicais possuem potencial padrão de redução de 2,8 $\vee(E P H)$, superior ao de outras espécies oxidantes (Tabela 4), sendo capazes de mineralizar uma grande variedade de compostos orgânicos em efluentes além de diversas espécies inorgânicas. No caso da mineralização total, os produtos finais formados são dióxido de carbono, água e dependendo da composição química do contaminante, cloretos, nitratos, sulfatos e fostatos inorgânicos. O radical hidroxila apresenta baixa seletividade quanto ao ataque a espécies orgânicas, possibilitando a degradação de um grande número de 
contaminantes em tempos relativamente curtos (OPPENLÄNDER, 2003; ANIPSTAKIS, 2005).

Tabela 4 - Potencial padrão de redução de diferentes oxidantes (ATKINS; JONES, 2001).

\begin{tabular}{cc}
\hline Agente oxidante & $\begin{array}{c}\text { Potencial padrão de } \\
\text { redução (V EPH) }\end{array}$ \\
\hline Flúor $\left(\mathrm{F}_{2}\right)$ & 3,03 \\
Radical hidroxila $(\mathrm{HO} \bullet)$ & 2,80 \\
Oxigênio atômico & 2,42 \\
Ozônio $\left(\mathrm{O}_{3}\right)$ & 2,07 \\
Peróxido de hidrogênio & 1,78 \\
$\left(\mathrm{H}_{2} \mathrm{O}_{2}\right)$ & \\
Radical peridroxil $\left(\mathrm{HO}_{2} \cdot\right)$ & 1,70 \\
\hline
\end{tabular}

Os POA mais conhecidos utilizam ozônio $\left(\mathrm{O}_{3}\right)$, radiação ultravioleta (UV), peróxido de hidrogênio $\left(\mathrm{H}_{2} \mathrm{O}_{2}\right)$, reagente de Fenton $\left(\mathrm{Fe}^{2+}\right.$ e $\left.\mathrm{H}_{2} \mathrm{O}_{2}\right)$ e fotocatálise baseada em dióxido de titânio $\left(\mathrm{TiO}_{2}\right)$, os quais dividem-se em sistemas homogêneos e heterogêneos, em que os radicais $\mathrm{HO}$ - podem ser gerados com ou sem o emprego de radiação ultravioleta (ESPLUGAS et al., 2002).

Os sistemas heterogêneos geralmente utilizam semicondutores sólidos (OPPENLÄNDER, 2003). Todos esses processos têm em comum o uso de radicais hidroxila atacando as moléculas orgânicas pela abstração de um átomo de hidrogênio ou por adição às duplas ligações ou a anéis aromáticos. $O$ mecanismo mais aceito para a degradação de um composto orgânico genérico (R) pelo radical hidroxila pode ser representado de acordo com as Equações 3 a 6:

$$
\begin{aligned}
& \mathrm{HO} \cdot+\mathrm{RH} \rightarrow \mathrm{H}_{2} \mathrm{O}+\mathrm{R} \cdot \\
& \mathrm{R} \cdot+\mathrm{H}_{2} \mathrm{O}_{2} \rightarrow \mathrm{ROH}+\mathrm{HO} \cdot \\
& \mathrm{R} \bullet+\mathrm{O}_{2} \rightarrow \mathrm{ROO} \bullet \\
& \mathrm{ROO} \cdot+\mathrm{RH} \rightarrow \mathrm{ROOH}+\mathrm{R} \cdot
\end{aligned}
$$

A elevada eficiência destes processos pode ser atribuída a fatores termodinâmicos, representados pelo elevado potencial de redução do radical 
hidroxila, e cinéticos, favorecidos pela elevada velocidade das reações radicalares (OPPENLÄNDER, 2003). Assim, suas principais vantagens são (MORAIS, 2005; AMORIM et al., 2009):

- Alta capacidade para a mineralização total dos poluentes orgânicos a $\mathrm{CO}_{2}, \mathrm{H}_{2} \mathrm{O}$ e outras espécies inorgânicas;

- Viabilizam a degradação de substratos de qualquer natureza química, como compostos aromáticos halogenados formados durante desinfecção convencional;

- São aplicáveis para tratamento de contaminantes em baixas concentrações;

- Com exceção de alguns processos que podem envolver precipitação (óxidos férricos, por exemplo), os POA geram poucos resíduos, o que reduz a necessidade ou evita a execução de processos complementares de tratamento e disposição;

- Podem ser combinados com outros processos, diminuindo o custo total do tratamento;

- Não há transferência de fase do poluente;

- Podem ser realizados a temperatura e pressão ambiente.

A eficiência dos POA é fortemente influenciada pela qualidade do efluente a ser tratado. Por exemplo, concentrações altas de espécies sequestradores de radicais hidroxila, como carbonato, bicarbonato e íon cloreto, também reduzem a eficiência do tratamento (CRISTINO, 2006). Embora os processos oxidativos apresentem significativas vantagens sobre os métodos convencionais de tratamento, um dos obstáculos para a aplicação dos POA em larga escala é atribuído ao elevado custo dos reagentes e ao custo operacional das fontes radiantes (lâmpadas), no caso de processos foto-oxidativos (ALMEIDA, 2004).

\subsubsection{Peroxidação Assistida por Radiação Ultravioleta $\left(\mathrm{H}_{2} \mathrm{O}_{2} / \mathrm{UV}\right)$}

O peróxido de hidrogênio $\left(\mathrm{H}_{2} \mathrm{O}_{2}\right)$ é um agente oxidante forte e seu uso possui inúmeras vantagens sobre outros tratamentos químicos já que é disponível 
comercialmente, possui estabilidade térmica, pode ser estocado on-site, apresenta solubilidade infinita em água e não gera subprodutos a partir da reação de desinfecção, como organoclorados, por exemplo.

O mecanismo de ação do peróxido de hidrogênio sobre a oxidação dos poluentes orgânicos é baseado na formação de radicais $\mathrm{HO}$ • proveniente da sua decomposição e posterior ação desses radicais sobre a matéria orgânica poluente (R) segundo as reações dadas pelas Equações 7, 8 e 9 (MINATO, 2010):

$$
\begin{aligned}
& \mathrm{H}_{2} \mathrm{O}_{2} \rightarrow 2 \mathrm{HO} \cdot \\
& \mathrm{HO} \cdot+\mathrm{R}-\mathrm{H} \rightarrow \mathrm{R} \bullet+\mathrm{H}_{2} \mathrm{O} \\
& \mathrm{R} \bullet+\mathrm{HO} \cdot \rightarrow \mathrm{ROH}
\end{aligned}
$$

A Tabela 5 apresenta algumas vantagens e desvantagens do processo

\begin{tabular}{|c|c|}
\hline Vantagens & Desvantagens \\
\hline $\begin{array}{c}\text { Elevada solubilidade do } \mathrm{H}_{2} \mathrm{O}_{2} \mathrm{em} \\
\text { água }\end{array}$ & Custo do processo \\
\hline Sistema homogêneo & $\begin{array}{c}\mathrm{H}_{2} \mathrm{O}_{2} \text { também reage com radicais } \\
\text { hidroxila }\end{array}$ \\
\hline Estabilidade térmica & Taxa de oxidação química do poluente é \\
\hline Procedimentos e operações & limitada pela taxa de formação dos \\
\hline simples & radicais hidroxila \\
\hline
\end{tabular}
$\mathrm{H}_{2} \mathrm{O}_{2} / \mathrm{UV}$ (SOUZA, 2010).

Tabela 5 - Vantagens e desvantagens do processo $\mathrm{H}_{2} \mathrm{O}_{2} / U V$ (SOUZA, 2010).

\subsubsection{Peroximonossulfato de Potássio (PMS)}

Outro bom oxidante é o peroximonossulfato de potássio (PMS). Este vem sendo pesquisado recentemente e tem mostrado excelentes resultados com relação ao aumento das taxas de degradação de diferentes contaminantes 
orgânicos e remoção de carbono orgânico, pois são considerados melhores receptores de elétrons que oxigênio molecular (ANIPSITAKIS, 2005).

O peroximonossulfato de potássio tem fórmula molecular $2 \mathrm{KHSO}_{5} \cdot \mathrm{KHSO}_{4} \cdot \mathrm{K}_{2} \mathrm{SO}_{4}$, e sua ativação, que pode ser catalitica, térmica ou fotolítica, forma radicais sulfatil $\left(\mathrm{SO}_{4}{ }^{\circ}\right)$, poderosos oxidantes capazes de destruir muitos contaminantes orgânicos presentes em sítios contaminados (FILHO et al., 2007). Os mecanismos de ação destes radicais ainda não são completamente compreendidos. O PMS é comercializado como Oxone, amplamente utilizado como oxidante para tratamento de água de piscinas e em spas.

A ativação de oxidante PMS por radiação UV resulta na clivagem homolítica da ligação peróxido e na formação de radicais $\mathrm{SO}_{4}{ }^{*}$ e $\mathrm{HO} \cdot$ (Equação 10) (ANTONIOU; CRUZ; DIONYSIOU, 2010).
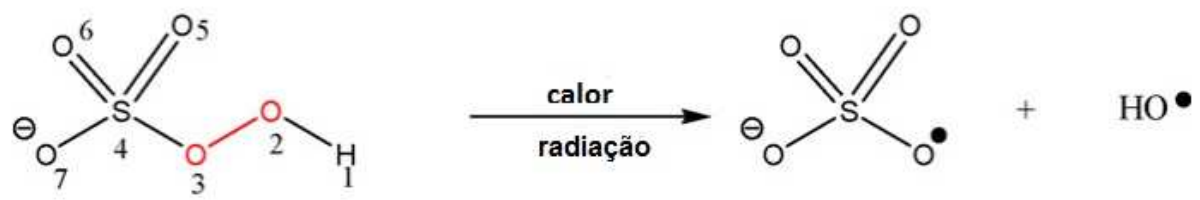

Porém a grande maioria dos estudos se concentra no uso de cobalto, ou outros metais de transição, para a ativação de PMS, em associação ou não com radiação UV com o objetivo de tratar os contaminantes recalcitrantes em água. $O$ uso do peroximonossulfato de potássio, sem ativação por cobalto ou outro metal de transição como alternativa como aceptor de elétrons, ainda não tem sido muito investigado para aplicações ambientais (ANIPSTAKIS; DIONYSIOU, 2004).

\subsection{Combinação Adsorção-Oxidação}

Muranaka (2010) estudou a regeneração de carvão ativado contaminado com fenol pelos processos Fenton e foto-Fenton e concluiu que ambos são aplicáveis para essa finalidade. A autora também concluiu que uma maior 
quantidade de peróxido de hidrogênio contribuiu para a oxidação do carvão ativado, mudando sua superficie ativa e seu tamanho de poros, provocando a diminuição da eficiência do mesmo após sucessivas regenerações.

Alvarez et al. (2009) investigaram a regeneração de carvão por ozonização, compreendendo a etapa de adsorção e posterior regeneração com ozônio gasoso. Os experimentos, que foram conduzidos em um sistema contínuo, apresentaram $90 \%$ de eficiência de regeneração, sendo que a capacidade de adsorção do carvão diminuiu progressivamente, de acordo com o número de ciclos de regeneração, devido à destruição da porosidade superficial e sua oxidação devido à ação do ozônio na superficie do CAG (carvão ativado granular).

Mourand et al. (1995) estudaram dois POA para a regeneração de carvão ativado: $\mathrm{H}_{2} \mathrm{O}_{2} / \mathrm{O}_{3}$ e $\mathrm{H}_{2} \mathrm{O}_{2} / \mathrm{UV}$. Os processos foram avaliados de acordo com a eficiência de destruição, taxa de regeneração e a quantidade de oxidantes consumidos. Este estudo sugeriu que a regeneração de adsorventes por processos oxidativos avançados homogêneos não seria prática, já que consome mais oxidante do que seria requerido para a simples destruição dos contaminantes orgânicos. Por sua vez Dabek e Swiatkowski (2009) apresentam uma revisão com 41 referências de processos utilizados para a regeneração de carvão, como Fenton, $\mathrm{H}_{2} \mathrm{O}_{2}$ e $\mathrm{O}_{3}$.

São dois os modos de operação principais do processo combinado entre adsorção e oxidação catalítica:

1) O processo simultâneo de adsorção e oxidação de contaminantes;

2) $O$ processo em duas etapas que consiste primeiro em passar o efluente contaminado pela etapa de adsorção em carvão ativado até saturação deste, após o que segue a etapa de tratamento do carvão por processo oxidativo. Tem-se assim um ciclo adsorção-oxidação e, ao final deste, obtém-se o carvão ativado regenerado, que pode ser reutilizado no tratamento de efluentes, iniciando-se um novo ciclo. Este processo é o que será o tratado no presente trabalho e está representado na Figura 4. 


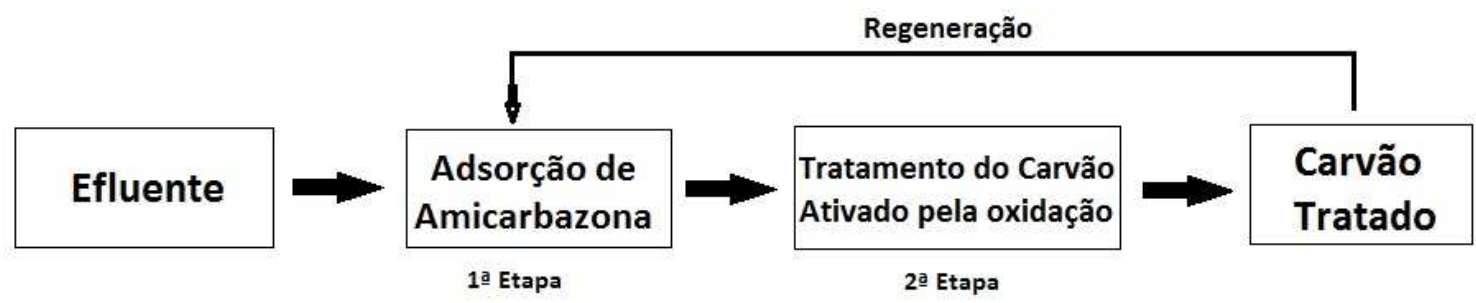

Figura 4 - Ciclo da combinação adsorção-oxidação.

As vantagens de se combinar a adsorção com a oxidação são a possibilidade de tratar grandes volumes de efluente e permitir a pré-concentração do poluente no carvão ativado, sendo possível obter água livre de contaminantes orgânicos, ocorrendo destruição do poluente e a regeneração do carvão ativado simultaneamente, além de reduzir os custos de operação (INCE, APIKYAN, 2000).

Alguns estudos mostram ainda que os POA acoplados com CAG (carvão ativado granular) ou $C A B$ (carvão ativado granulado com biofilme) podem melhorar a eficiência de remoção da matéria orgânica (SOUZA, 2010). Alvárez et al. (2009) compararam a ozonização catalítica (processo que implica simultaneamente na ozonização e na adsorção em carvão ativado) com a regeneração do carvão por ozônio e obtiveram uma relação ótima ao utilizar $0,4 \mathrm{~g}$ de $\mathrm{O}_{3}$ por grama de carvão ativado, com resultados apresentando cerca de $90 \%$ de eficiência de regeneração.

Horng e Tseng (2008) estudaram a regeneração de carvão ativado granular saturado com acetona e álcool isopropílico utilizando a oxidação pela combinação de peróxido de hidrogênio com radiação UV. Os autores trabalharam com até oito ciclos regenerativos e observaram que as taxas de dessorção da acetona a partir do CAG no processo de regeneração são maiores em pH ácido; além disso, o aumento na dosagem de oxidante influenciou positivamente a reação (a reação ocorrreu mais rapidamente) e observou-se que a utilização de radiação UV de modo intermitente requer menos oxidante para alcançar a regeneração do carvão dentro de um certo intervalo de tempo. Por fim, o método possui como vantagem o fato de permitir o controle da variável $\mathrm{pH}$. 
Álvarez et al. (2009) estudaram a regeneração com ozônio, para uma variedade de carvões ativados preparados em laboratório saturados com fenol. As doses de ozônio e a natureza do CAG mostraram ter grande influência no desempenho da regeneração, de modo que para cada carvão individual existe uma dose ótima de ozônio pela qual o fenol é eliminado juntamente com os coprodutos da sua oxidação, sem alterar a superfície química do carvão. No entanto, se uma grande quantidade de ozônio for aplicada, serão formados grupos ácidos na sua superfície, diminuindo a capacidade de adsorção do fenol. Os tempos de reação para estes experimentos foram de 20 a 90 minutos, para produzir diferentes graus de regeneração. Assim, usado como agente regenerante, o ozônio se mostrou efetivo para remover tanto o fenol fisicamente adsorvido, quanto o quimicamente adsorvido na superfície do carvão ativado.

Liang et al., (2009) avaliaram o uso do carvão para remediar a contaminação por tricloroetileno através da adsorção e regeneração oxidativa por perssulfato e por perssulfato/ $/ \mathrm{FS}_{2}$. Esta última combinação mostrou poder oxidante muito mais agressivo em comparação ao perssulfato sozinho, mineralizando o tricloroetileno para formar íons cloreto, além de degradar o composto. Ainda, este método mostrou produzir menos poluentes secundários do que métodos térmicos de regeneração. Os dois métodos causaram a perda de capacidade de adsorção do carvão ativado regenerado. Huling et al. (2011) estudaram a regeneração do carvão ativado contaminado com metil terc-butil éter utilizando o perssulfato ativado termicamente, ou com peróxido de hidrogênio, empregando um CAG comercial. Variaram-se as taxas de aplicação do perssulfato, de modo que alguns experimentos envolviam uma alta frequência de aplicação, com pequeno volume, enquanto outros envolviam um grande volume de aplicação, com baixa frequência, resultando no mesmo volume e concentração de oxidante ao final dos experimentos. Os resultados obtidos mostraram que a ativação térmica do perssulfato foi efetiva e resultou em uma remoção maior do contaminante quando comparado ao sistema $\mathrm{H}_{2} \mathrm{O}_{2}$ /perssulfato. 


\section{MATERIAIS E MÉTODOS}

\subsection{Reagentes e substâncias}

Foi utilizado carvão ativado comercial granular (Cross Filter, Filtrasorb 100), fornecido pela Calgon Carbon Corporation e empregado para remover componentes que conferem sabor e odor à água, além de compostos orgânicos dissolvidos, no tratamento de água de abastecimento.

No caso do adsorbato (pesticida), utilizou-se a formulação Dinamic ${ }^{\circledR}$ grau técnico, com pureza nominal de amicarbazona de 95,4\%; para as determinações analíticas do composto ativo fez-se uso de seu padrão analítico com grau de pureza de 99,9\%, ambos fornecidos pela Arysta LifeScience do Brasil. Para a preparação da solução aquosa do herbicida, dissolveram-se as amostras em banho de ultra-som (Fisher Scientific, modelo FS110).

Nos experimentos de oxidação, utilizaram-se peroximonossulfato de potássio (PMS) da Sigma-Aldrich (47\%) e solução aquosa de $\mathrm{H}_{2} \mathrm{O}_{2} 30 \%$ P.A. (Synth).

Utilizou-se água milli-Q (Millipore) no preparo de soluções para obtenção das curvas de calibração cromatográficas. Para a fase móvel foi utilizado ácido acético 100\% (Merck) e acetonitrila grau HPLC (J.T. Baker). Para a realização dos experimentos de adsorção/regeneração, utilizou-se água purificada gerada em equipamento de osmose inversa (Elga, modelo PURELAB Prima). Para ajuste de pH das soluções foram utilizados ácido sulfúrico 98\% P.A. e hidróxido de sódio P.A. (Vetec).

\subsection{Equipamento experimental}

Nos experimentos de adsorção do carvão ativado utilizou-se um tanque cilíndrico encamisado em vidro de 1,0 L, provido de um agitador mecânico. $\mathrm{O}$ 
tanque é acoplado a uma coluna de vidro, com $200 \mathrm{~mm}$ de comprimento e $30 \mathrm{~mm}$ de diâmetro interno, contendo um leito fixo de carvão ativado. Uma bomba centrífuga é usada para circulação da solução contendo o pesticida pela coluna de carvão ativado, enquanto uma bomba peristáltica (Gilson, modelo Miniplus 3) é empregada para alimentação da solução do oxidante diretamente ao tanque, durante a regeneração do carvão ativado. $O$ desenho esquemático do equipamento é apresentado na Figura 5.

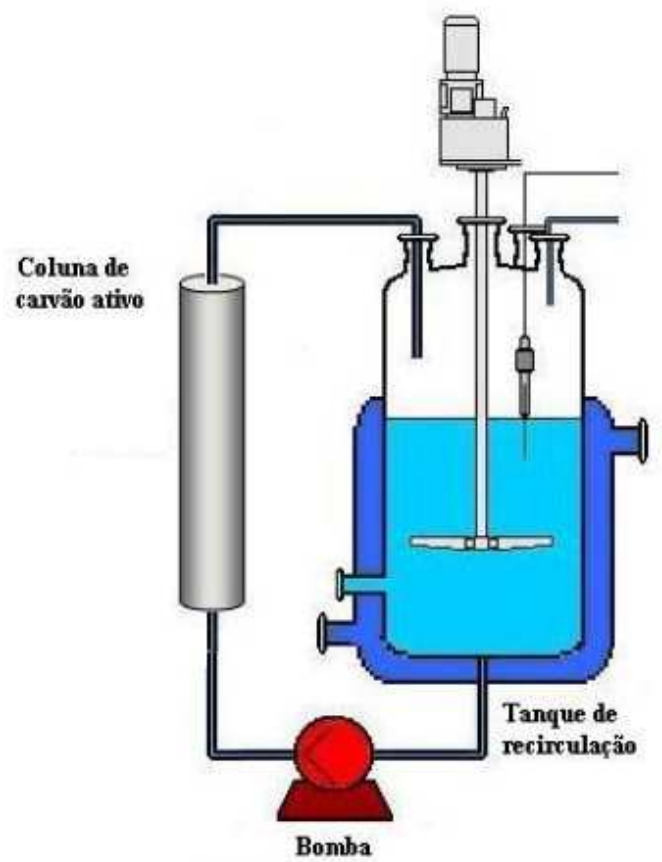

Figura 5 - Desenho esquemático do reator acoplado à coluna de leito fixo de carvão ativado.

Nos experimentos envolvendo a peroxidação assistida por radiação UV $\left(\mathrm{H}_{2} \mathrm{O}_{2} / \mathrm{UV}\right)$, foi utilizado o tanque encamisado de $1,0 \mathrm{~L}$, provido de camisa e agitador mecânico, acoplado a uma coluna de vidro com as dimensões $200 \mathrm{~mm}$ de comprimento e $30 \mathrm{~mm}$ de diâmetro interno (Figura 6), acoplados a um sistema fotoquímico de capacidade de 3,2 L, provido de uma lâmpada de vapor de mercúrio de média pressão (Philips, modelo HPLN, 125 W) inserida em um poço de quartzo encamisado com resfriamento por circulação de água. A Figura 6 mostra o desenho esquemático do equipamento descrito. 


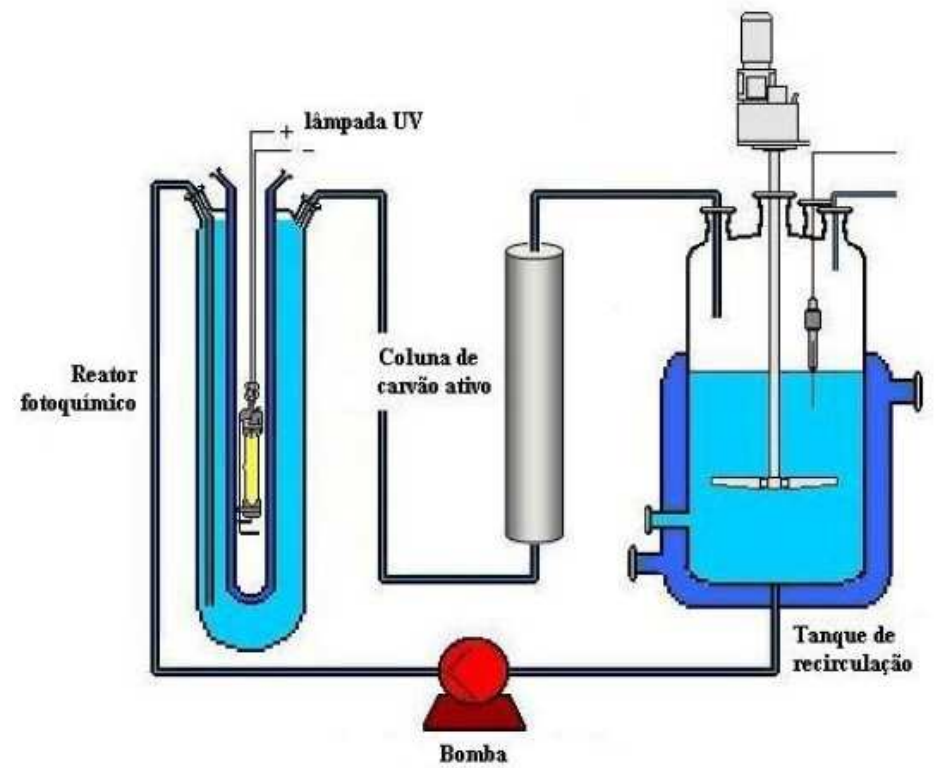

Figura 6 - Desenho esquemático do reator acoplado à coluna de leito fixo de carvão ativado para a regeneração por processo oxidativo $\mathrm{H}_{2} \mathrm{O}_{2} / \mathrm{UV}$.

\subsection{Procedimentos experimentais}

\subsubsection{Obtenção de isotermas de adsorção do pesticida no carvão ativado}

O estudo prévio da adsorção da amicarbazona nos carvões ativados empregados no trabalho, tendo em vista a obtenção das isotermas de adsorção, foi realizado a partir de um planejamento experimental segundo uma matriz Doehlert (FERREIRA et al., 2004) de 2 variáveis e o equipamento experimental (descrito no item 4.2, Figura 6) consistiu em um tanque cilíndrico encamisado acoplado a uma coluna de vidro contendo o leito fixo de carvão ativado e com circulação da solução do pesticida pela coluna. O número total de pontos experimentais do planejamento é calculado por $k^{2}+k+1$, em que $k$ é o número de variáveis independentes estudadas. Consideraram-se as seguintes variáveis:

- $U_{1}$ : Concentração de amicarbazona $\left(\mathrm{mg} \mathrm{L}^{-1}\right)$; 
- $U_{2}$ : Massa de cavão ativado (g).

Para calcular os valores reais das variáveis $U_{1}$ e $U_{2}$, utilizam-se as Equações 11 a 13, em que $X_{\mathrm{i}}$ corresponde ao valor codificado da variável $i$ (entre 0 e 1):

$$
U_{\mathrm{i}}=U_{0}+\Delta U \cdot X_{\mathrm{i}}
$$

Em que:

$$
U_{0 i}=\left(U_{i \max }+U_{\mathrm{i} \text { min }}\right) / 2
$$

é o valor de $U_{\mathrm{i}}$ no centro da região experimental e

$$
\Delta U_{\mathrm{i}}=\left(U_{\mathrm{i} \max }-U_{\mathrm{i} \text { min }}\right) / 2
$$

corresponde ao intervalo de variação de $U_{\mathrm{i}}$.

O planejamento experimental Doehlert é apresentado esquematicamente na Figura 7 e a Tabela 6 apresenta os valores máximos e mínimos, referentes ao planjemento, bem como $U_{0 i}$ e $\Delta U_{i}$, para cada variável independente estudada. Também são apresentados os valores codificados e reais. 


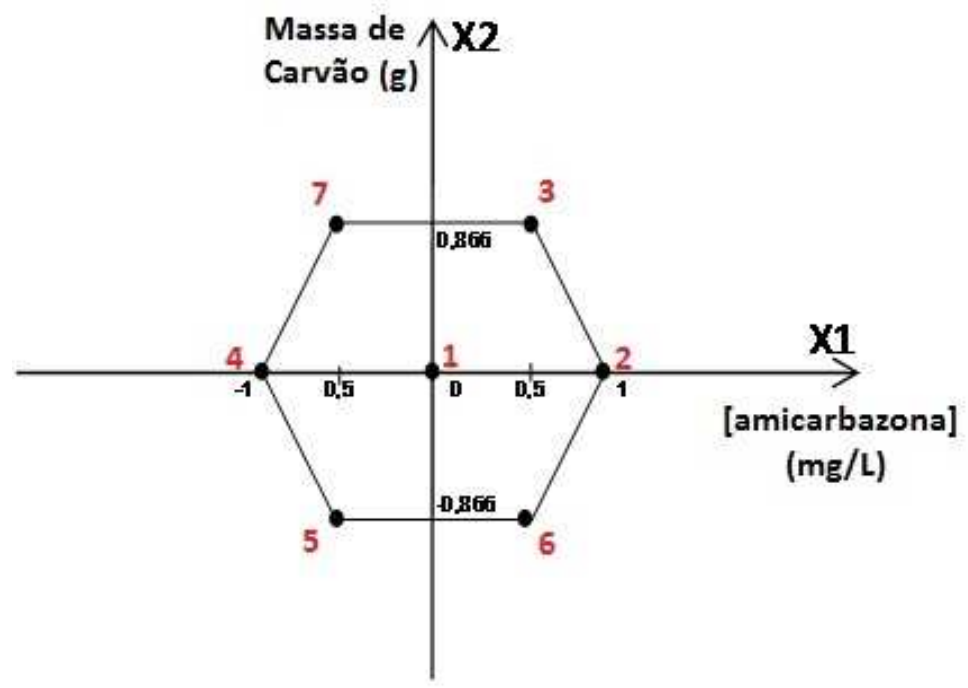

Figura 7 - Representação esquemática da distribuição dos experimentos segundo o planejamento experimental Doehlert. $X_{1}$ : valor codificado correspondente à concentração de amicarbazona e $X_{2}$ : valor codificado correspondente à massa de carvão ativado. Os números dos experimentos são indicados nos vértices e no centro do hexágono.

Tabela 6 - Domínio experimental dos valores nominais das variáveis estudadas.

\begin{tabular}{|c|c|c|c|c|}
\hline \multirow[b]{2}{*}{ Experimento } & \multicolumn{2}{|c|}{ Valores Codificados } & \multicolumn{2}{|c|}{ Valores Reais } \\
\hline & $X_{1}$ & $X_{2}$ & $\begin{array}{l}\text { Concentração de } \\
\text { amicarbazona } \\
\left(\mathrm{mg} \mathrm{L}^{-1}\right) \\
U_{1}\end{array}$ & $\begin{array}{c}\text { Massa de carvão } \\
(\mathrm{g}) \\
U_{2}\end{array}$ \\
\hline 1 & 0 & 0 & 60 & 5,5 \\
\hline 2 & 1 & 0 & 100 & 5,5 \\
\hline 3 & 0,5 & 0,866 & 80 & 9,4 \\
\hline 4 & -1 & 0 & 20 & 5,5 \\
\hline 5 & $-0,5$ & $-0,866$ & 40 & 1,6 \\
\hline 6 & 0,5 & $-0,866$ & 80 & 1,6 \\
\hline 7 & $-0,5$ & 0,866 & 40 & 9,4 \\
\hline
\end{tabular}

A concentração é uma concentração de trabalho adotada no grupo de pesquisa, baseada em valores tipicos de efluentes reais. $O$ intervalo de massa de carvão foi selecionado em função do tamanho da coluna a ser utilizada e da quantidade total de amostra disponivel. 
Definida a massa de carvão ativado a partir desses experimentos prévios, obtiveram-se isotermas de adsorção de amicarbazona em carvão ativado, em diferentes $\mathrm{pH}$ ( 3 e 7), conforme o procedimento a seguir:

1) Prepararam-se soluções aquosas de amicarbazona, com concentração variando entre 20 a $100 \mathrm{mg} \mathrm{L}^{-1}$. O volume total utilizado de cada solução foi de $115 \mathrm{~mL}$, dispostos em erlenmeyers com capacidade para $200 \mathrm{~mL}$;

2) Antes de adicionar carvão aos erlenmeyers, retirou-se um volume de $1 \mathrm{~mL}$ de cada um, para determinar a concentração inicial real das soluções por análise cromatográfica;

3) Imediatamente após a adição do carvão ativado, os frascos foram colocados em uma incubadora termostatizada com agitação orbital (Tecnal, modelo TE-421), a $25^{\circ} \mathrm{C}$ e $130 \mathrm{rpm}$, por um período de 2 horas;

4) Acompanhou-se a adsorção retirando-se alíquotas de $1 \mathrm{~mL}$, em intervalos de tempo pré-determinados;

5) As amostras foram filtradas em membrana Millipore de $22 \mu \mathrm{m}$ e sua concentração foi medida por cromatografia líquida.

A quantidade de amicarbazona adsorvida por massa de carvão no equilíbrio foi calculada utilizando a Equação 14:

$$
q_{\text {eq }}=\left(C_{0}-C_{\text {eq }}\right) \cdot V / m
$$

em que $C_{0}$ é a concentração inicial de amicarbazona, $C_{\text {eq }}$ a concentração no equilíbrio, medida ao final de duas horas de adsorção, $V$ é o volume da solução $e$ $m$, a massa de carvão. Um gráfico de $q_{\text {eq }}$ em função de $C_{\text {eq }}$ fornece a isoterma de adsorção.

\subsubsection{Regeneração pelo processo oxidativo $\mathrm{H}_{2} \mathrm{O}_{2} / \mathrm{UV}$}

O processo combinado (duas etapas) consiste primeiro em passar a solução contendo o herbicida em carvão ativado por um período de $2 \mathrm{~h}$ (etapa de 
adsorção), após o que segue a etapa de tratamento do mesmo por $\mathrm{H}_{2} \mathrm{O}_{2} / \mathrm{UV}$, por $4 \mathrm{~h}$. Uma bomba centrífuga permitiu a circulação da solução de amicarbazona pela coluna de leito fixo de carvão ativado (Figura 6). Tem-se assim um ciclo adsorção-oxidação e, ao final deste, obtém-se o carvão ativado tratado. Esse procedimento foi realizado por três vezes consecutivas, com a finalidade de avaliar o comportamento do carvão após os ciclos. Os experimentos foram realizados de acordos com as etapas:

- Limpeza do reator com água destilada;

- Utilizou-se uma balança analítica (Mettler Toledo, modelo XS205 DualRange) para pesar a massa do pesticida, a qual foi dissolvida em balão volumétrico, utilizando-se o equipamento Ultrasonic Cleaner Fisher Scientific FS110;

- A amostra inicial foi retirada do próprio balão, antes da solução ser carregada ao reator;

- Carregou-se a solução aquosa de amicarbazona (3,5 L) ao reator e, após preencher o sistema, a bomba foi acionada, a vazão ajustada e o banho termostático ligado com objetivo de manter o líquido a temperatura constante de $25^{\circ} \mathrm{C}$;

- Deu-se início à reação, com pH, temperatura e vazão de recirculação mantidos constantes. A solução contendo $\mathrm{H}_{2} \mathrm{O}_{2}$ (30\%) foi adicionada com a ajuda de uma bomba peristáltica (AWM - 5900 - AX-D, Steck), à vazão de $4 \mathrm{~mL} \mathrm{~h}^{-1}$. A solução foi monitorada através de um termômetro digital e de um pH-metro (cf. seção 4.4.4);

- $\mathrm{O} \mathrm{pH}$ foi mantido constante (ácido/neutro), quando necessário, usando solução aquosa de $\mathrm{H}_{2} \mathrm{SO}_{4} 10 \%$;

- Coletaram-se amostras em tempos pré-determinados;

- Caracterizaram-se as amostras segundo as técnicas analíticas descritas posteriormente;

- Descarga e limpeza do reator.

Para identificar a presença de peróxido de hidrogênio residual na solução, mesmo que em pequenas quantidades, utilizou-se a solução de metavanadato de 
amônio $\left(\mathrm{NH}_{4} \mathrm{VO}_{3}\right)$, que é amarela e quando entra em contato com o peróxido de hidrogênio, reage formando um composto de cor avermelhada o qual possui pico de absorção a $450 \mathrm{~nm}$. A solução foi preparadada seguinte forma (NOGUEIRA et al., 2005) :

1) Aquecer $1,75 \mathrm{~g}$ de vanadato de amônio em um béquer, utilizando uma chapa de aquecimento a $50^{\circ} \mathrm{C}$;

2) Adicionar, lentamente, $16,1 \mathrm{~mL}$ de solução de ácido sulfúrico $9 \mathrm{~mol} \mathrm{~L}^{-1}$;

3) Prosseguir o aquecimento, com agitação constante, até que todo o vanadato solubilizar;

4) Esperar a solução esfriar. Neste momento a cor da solução deverá ser vermelho escuro;

5) Diluir toda a amostra em balão volumétrico de $250 \mathrm{~mL}$, com água destilada.

\subsubsection{Regeneração por peroximonossulfato de potássio (PMS)}

Esta etapa do trabalho de regeneração por peroximonossulfato de potássio diferencia-se do apresentado no intem 4.3.2, uma vez que esta foi realizada em erlenmeyer com $200 \mathrm{~mL}$ de capacidade (e não em reator) e com a massa de $1 \mathrm{~g}$ de carvão ativado (o volume efetivo utilizado de solução foi de 100 $\mathrm{mL}$, para garantir espaço para uma agitação efetiva do sistema). Além disso, os processos de adsorção e regeneração foram feitos em uma incubadora termostatizada com agitação orbital (Tecnal, modelo TE-421), a $2^{\circ} \mathrm{C}$ e $160 \mathrm{rpm}$, para garantir de homogeneização total das amostras.

Antes de adicionar a solução contendo amicarbazona ao carvão ativado (no erlenmeyer), retirou-se uma amostra de $1 \mathrm{~mL}$ para determinar a real concentração inicial das soluções, por análise cromatográfica. Após o início do processo adsorção/ regeneração, acompanhou-se 0 desenvolvimento do experimento retirando-se alíquotas de $1 \mathrm{~mL}$, em intervalos de tempo pré- 
determinados, e as amostras foram filtradas em membrana Millipore de $22 \mathrm{~nm}$ com a concentração medida por cromatografia líquida.

O processo combinado (duas etapas) consiste primeiro em passar a solução contendo o herbicida pela etapa de adsorção em carvão ativado por um período de $2 \mathrm{~h}$, em erlenmeyer. Feito isso, filtrou-se o carvão para separá-lo da solução remanescente de amizarbazona, após o que segue a etapa de tratamento do mesmo por PMS, por intervalos de tempo variáveis. Tem-se assim um ciclo adsorção-oxidação e, ao final deste, obtêm-se o carvão ativado após tratamento. Esse procedimento foi realizado por três vezes consecutivas, com a finalidade de avaliar o comportamento do carvão após os ciclos.

\subsection{Técnicas analíticas e de medição}

\subsubsection{Cromatografia líquida de alta eficiência (HPLC) com detector UV}

As análises das soluções de amicarbazona foram realizadas em HPLC (Shimadzu, modelo LCMS - 2010A), equipado com detector UV-visível, conforme trabalho previamente feito por Cavenaghi et al. (2007), fazendo-se injeções do padrão analítico, com concentrações de até $150 \mathrm{mg} \mathrm{L}^{-1}$, em fase móvel composta por água/acetonitrila em diferentes proporções. Para tanto, variou-se a quantidade de acetonitrila de $15 \%$ a $40 \%$, segundo o gradiente apresentado na Figura 8 . Os solventes utilizados foram acidificados com $0,2 \%$ de ácido acético glacial. A temperatura utilizada foi de $20-22^{\circ} \mathrm{C}$ (em sala com temperatura ambiente controlada), à vazão de $1,0 \mathrm{~mL} \mathrm{~min}^{-1} \mathrm{e}$ pressão de aproximadamente $80 \mathrm{kgf} \mathrm{cm}^{-2}$. Utilizou-se uma coluna Luna C8, com $150 \times 4,6 \mathrm{~mm}$ e diâmetro de $5 \mu \mathrm{m}$, equipada com pré-coluna apropriada (Phenomenex, AJO - 4290) e o detector UV (Shimadzu, modelo SPD-10AVvp) foi ajustado em $230 \mathrm{~nm}$. 




Figura 8 - Gradiente empregado na análise de amicarbazona por HPLC.

\subsubsection{Carbono orgânico total (TOC)}

As análises de carbono orgânico total foram executadas em analisador TOC Shimadzu, modelo 5000A, com injeção automática e queima da amostra em forno de alta temperatura $\left(680^{\circ} \mathrm{C}\right)$, com catalisador de platina, sob atmosfera enriquecida em $\mathrm{O}_{2}$. A matéria orgânica oxidada a gás carbônico é determinada por um sensor de infravermelho não dispersível (NDIR). O equipamento quantifica as frações de carbono total (TC) e carbono inorgânico (IC), contidas nas amostras e a diferença entre essas medidas fornece como resultado a concentração de carbono presente no líquido na forma de compostos orgânicos solúveis.

\subsubsection{Espectrofotometria UV-visível}

Para verificar a existência de excesso de peróxido de hidrogênio na reação de regeneração do carvão ativado, utilizou-se a espectrofotometria UV- 
visível aliada ao método do metavanadato de amônio (ver item 4.3.2). Todas as medidas de absorbância em modos simples e de varredura foram realizadas em espectrofotômetro marca Varian, modelo Cary 50, na faixa de comprimentos de onda 190-820 nm e resolução de $5 \mathrm{~nm}$. Foram utilizadas cubetas de quartzo com caminho óptico de $1 \mathrm{~cm}$ nas determinações espectrofotométricas.

\subsection{4. $\mathrm{pH}$}

Em todos os experimentos, o $\mathrm{pH}$ foi medido pelo método potenciométrico utilizando um equipamento convencional (Hanna Instruments, modelo HI 221), previamente calibrado com soluções tampão de pH 4,0 e 7,0.

\subsection{Caracterização do carvão ativado}

\subsection{1. Área superficial específica BET}

As isotermas de adsorção de nitrogênio do carvão ativado foram obtidas a $-196^{\circ} \mathrm{C}$, temperatura do nitrogênio líquido, num equipamento Quantacrome 100E, cuja análise foi realizada no Grupo de Pesquisa em Química Verde e Ambiental (GPQVA), do Instituto de Química da USP. A área superficial específica dos materiais foi determinada empregando-se o método de Brunauer, Emmett e Teller (1938), para pressões relativas $\left(P / P_{0}\right)$ entre 0,1 e 0,9. 


\subsubsection{Microscopia eletrônica de varredura (MEV)}

O princípio de funcionamento do MEV (Jeol, modelo JSM7401F) consiste na emissão de um feixe de elétrons de alta energia que incide na superfície da amostra. Dessa interação parte do feixe é refletido e coletado por um detector que converte este sinal em imagem de ES (elétrons secundários). A análise foi realizada na Central Analítica do Instituto de Química da USP e foi necessário o recobrimento da amostra por uma película condutora de ouro, fazendo assim a chamada metalização, que favorece muito as imagens do MEV.

\subsubsection{Teor de umidade}

$\mathrm{O}$ teor de umidade foi determinado pesando-se $1 \mathrm{~g}$ de material em um cadinho de porcelana previamente tarado, transferido na sequência para uma estufa e aquecido até $120^{\circ} \mathrm{C}$, à qual foi mantido. Foram feitas pesagens até massa constante (aproximadamente $5 \mathrm{~h}$ ). $\mathrm{O}$ teor de umidade corresponde à diferença entre a massa total e a massa perdida.

\subsubsection{Teor de cinzas}

O conjunto cadinho + carvão descrito no item 4.5.3 (após remoção de umidade), foi colocado em uma mufla e aquecido até $550^{\circ} \mathrm{C}$, à qual foi mantido até calcinação completa do carvão (6h). $\mathrm{O}$ teor de cinzas foi calculado a partir da massa final da amostra e após remoção prévia da umidade. 


\subsubsection{Teor de voláteis}

O teor de voláteis foi determinado pesando-se cerca de $6 \mathrm{mg}$ de material em um cadinho de platina previamente tarado, transferido-o na sequência para o equipamento de análise termogravimétrica (DTG-60H, Shimadzu), até aquecimento a $9500^{\circ} \mathrm{C}$, sob atmosfera de $\mathrm{N}_{2}$. O teor de voláteis corresponde à diferença entre a massa total e a massa final, descontada a umidade.

\subsubsection{Análise granulométrica}

A medida consiste em passar as partículas do carvão ativado por uma série de peneiras (série $A B N T$ ), cujas aberturas são sucessivamente menores. Essa determinação da granulometria média dos carvões utilizados no trabalho foi feita a partir de $50 \mathrm{~g}$ de amostra, utilizando-se 4 peneiras de 8, 10, 18 e 20 mesh (aberturas das malhas de 2,36 mm, 1,7 mm, $1 \mathrm{~mm}$ e $850 \mu \mathrm{m}$, respectivamente) mais 1 recipiente para retenção das partículas não retidas pelas mesmas. $O$ conjunto de peneiras e recipiente foi agitado em um shaker por 1 minuto (um tempo maior não é adequado já que testes prévios mostraram a ocorrência de quebra dos grânulos de carvão em partículas menores). 


\section{RESULTADOS E DISCUSSÃO}

\subsection{Caracterização do carvão ativado empregado no trabalho}

Nas subseções a seguir é apresentada a caracterização do carvão ativado utilizado como adsorvente neste trabalho a partir das análises de BrunauerEmmet-Teller (B.E.T.), de microscopia eletrônica de varredura (MEV), teor de cinzas, teor de materiais voláteis e análise granulométrica.

\subsubsection{Análise BET}

A análise da isoterma de adsorção/dessorção de $N_{2}$ (Figura 9) pelo método BET cuja análise foi realizada no Grupo de Pesquisa em Química Verde e Ambiental (GPQVA), do Instituto de Química da USP, indicou elevada adsorção a baixas pressões de $\mathrm{N}_{2}$, evidenciando a presença de microporos, como esperado para carvões ativados. Pode-se observar que o carvão estudado apresenta isoterma com comportamento característico para adsorção em monocamada. A área superficial encontrada para o carvão Filtrasorb 100, conforme o método BET, foi de aproximadamente $700 \mathrm{~m}^{2} \mathrm{~g}^{-1}$, compatível com o encontrado na maioria dos carvões ativados comerciais nacionais (MUCCIACITO, 2006). 


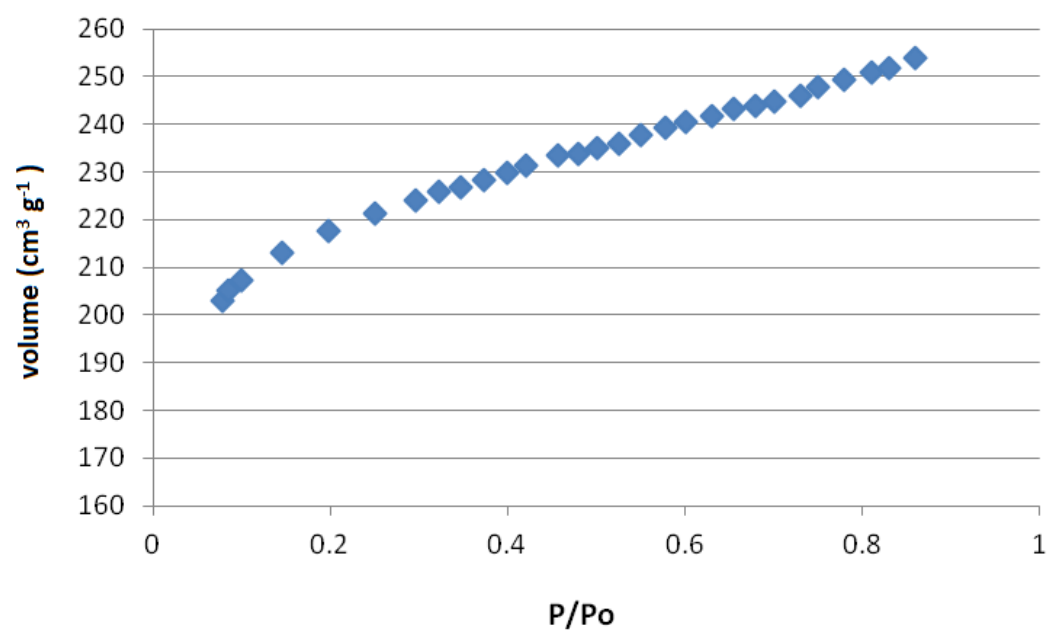

Figura 9 - Isoterma de adsorção do carvão ativado Filtrasorb 100.

\subsubsection{Análise MEV (Microscopia Eletrônica de Varredura)}

A análise morfológica do carvão ativado, realizada por microscopia eletrônica de varredura (MEV), na Central Analítica do Instituto de Química da USP, como esperado, permitiu identificar superfície porosa irregular (crateras disformes), ou seja, é possível perceber a existência de uma rede porosa que participa da retenção da substância a ser adsorvida. As Figuras 10, 11 e 12 apresentam algumas micrografias obtidas, com aumentos de 250, 1000 e 5000 vezes, respectivamente.

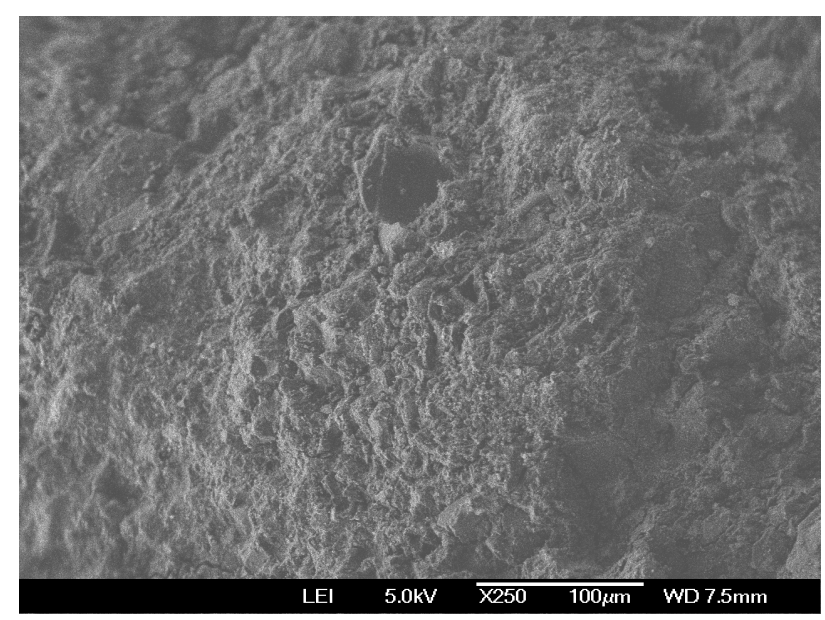

Figura 10 - Micrografia por MEV da superfície de carvão ativado, com aumento de 250 vezes. 


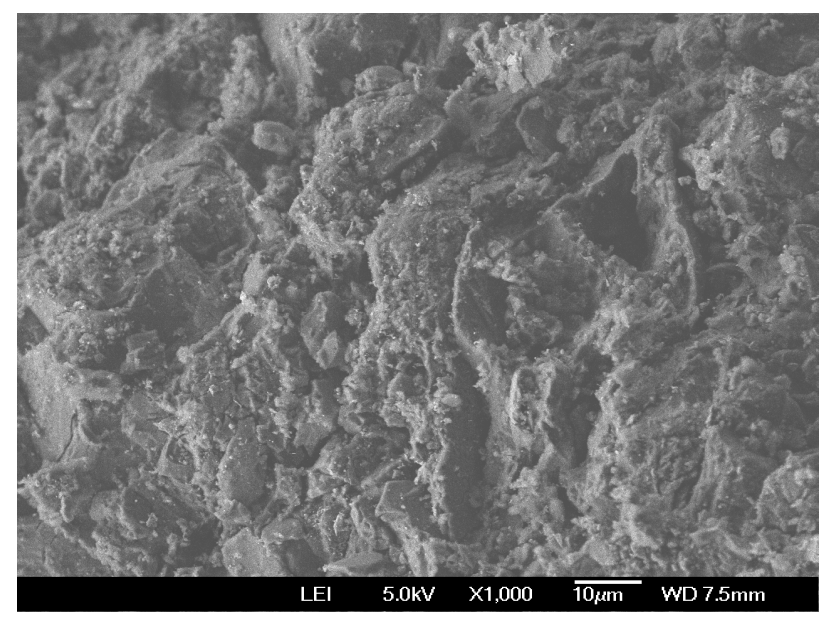

Figura 11 - Micrografia por MEV da superfície de carvão ativado, com aumento de 1000 vezes.

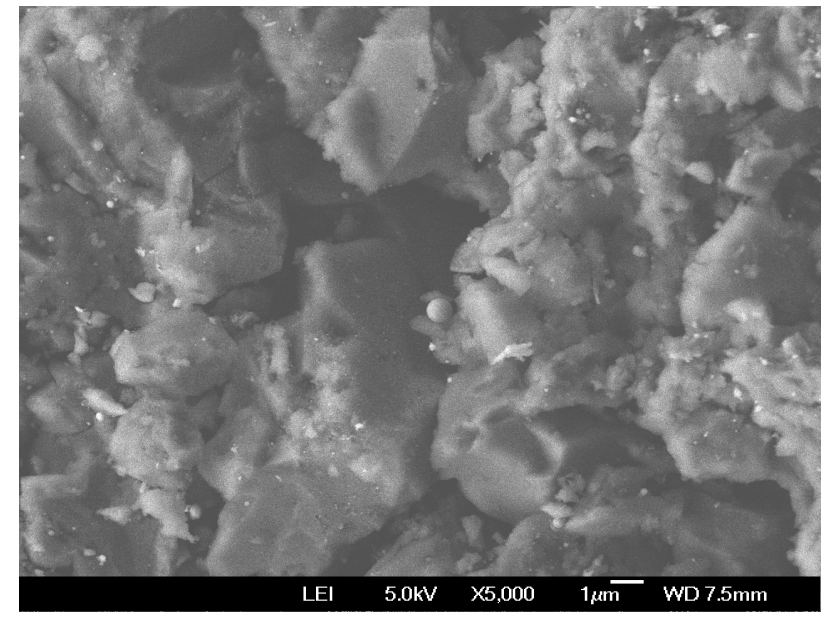

Figura 12 - Micrografia por MEV da superfície de carvão ativado, com aumento de 5000 vezes.

Observa-se uma estrutura altamente porosa, bem definida, irregular, com a presença de micro, meso e macroporos.

\subsubsection{Teor de umidade}

Os resultados das análises encontram-se na Tabela 7. O total de água presente em amostras de carvão ativado é resultante da combinação entre 
umidade superficial e a inerente ao produto. A incorporação de água pode ocorrer durante as etapas de fabricação, transporte e /ou armazenamento do carvão.

Os resultados mostram que o carvão ativado Filtrasorb 100 empregado no trabalho possui teor médio de umidade de 1,5\%. Este valor é considerado baixo, não interferindo apreciavelmente na massa de carvão.

Tabela 7 - Resultados obtidos na análise do teor de umidade.

\begin{tabular}{cccc}
\hline Análise & $\begin{array}{c}\text { Teor de } \\
\text { umidade (\%) }\end{array}$ & Média & $\begin{array}{c}\text { Desvio } \\
\text { Padrão }\end{array}$ \\
\hline 1 & $1,9 \%$ & & \\
2 & $1,4 \%$ & $1,5 \%$ & $0,3 \%$ \\
3 & $1,3 \%$ & & \\
\hline
\end{tabular}

\subsubsection{Teor de cinzas}

Os resultados das análises encontram-se na Tabela 8. Segundo Jaguaribe et al. (2005), este parâmetro é um indicador da qualidade do carvão ativado e em geral o teor de cinzas de um carvão ativado comercial é de até $15 \%$.

O carvão ativado analisado possui teor médio de cinzas de $27,2 \%$, o qual está diretamente relacionado ao método de ativação e ao fato de os compostos inorgânicos presentes no material percursor do carvão ficarem retidos após o processo de pirólise e não serem lixiviados após lavagens posteriores do mesmo (RAMOS et al., 2009). Esse elevado teor de cinzas pode influenciar de forma negativa na capacidade de adsorção dos materiais, pois os contaminantes devem ser adsorvidos nas superficies orgânicas e não nas superfícies inorgânicas, além do fato de que, dependendo do solvente utilizado, parte das cinzas pode ser extraída, contaminando e mudando o pH da solução (SMISEK, 1967). 
Tabela 8 - Resultados obtidos na análise do teor de cinzas.

\begin{tabular}{cccc}
\hline Análise & $\begin{array}{c}\text { Teor de cinzas } \\
(\%)\end{array}$ & Média & $\begin{array}{c}\text { Desvio } \\
\text { Padrão }\end{array}$ \\
\hline 1 & $31 \%$ & & \\
2 & $23 \%$ & $27 \%$ & $4 \%$ \\
3 & $28 \%$ & & \\
\hline
\end{tabular}

\subsubsection{Teor de materiais voláteis}

Para esta análise, pesaram-se $5,940 \mathrm{mg}$ de carvão ativado, transferidos para um cadinho de platina previamente tarado. A amostra de carvão ativado foi pirolisada a $9500^{\circ} \mathrm{C}$, em atmosfera inerte e, após a a nálise, houve perda de massa de $0,691 \mathrm{mg}$, ou seja, de 11,6\%, descontada a perda de umidade. Esse valor foi calculado pela diferença entre a massa inicial do carvão seco e sua massa final. Assim, após sua retirada tem-se a massa de carbono fixo.

\subsubsection{Análise granulométrica}

A análise granulométrica do carvão ativado comercial Filtrasorb 100 resultou na distribuição apresentada na Figura 13, que apresenta a fração de sólidos retidos em cada peneira (em relação à massa total, $50 \mathrm{~g}$ ) em função do tamanho da malha das peneiras. 


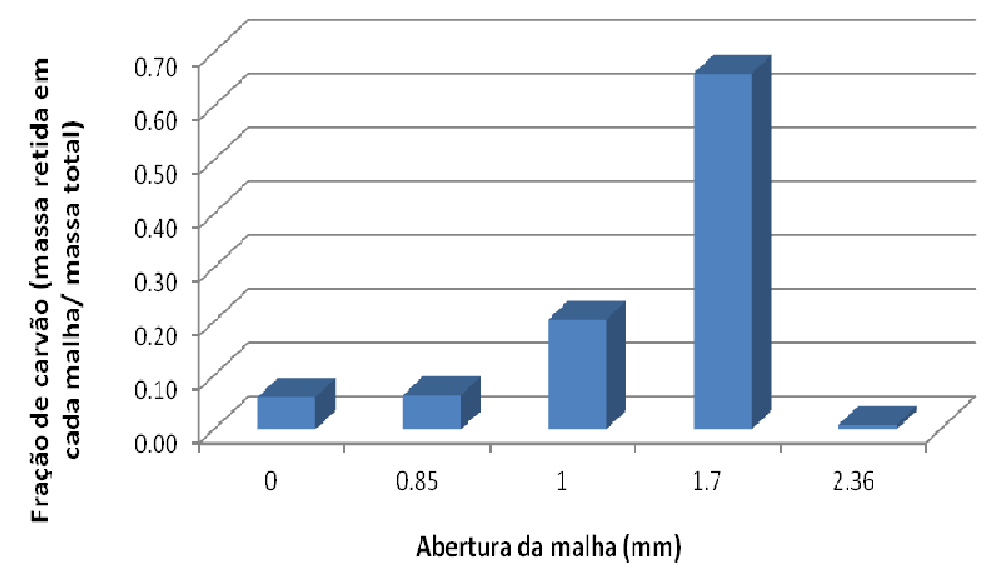

Figura 13 - Distribuição granulométrica de uma amostra de carvão ativado em função da abertura das peneiras $(\mathrm{mm})$.

Observa-se a partir desse resultado que a faixa onde se concentra a maior quantidade de material foi $1<x_{i}<1,7 \mathrm{~mm}$, sendo esta fração a utilizada nos experimentos, com a finalidade de padronização dos mesmos.

\subsection{Análise do efeito da vazão sobre a adsorção}

Desejou-se analisar o efeito da vazão sobre o processo de adsorção da amicarbazona no leito de carvão ativado disposto na coluna (cf. seção 4.2, Figura 6). Para tanto, três ciclos de adsorção consecutivos foram feitos, utilizando-se as vazões de $10 \mathrm{~L} \mathrm{~h}^{-1}$ (vazão mínima da bomba centrífuga) e $50 \mathrm{~L} \mathrm{~h}^{-1}$ (vazão máxima da bomba) e a concentração de amicarbazona em solução em função do tempo foi determinada (Figuras 14 a 17). Nessas figuras, o ciclo 1 refere-se ao primeiro ciclo de adsorção, enquanto o ciclo 2 é posterior ao 1, ou seja, o carvão já estaria parcialmente preenchido com o pesticida, o que prejudicaria a adsorção. Por fim o ciclo 3 é posterior aos outros 2 . 


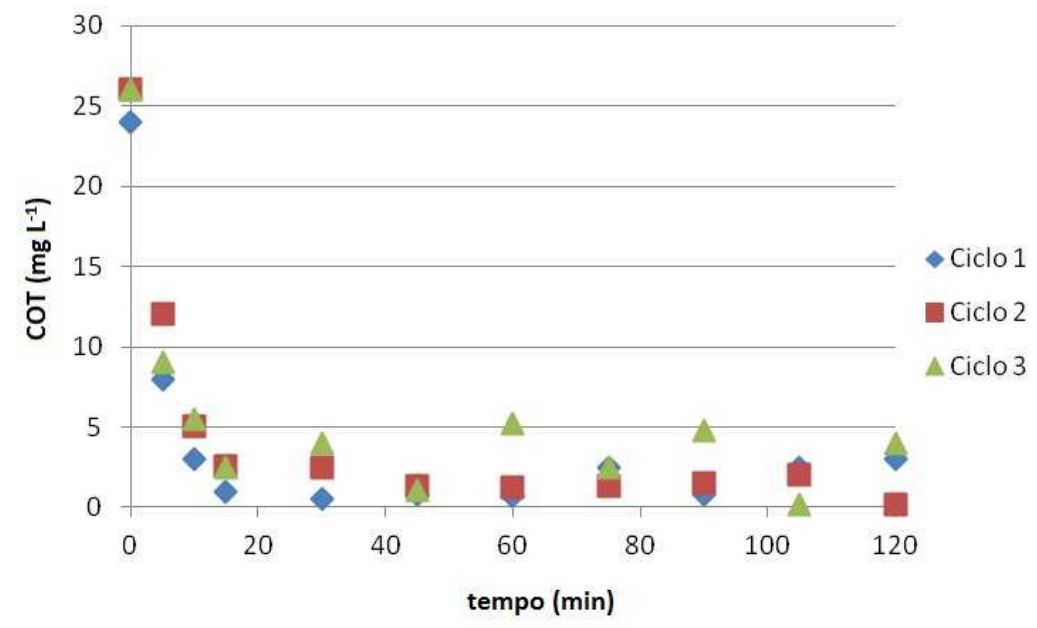

Figura 14 - Análise realizada para estudo do efeito do aumento da vazão no processo de adsorção, com resultados de COT, para uma vazão de $50 \mathrm{~L} \mathrm{~h}^{-1}$ e com concentração inicial de amicarbazona de $50 \mathrm{mg} \mathrm{L}^{-1}$.

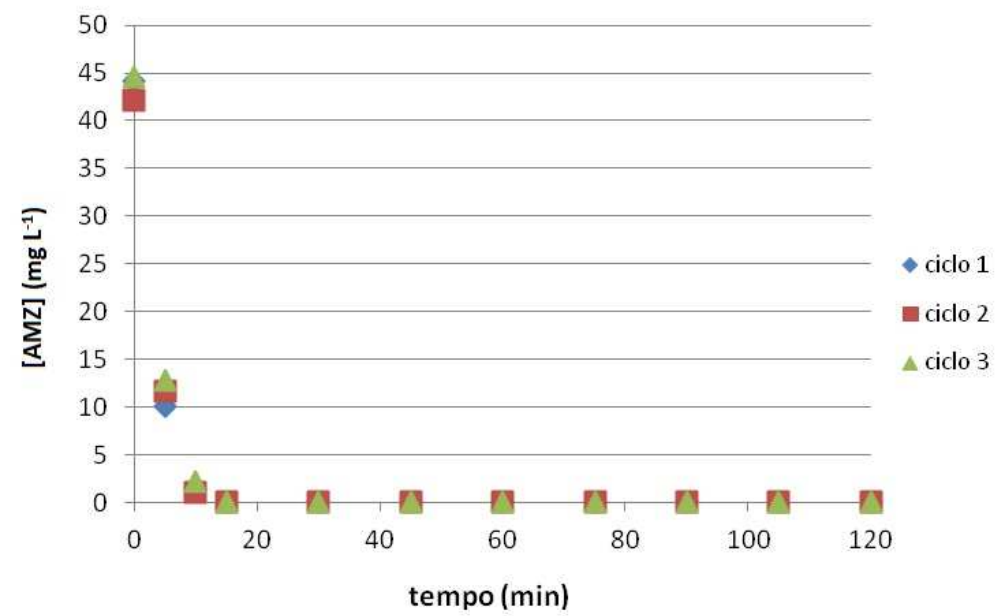

Figura 15 - Análise realizada para estudo do efeito do aumento da vazão no processo de adsorção, com resultados de [AMZ] obtidos por HPLC, para uma vazão de $50 \mathrm{~L} \mathrm{~h}^{-1}$ e com concentração inicial de amicarbazona de $50 \mathrm{mg} \mathrm{L}^{-1}$. 


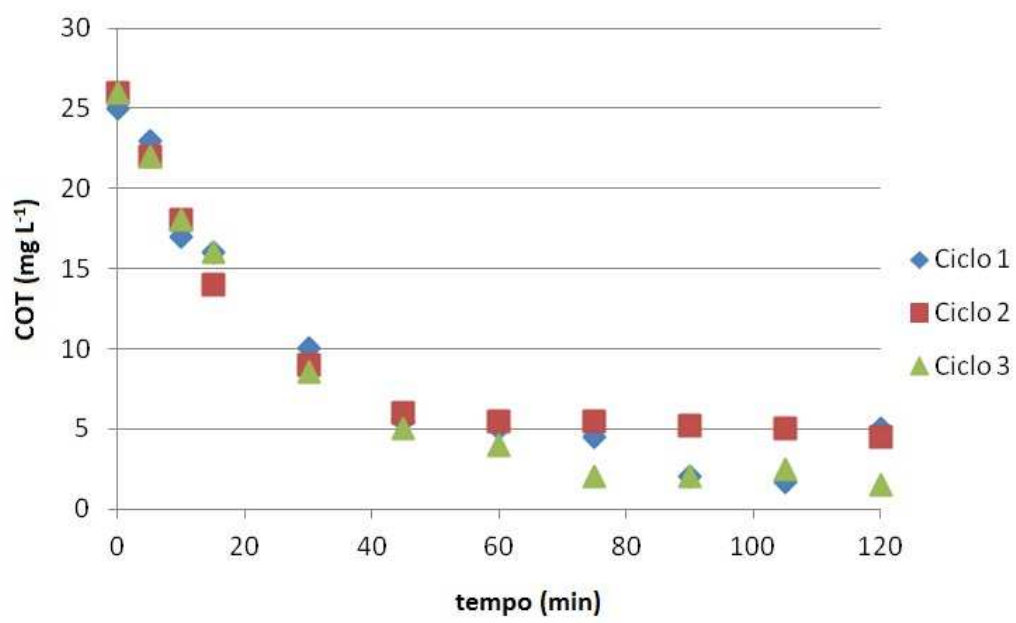

Figura 16 - Análise realizada para estudo do efeito do aumento da vazão no processo de adsorção, com resultados de COT, para uma vazão de $10 \mathrm{~L} \mathrm{~h}^{-1}$ e com concentração inicial de amicarbazona de $50 \mathrm{mg} \mathrm{L}^{-1}$.

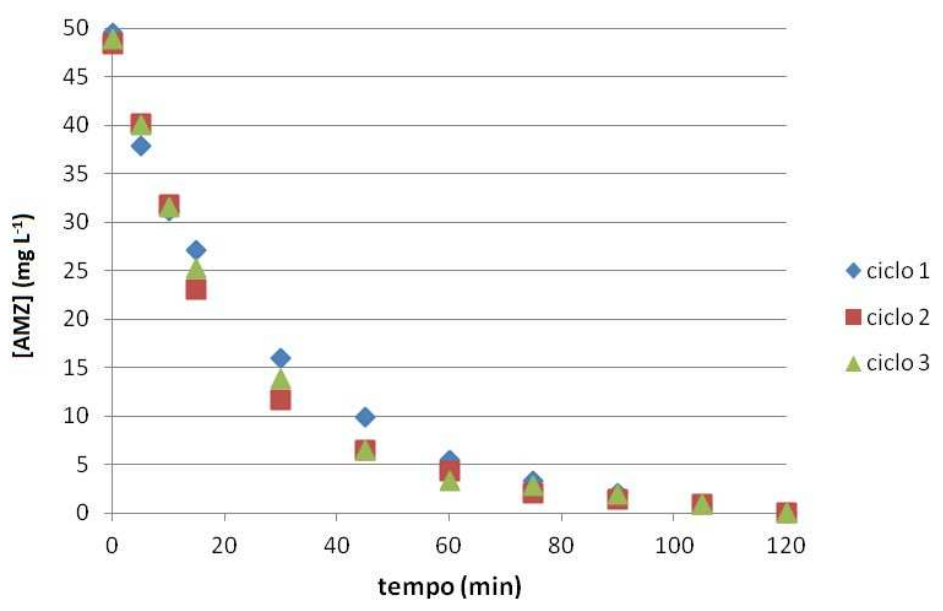

Figura 17 - Análise realizada para estudo do efeito do aumento da vazão no processo de adsorção, com resultados de [AMZ] obtidos por HPLC para uma vazão de $10 \mathrm{~L} \mathrm{~h}^{-1}$ e com concentração inicial de amicarbazona de $50 \mathrm{mg} \mathrm{L}^{-1}$.

Por meio dos diferentes comportamentos das curvas apresentadas, verifica-se que há influência da vazão no processo de adsorção, já que o aumento da mesma promove a saturação do leito de maneira mais rápida, uma vez que o aumento da vazão altera a difusão do fluido no leito, pois é um caso em que o processo de adsorção é controlado pela resistência à transferência de massa no interior da partícula. Esta análise, contudo, não leva em consideração o fato de que ao considerar certo período de tempo a vazões diferentes, a quantidade de solução que terá circulado pelo carvão também é diferente, já que os tempos de 
residência da solução na coluna de CA são diferentes. Para corrigir esse problema, deve-se considerar o volume total de solução circulada no reator, independente do tempo que isso levará em cada situação. Assim, os experimentos realizados com baixas vazões volumétricas resultaram em elevados tempos de residência, permitindo que ocorresse a adsorção, consequentemente aumentando a quantidade de amicarbazona adsorvida na fase estacionária (WATSON, 1999; VIJAYARAGHAVAN et al., 2005). Com essas possibilidades, optou-se por utilizar a vazão de $50 \mathrm{~L} \mathrm{~h}^{-1}$ para a realização dos experimentos em reator.

Como alguns pontos das análises por COT ficaram um pouco diferentes do esperado, optou-se por fazer um processo de dessorção do carvão ativado para verificar se o mesmo liberava a amicarbazona novamente em solução. Para tal, esvaziou-se o sistema após um ciclo de adsorção e completou-se novamente seu volume somente com água destilada. Deu-se início ao mesmo processo utilizado para fazer a adsorção porém fazendo-se a dessorção, com amostras sendo retiradas em tempos pré-determinados por um período total de 2 horas (dessorção). O resultado obtido encontra-se na Figura 18.

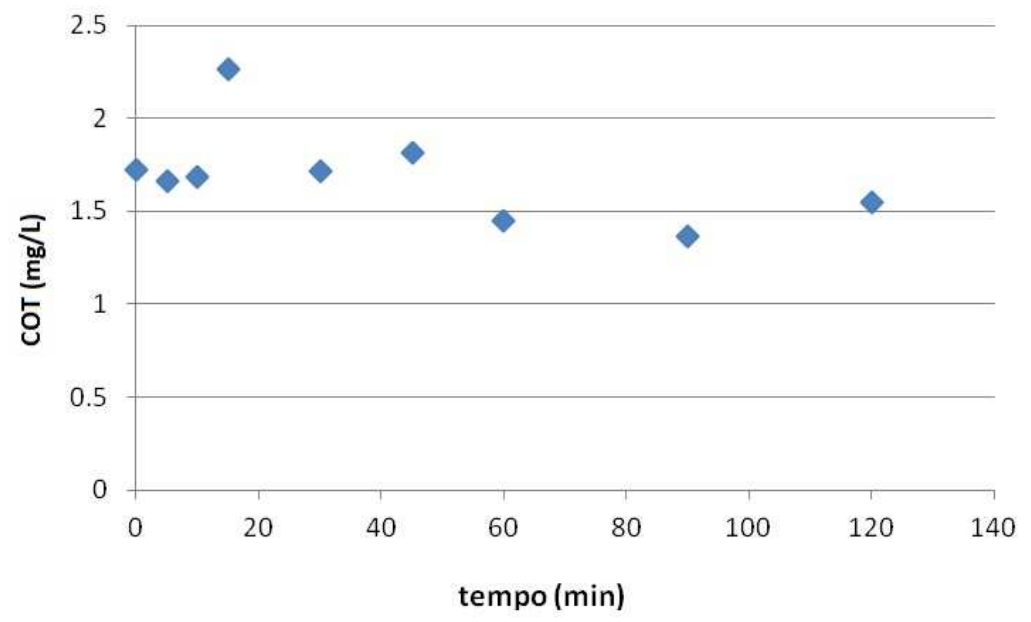

Figura 18 - Ensaio de dessorção da amicarbazona (AMZ) a partir do carvão ativado contaminado com o herbicida.

Para verificar se os valores obtidos para a análise de COT da dessorção correspondiam a amicarbazona especificamente ou ao erro da análise, realizouse a análise de COT da água destilada (Figura 19). As mesmas foram feitas ao longo do tempo, para simular condições experimentais semelhantes as dos 
experimentos com carvão propriamente ditas e, consequentemente, analisar a flutuação dos resultados do equipamento com o tempo.

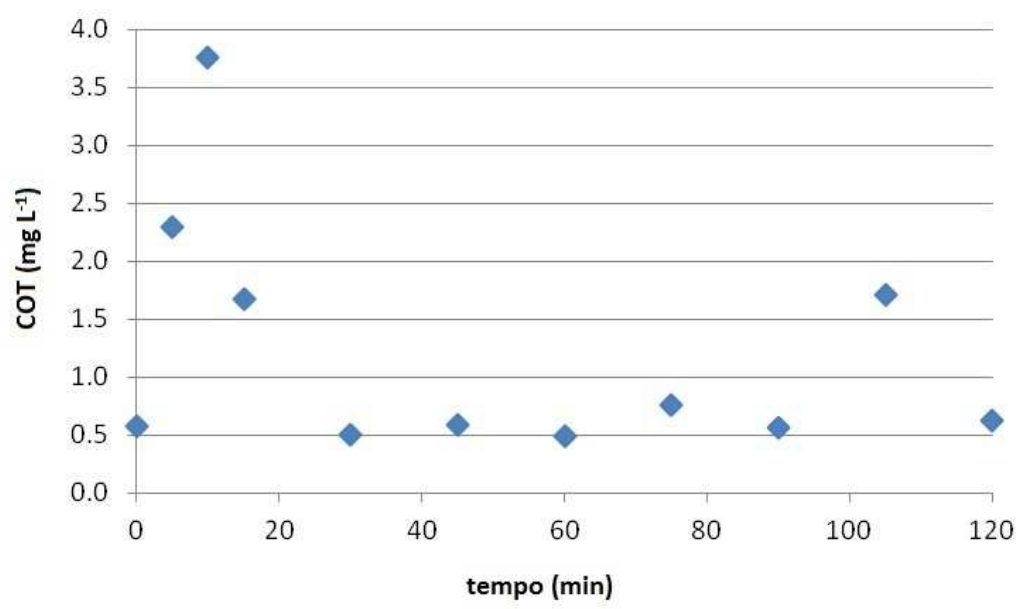

Figura 19 - Medidas de COT da água.

A Figura 19 permite concluir que uma variação de 4 unidades para a análise de COT pode ser considerada como erro associado ao equipamento e não necessariamente um aumento/diminuição na concentração de amicarbazona em solução. Ou seja, mesmo o pico observado no tempo de 15 minutos da Figura 19 está dentro do erro associdado. Ainda, não se pode afirmar com certeza que os valores obtidos na Figura 18 sejam efetivamente da dessorção da amicarbazona do carvão ativado, já que se encontram dentro da flutuação da análise de COT.

\subsection{Estudo da adsorção da amicarbazona no carvão ativado}

Com o projeto experimental de distribuição uniforme baseado na matriz Doehlert (Tabela 6 e Figura 7, cf. seção 4.3.1), estabeleceram-se algumas relações de massa de carvão/concentração de poluente para estudo prévio da adsorção da amicarbazona no carvão ativado comercial Filtrasorb 100, com pH 
próximo a 7, que corresponde ao valor natural da solução de amicarbazona, o que possibilitou encontrar a relação que apresentasse maior remoção porcentual do pesticida por adsorção no carvão ativado. O equipamento experimental (descrito no item 4.2, Figura 6) consistiu em um tanque cilíndrico encamisado acoplado a uma coluna de vidro contendo o leito fixo de carvão ativado e com circulação da solução do pesticida pela coluna à vazão de $50 \mathrm{~L} \mathrm{~h}^{-1}$. As curvas obtidas para os sete experimentos (médias das triplicatas) encontram-se na Figura 20. As respostas obtidas a partir dessas soluções com diferentes concentrações do contaminante são apresentadas na Tabela 9.

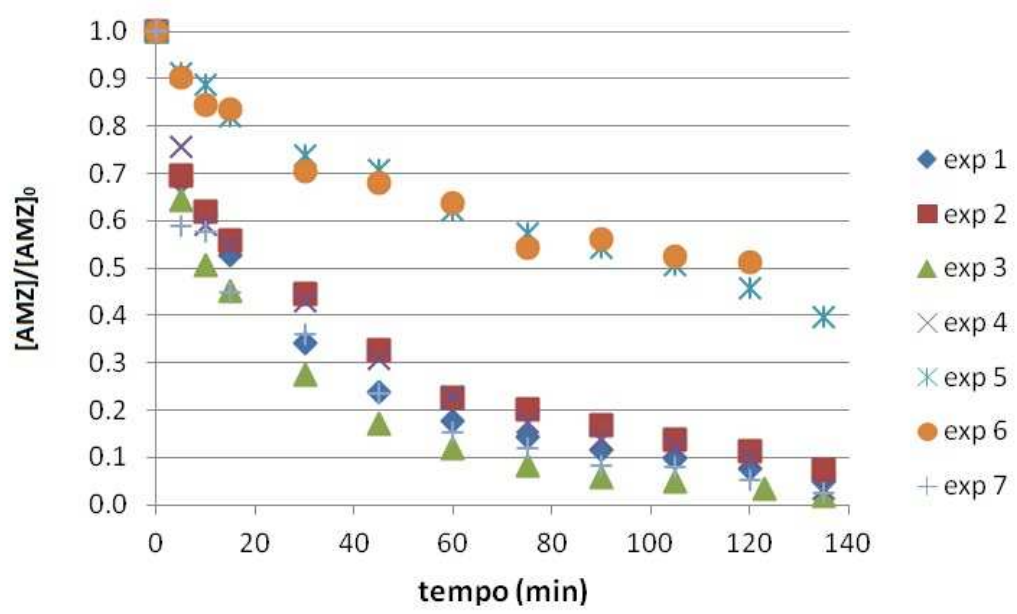

Figura 20 - Curvas de adsorção de amicarbazona (AMZ) obtidas nos experimentos realizados com recirculação da solução de amicarbazona (AMZ) à vazão de $50 \mathrm{~L} \mathrm{~h}^{-1}$ em coluna de leito fixo de carvão ativado, conforme a matriz Doehlert (Tabela 6 e Figura 8, seção 4.3.1). Condições: exp $1\left([\mathrm{AMZ}]_{0}=60 \mathrm{mg} \mathrm{L}^{-1}\right.$; massa de carvão=5,5 g), exp $2\left([\mathrm{AMZ}]_{0}=100 \mathrm{mg} \mathrm{L}^{-1}\right.$; massa de carvão=5,5 g), $\exp 3\left([\mathrm{AMZ}]_{0}=80 \mathrm{mg} \mathrm{L}^{-1} ;\right.$ massa de carvão $\left.=9,4 \mathrm{~g}\right)$, exp $4\left([\mathrm{AMZ}]_{0}=20 \mathrm{mg} \mathrm{L}^{-1} ;\right.$ massa de carvão $=5,5$ g), exp $5\left([A M Z]_{0}=40 \mathrm{mg} \mathrm{L}^{-1} \text {; massa de carvão=1,6 g), exp } 6 \text { ([AMZ }\right]_{0}=80 \mathrm{mg} \mathrm{L}^{-1}$; massa de carvão $=1,6 \mathrm{~g})$ e exp $7\left([A M Z]_{0}=40 \mathrm{mg} \mathrm{L}^{-1}\right.$; massa de carvão=9,4 g).

Tabela 9 - Respostas obtidas para os experimentos realizados com recirculação da solução de amicarbazona em coluna de leito fixo de carvão ativado, com base na matriz experimental Doehlert (Tabela 6 e Figura 8, seção 4.3.1).

\begin{tabular}{cccccccc}
\hline & $\exp \mathbf{1}$ & $\exp \mathbf{2}$ & $\exp \mathbf{3}$ & $\exp \mathbf{4}$ & $\exp \mathbf{5}$ & $\operatorname{exp~6}$ & $\operatorname{exp~7}$ \\
\hline \% máx. remoção & 95,8 & 97,5 & 98,7 & 93,4 & 78,1 & 75,3 & 97,4 \\
Tempo p/90\% da \% máx. de remoção & 77,9 & 78,0 & 67,0 & 85,0 & 90,7 & 88,6 & 71,9 \\
Tempo p/50\% da \% máx. de remoção & 11,2 & 11,4 & 9,83 & 13,6 & 37,6 & 32,9 & 10,3 \\
\% remoção em 15 minutos & 63,9 & 64,5 & 75,3 & 51,4 & 28,9 & 34,2 & 71,0 \\
\hline
\end{tabular}


Observa-se que os experimentos 5 e 6 foram os que forneceram os menores valores das respostas (em \%), o que é justificado pelo fato de que foram os que empregaram menor massa de carvão. Já os experimentos 2, 3 e 7 foram os que forneceram maior remoção porcentual do pesticida pelo carvão ativado (em \%). Exemplificando a análise estatistica desses resultados apenas para a resposta "\% máxima de remoção" (Tabela 9), obtiveram-se a Figura 21 (Diagrama de Pareto dos efeitos das variáveis independentes estudadas) e o gráfico de contornos da superfície de resposta (Figura 22).

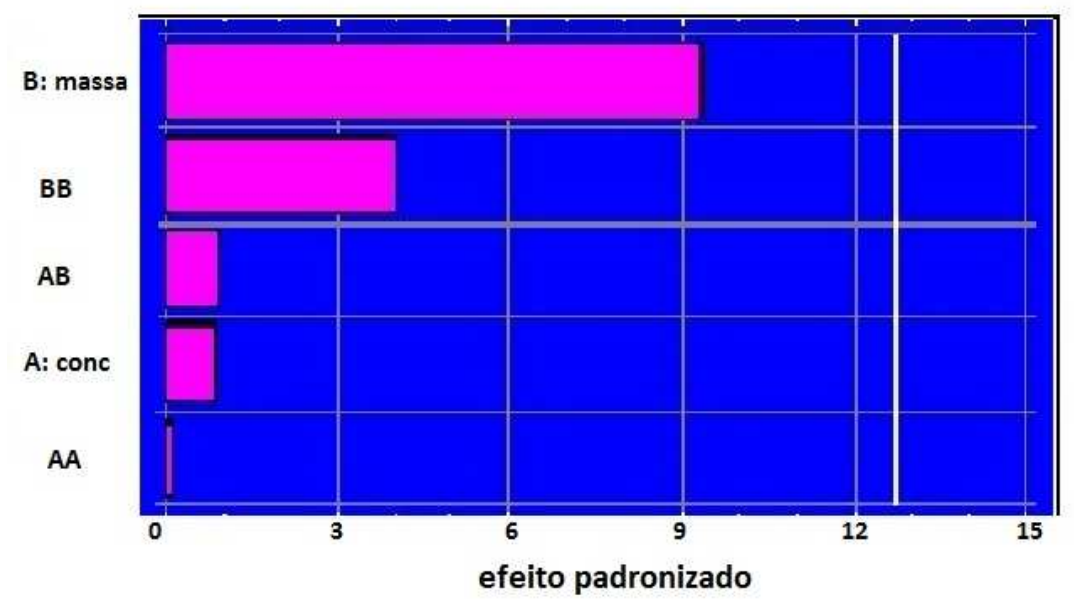

Figura 21 - Diagrama de Pareto correspondente aos resultados da matriz experimental Doehlert (Tabela 6 e Figura 7, seção 4.3.1). Valor de t de student com $7-6=1$ grau de liberdade e 95\% de confiança é 12,706. O gráfico se refere aos experimentos obtidos para a resposta " \% máxima de remoção" (Tabela 9).

O diagrama de Pareto permite fácil identificação dos efeitos mais importantes. Observa-se que nem a massa de carvão, nem a concentração da amicarbaona na solução e suas combinações apresentaram efeito estatisticamente significativo com $95 \%$ de confiança quanto à resposta analisada. No entanto, a massa de carvão apresentou o efeito mais importante. Escolheu-se essa resposta para ser analisada estatisticamente pois julgou-se ser a principal para avaliar a capacidade de adsorção do carvão ativado. 


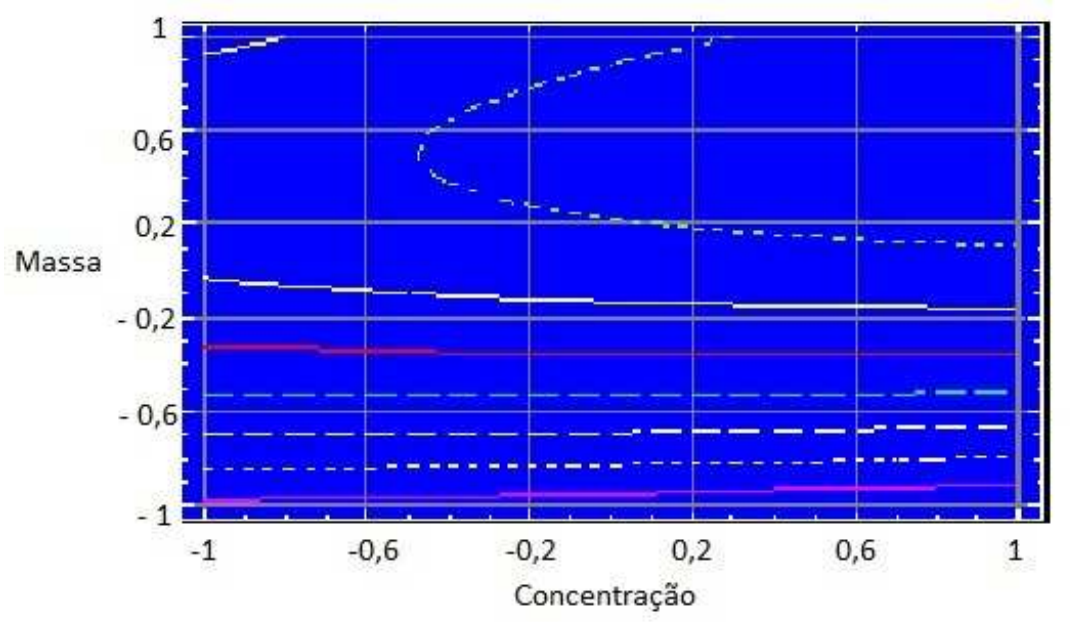

Figura 22 - Gráfico de contorno da superfície de resposta. O gráfico se refere aos experimentos obtidos para a resposta " \% máxima de remoção" (Tabela 9).

$\mathrm{Na}$ Figura 22, cada contorno corresponde a um valor constante da resposta analisada e observa-se que tomando um nível alto para massa e um nível alto para concentração, é obtido o valor codificado para a melhor massa de carvão utilizada para a elaboração da isoterma de adsorção (COMPARINI et al., 2012). Assim, realizaram-se os experimentos de adsorção cujos resultados são indicados a seguir, variando-se a concentração de pesticida, com massa de carvão ativado fixa em $7,5 \mathrm{~g}$ (valor aproximado obtido a partir da análise da superfície de resposta), novamente em triplicata, com pH natural da solução (isto é, aproximado de 7).

As curvas de adsorção obtidas para diferentes concentrações iniciais de amicarbazona encontram-se nas Figuras $23\left([\mathrm{AMZ}]_{0}=20 \mathrm{mg} \mathrm{L}^{-1}\right), 24\left([\mathrm{AMZ}]_{0}=40\right.$ $\left.\mathrm{mg} \mathrm{L}^{-1}\right), 25\left([\mathrm{AMZ}]_{0}=60 \mathrm{mg} \mathrm{L}^{-1}\right), 26\left([\mathrm{AMZ}]_{0}=80 \mathrm{mg} \mathrm{L}^{-1}\right)$ e $27\left([\mathrm{AMZ}]_{0}=100 \mathrm{mg} \mathrm{L}^{-1}\right)$ (concentrações nominais entre parênteses). $O$ mesmo procedimento foi repetido, porém ajustando-se o pH inicial em 3 e depois deixado livre (Figura 28), com a finalidade de analisar o efeito do pH no processo de adsorção. 


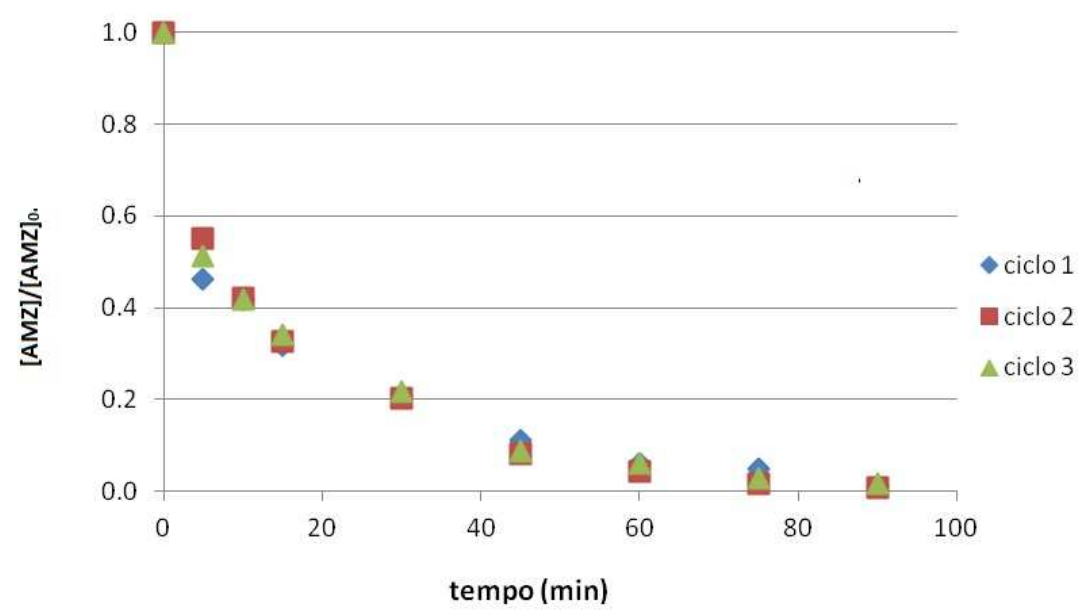

Figura 23 - Curvas de adsorção de amicarbazona (AMZ) obtidas nos experimentos realizados com recirculação da solução de amicarbazona a $50 \mathrm{~L} \mathrm{~h}^{-1}$ e $25^{\circ} \mathrm{C}$ em coluna de leito fixo contendo $7,5 \mathrm{~g}$ de carvão ativado, $\mathrm{pH}$ não ajustado no início (próximo a 7). Condições: ciclo 1: $[A M Z]_{0}=20,1 \mathrm{mg} \mathrm{L}^{-1}$; ciclo 2: $[\mathrm{AMZ}]_{0}=19,8 \mathrm{mg} \mathrm{L}^{-1}$; e ciclo 3: $[\mathrm{AMZ}]_{0}=19,7 \mathrm{mg} \mathrm{L}^{-1}$.

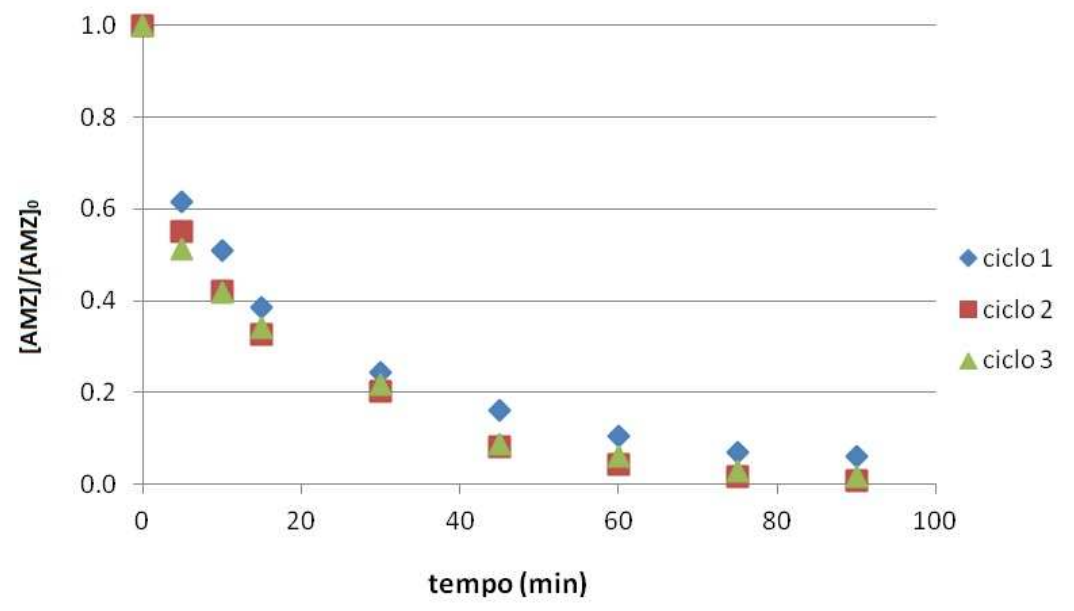

Figura 24 - Curvas de adsorção de amicarbazona (AMZ) obtidas nos experimentos realizados com recirculação da solução de amicarbazona (AMZ) a $50 \mathrm{~L} \mathrm{~h}^{-1}$ e $25^{\circ} \mathrm{C}$ em coluna de leito fixo contendo $7,5 \mathrm{~g}$ de carvão ativado, $\mathrm{pH}$ não ajustado no início (próximo a 7). Condições: ciclo 1: $[A M Z]_{0}=39,9 \mathrm{mg} \mathrm{L}^{-1}$; ciclo 2: $[A M Z]_{0}=40,2 \mathrm{mg} \mathrm{L}^{-1}$; e ciclo $3:[A M Z]_{0}=40,2 \mathrm{mg} \mathrm{L}^{-1}$. 


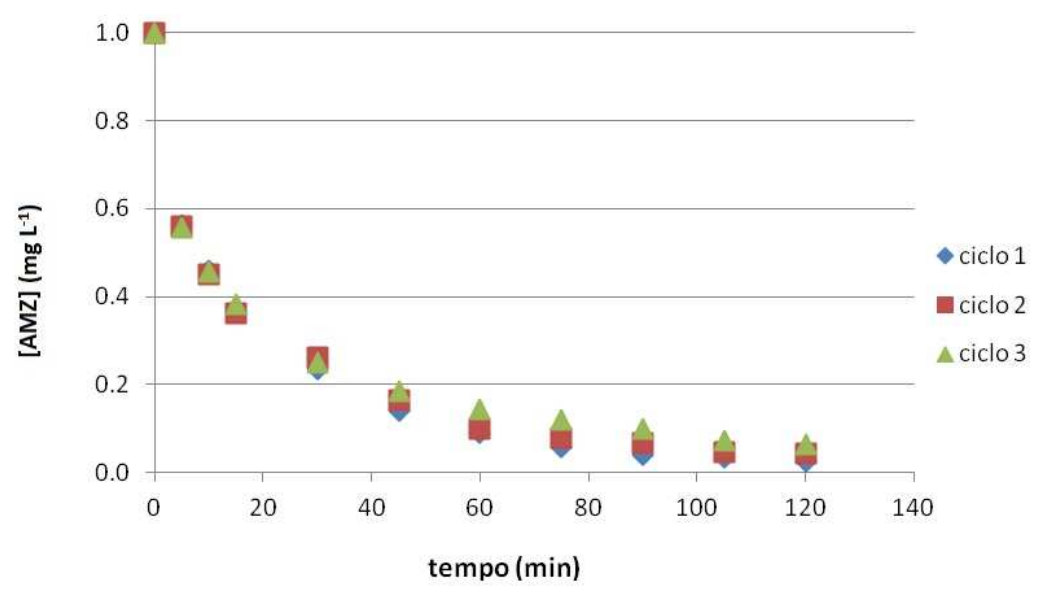

Figura 25 - Curvas de adsorção de amicarbazona (AMZ) obtidas nos experimentos realizados com recirculação da solução de amicarbazona (AMZ) a $50 \mathrm{~L} \mathrm{~h}^{-1}$ e $25^{\circ} \mathrm{C}$ em coluna de leito fixo contendo $7,5 \mathrm{~g}$ de carvão ativado, $\mathrm{pH}$ não ajustado no início (próximo a 7). Condições: ciclo 1: $[A M Z]_{0}=59,7 \mathrm{mg} \mathrm{L}^{-1}$; ciclo 2: $[A M Z]_{0}=59,5 \mathrm{mg} \mathrm{L}^{-1}$; e ciclo $3:[A M Z]_{0}=60,1 \mathrm{mg} \mathrm{L}^{-1}$.

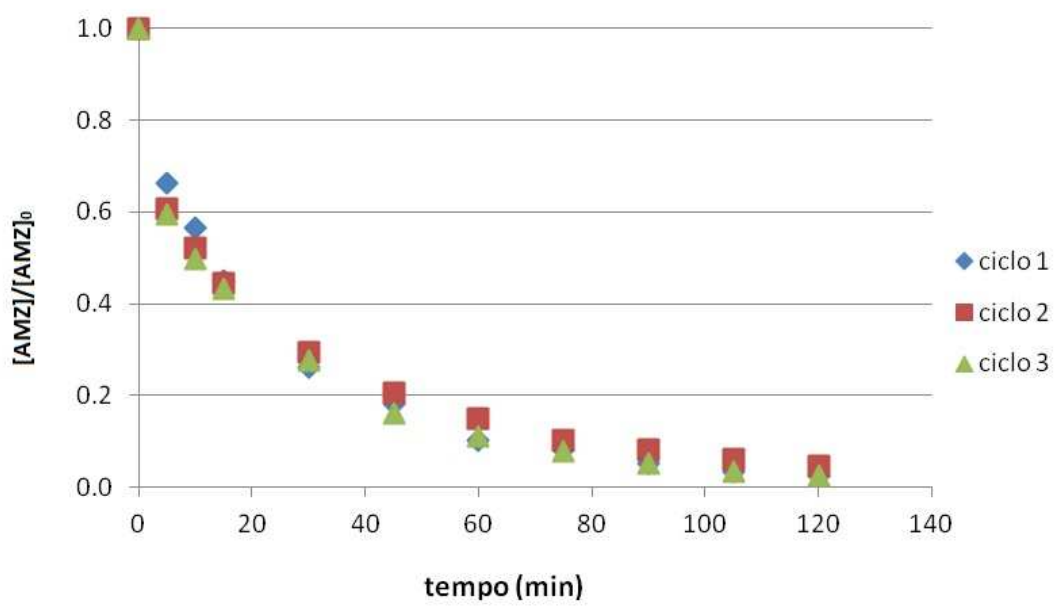

Figura 26 - Curvas de adsorção de amicarbazona (AMZ) obtidas nos experimentos realizados com recirculação da solução de amicarbazona (AMZ) a $50 \mathrm{~L} \mathrm{~h}^{-1}$ e $25^{\circ} \mathrm{C}$ em coluna de leito fixo contendo $7,5 \mathrm{~g}$ de carvão ativado, $\mathrm{pH}$ não ajustado no início (próximo a 7). Condições: ciclo 1: $[\mathrm{AMZ}]_{0}=78,9 \mathrm{mg} \mathrm{L}^{-1}$; ciclo 2: $[\mathrm{AMZ}]_{0}=79,3 \mathrm{mg} \mathrm{L}^{-1}$; e ciclo 3: $[\mathrm{AMZ}]_{0}=79,2 \mathrm{mg} \mathrm{L}^{-1}$. 


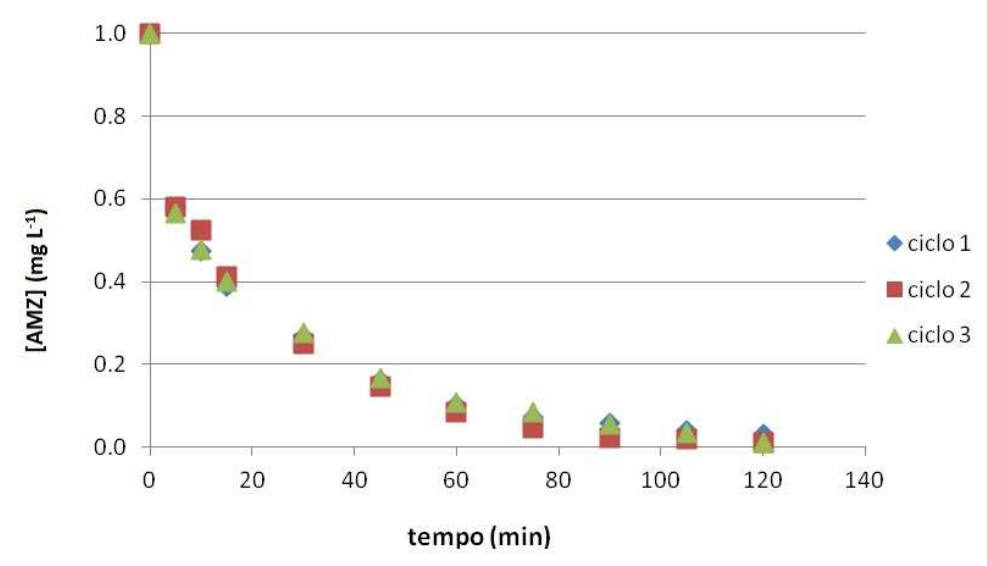

Figura 27 - Curvas de adsorção de amicarbazona (AMZ) obtidas nos experimentos realizados com recirculação da solução de amicarbazona (AMZ) a $50 \mathrm{~L} \mathrm{~h}^{-1}$ e $25^{\circ} \mathrm{C}$ em coluna de leito fixo contendo $7,5 \mathrm{~g}$ de carvão ativado, $\mathrm{pH}$ não ajustado no início (próximo a 7). Condições: ciclo 1: $[A M Z]_{0}=100,4 \mathrm{mg} \mathrm{L}^{-1}$; ciclo 2: $[A M Z]_{0}=100,1 \mathrm{mg} \mathrm{L}^{-1}$; e ciclo $3:[A M Z]_{0}=99,7 \mathrm{mg} \mathrm{L}^{-1}$.

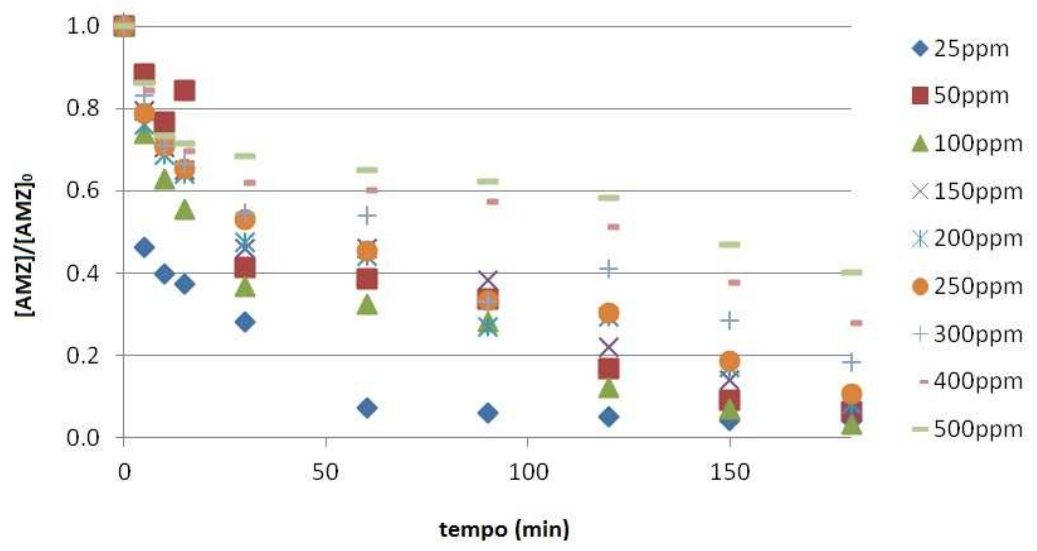

Figura 28 - Curvas de adsorção de amicarbazona (AMZ) em carvão ativado obtidas nos experimentos realizados com recirculação da solução de amicarbazona a $50 \mathrm{~L} \mathrm{~h}^{-1}$ e $25^{\circ} \mathrm{C}$ em coluna de leito fixo contendo $7,5 \mathrm{~g}$ de carvão ativado, $\mathrm{pH}$ ajustado inicialmente para 3 .

As isotermas de adsorção (Figura 29) foram obtidas segundo o procedimento descrito na seção 4.3 .1 com base na análise dos resultados das curvas de adsorção anteriores. Observa-se que um $\mathrm{pH}$ ácido exerce efeito importante sobre o processo de adsorção, já que uma maior quantidade de pesticida foi adsorvida para uma mesma massa de carvão. Isto pode ser devido ao fato de que a solubilidade do pesticida em solução e a carga dos sítios ativos na superfície do material podem mudar dependendo do valor do $\mathrm{pH}$. Em meio ácido ( $\mathrm{pH}=3$ ), a remoção do pesticida por adsorção no carvão ativado foi melhor e 
mais rápida, enquanto para os experimentos sem controle de $\mathrm{pH}$ (próximo a 7), a remoção do pesticida foi menor.

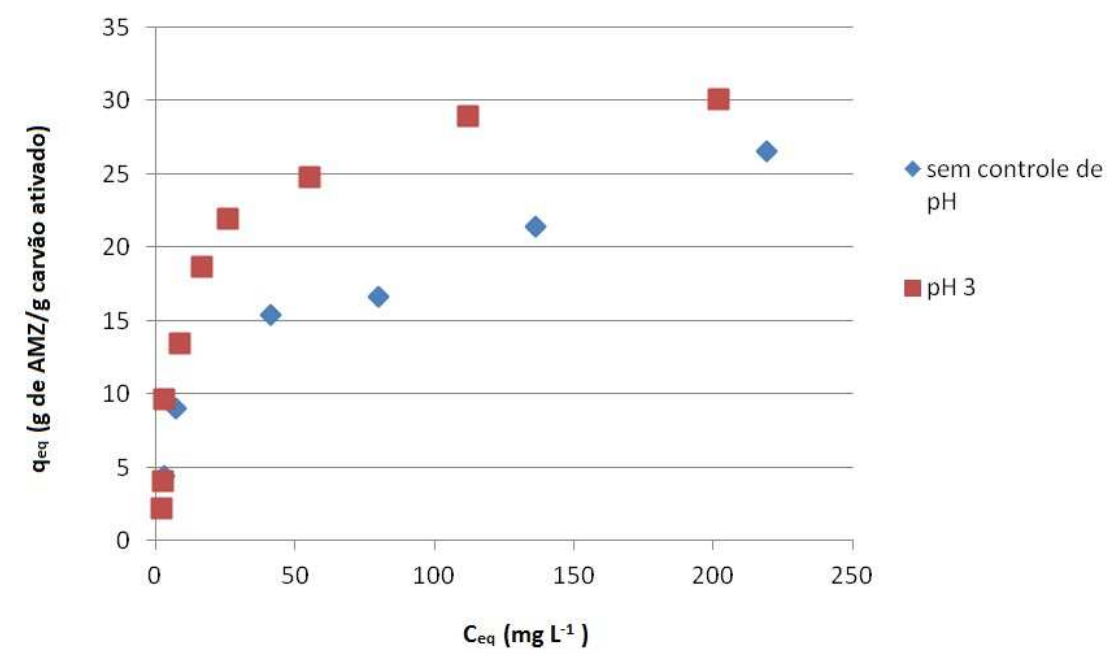

Figura 29 - Isotermas de adsorção de amicarbazona (AMZ) obtidas a $25^{\circ} \mathrm{C}$, para diferentes condições de $\mathrm{pH}$ inicial (sem ajuste com pH próximo a 7 e com ajuste em $\mathrm{pH}=3$ ).

Assim, seguindo o planejamento experimental, observam-se comportamentos diferentes para as duas isotermas: a elaborada sem ajuste inicial de $\mathrm{pH}$ sugere que ocorre adsorção em múltiplas camadas, enquanto que a elaborada com ajuste de pH leva a crer que a saturação completa foi alcançada, havendo apenas uma única camada de adsorbato no carvão ativado.

\subsubsection{Saturação do carvão ativado}

Obtidas as isotermas de adsorção, deu-se início ao processo de saturação do carvão ativado Filtrasorb 100 em coluna de leito fixo (Figura 5). Buscou-se seguir as informações indicadas pela Figura 29, partindo-se de soluções de amicarbazona com concentração de $500 \mathrm{mg} \mathrm{L}^{-1}$ e $10 \mathrm{~g}$ de carvão ativado. Acreditava-se que somente um ciclo de adsorção de 2 horas fosse necessário para realizar a saturação por completo do carvão ativado, porém, como pode ser observado na Figura 30, somente após 4 ou mais ciclos os resultados passaram a 
ser mais estáveis, ou seja, a variação na capacidade de adsorção do carvão ficou pequena, sugerindo sua saturação. Por outro lado, caso os ciclos 9 e 10 tivessem apresentado porcentagens de remoção próximas entre si, poder-se-ia afirmar ter alcançado a saturação do carvão ativado. A diferença entre as remoções obtidas entre o $9^{\circ}$ e $10^{\circ}$ ciclos ( $7 \%$ e $4 \%$, respectivamente), porém, sugere que essa situação ainda não fora alcançada sendo, portanto, necessários mais ciclos de adsorção. Dessa forma, a seleção do número de ciclos de adsorção empregados no trabalho foi baseada em um compromisso entre a saturação real (que, como sugerem os resultados, deve ser alcançada somente após um número muito grande de ciclos) e fatores como tempo de realização dos experimentos, disponibilidade de reagentes e custo experimental (por exemplo, análise no HPLC). Nesse sentido, optou-se por padronizar todos os experimentos apresentados a seguir considerando um único ciclo de adsorção.

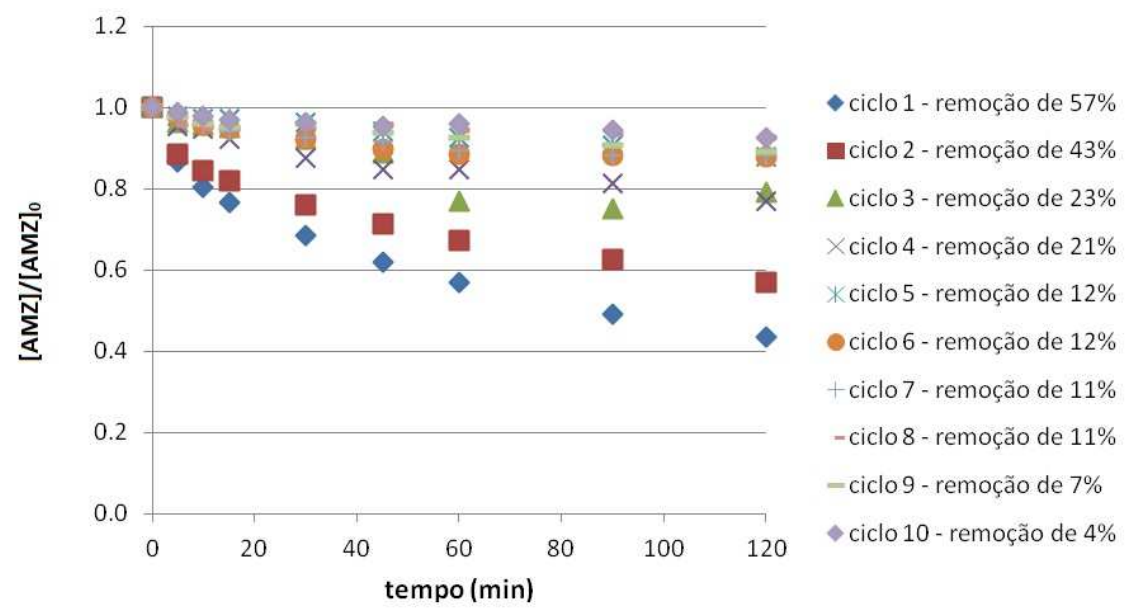

Figura 30 - Ensaios de saturação do carvão ativado, utilizando uma solução de amicarbazona (AMZ) com concentração de $500 \mathrm{mg} \mathrm{L}^{-1}$ para $10 \mathrm{~g}$ de carvão ativado. Experimentos realizados em coluna de leito fixo (Figura 5) e com pH próximo a 7.

\subsection{Regeneração pelo Processo Oxidativo $\mathrm{H}_{2} \mathrm{O}_{2} / \mathrm{UV}$}

Avaliou-se a regeneração do carvão ativado propriamente dita, buscandose o desempenho mais estendido para o mesmo, sem prejuízo quanto à 
capacidade de adsorção, que já se mostrou adequada para o tratamento proposto. O processo utilizado foi o mesmo descrito na seção 4.3.3: a adsorção foi feita por 2 horas, a partir de solução de amicarbazona de $500 \mathrm{mg} \mathrm{L}^{-1}$, seguida pela regeneração pelo do processo $\mathrm{H}_{2} \mathrm{O}_{2} / \mathrm{UV}$ irradiado por meio de uma lâmpada UVC de 125 W (emissão em 253,7 nm), com alimentação de solução de peróxido de hidrogênio (concentração mol/L) à vazão de $5 \mathrm{~mL} \mathrm{~h}^{-1}$, por um período de 4 horas - considerado um tempo bom para a reação. Em todos os casos, os experimentos foram realizados com recirculação de solução em coluna de leito fixo, contendo $10 \mathrm{~g}$ de carvão ativado, associada ao reator fotoquímico (Figura 6).

A Figura 31 mostra os resultados obtidos para esse primeiro teste de regeneração. $\mathrm{O}$ ciclo 1 corresponde à primeira etapa de $2 \mathrm{~h}$ de adsorção realizada com o carvão ativado que ainda não havia passado por nenhuma forma de tratamento para regeneração; e os ciclos 2 e 3 correspondem à segunda e terceira etapas de 2 horas de adsorção cada uma, respectivamente, posteriores a um ciclo de 4 horas de regeneração, ou seja, o processo todo consistiu em: adsorção (ciclo 1) - regeneração - adsorção (ciclo 2) - regeneração - adsorção (ciclo 3). Esse mesmo procedimento será observado nas Figuras 31 a 38.

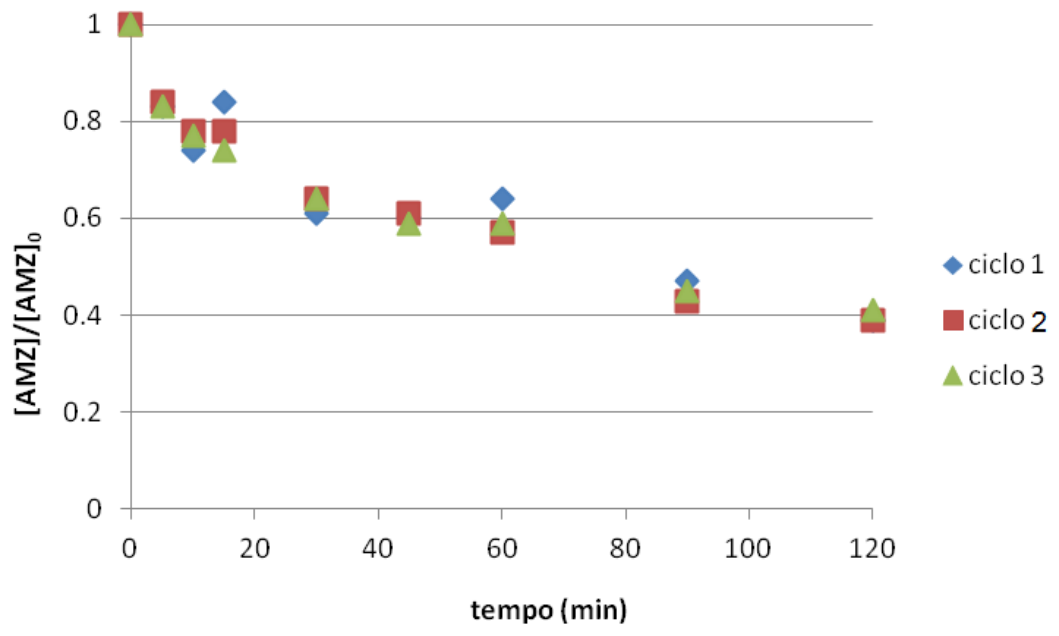

Figura 31 - Resultados dos ensaios de adsorção/regeneração. Regeneração do carvão ativado em cada ciclo por meio de processo oxidativo avançado $\mathrm{H}_{2} \mathrm{O}_{2} / \mathrm{UV}$, com lâmpada UVC de $125 \mathrm{~W}$ de potência e com alimentação de peróxido à vazão de $5 \mathrm{~mL} \mathrm{~h}^{-1}$, por um período de 4 horas e $\mathrm{pH}$ próximo a 7. 
Observou-se uma redução discreta da remoção do pesticida, isto é, da adsorção pelo CA - 60,3\% (ciclo 1), 59,8\% (ciclo 2) e 56,3\% (ciclo 3) de remoção, calculados pela diferença entre as concentrações inicial e final e o resultado dividido pela concentração inicial, ou seja, é a quantidade (em \%) de contaminante que foi removida após 2 horas de adsorção - após 2 ciclos de regeneração pelo processo oxidativo. Os resultados (Figura 32), que foram determinados por cromatografia líquida (medidos em $\mathrm{mg} \mathrm{L}^{-1}$ ), indicaram que houve regeneração do carvão, uma vez que as curvas de [AMZ]/[AMZ] são praticamente coincidentes em todo tempo de experimento, o que mostra que o CA teve sua capacidade de adsorver a amicarbazona restaurada após a regeneração pelo processo foto-oxidativo. Isso pode ser melhor compreendido observando que, na Fig. 30, houve uma perda de desempenho de CA após $02^{\circ}$ ciclo de adsorção.

A existência de peróxido de hidrogênio residual (em excesso) foi avaliada conforme o método do metavanadato de amônio (descrito na seção 4.3.2), que mostrou que nem todo o peróxido adicionado estaria sendo consumido pela reação de oxidação da amicarbazona adsorvida pelo carvão ativado.

Num segundo momento o mesmo procedimento foi realizado, com a diferença de que $5 \mathrm{~mL}$ de $\mathrm{H}_{2} \mathrm{O}_{2}$ foram adicionados no início da reação, além dos 5 $\mathrm{mL} \mathrm{h} \mathrm{h}^{-1}$ já previstos, para que houvesse, dessa forma, peróxido em excesso (avaliado segundo o método do metavanadato de amônio) com a intenção de se ter certeza de que a relação estequiométrica entre oxidante e pesticida fora alcançada. Novamente, observou-se redução discreta da capacidade de adsorção pelo CA - 44,0\%, 43,9\% e 40,3\%. - após 2 ciclos de regeneração pelo processo oxidativo. Os resultados (Figura 32) indicaram que também houve regeneração do carvão ativado, já que se observa uma manutenção no poder de adsorção após ciclos de regeneração consecutivos. 


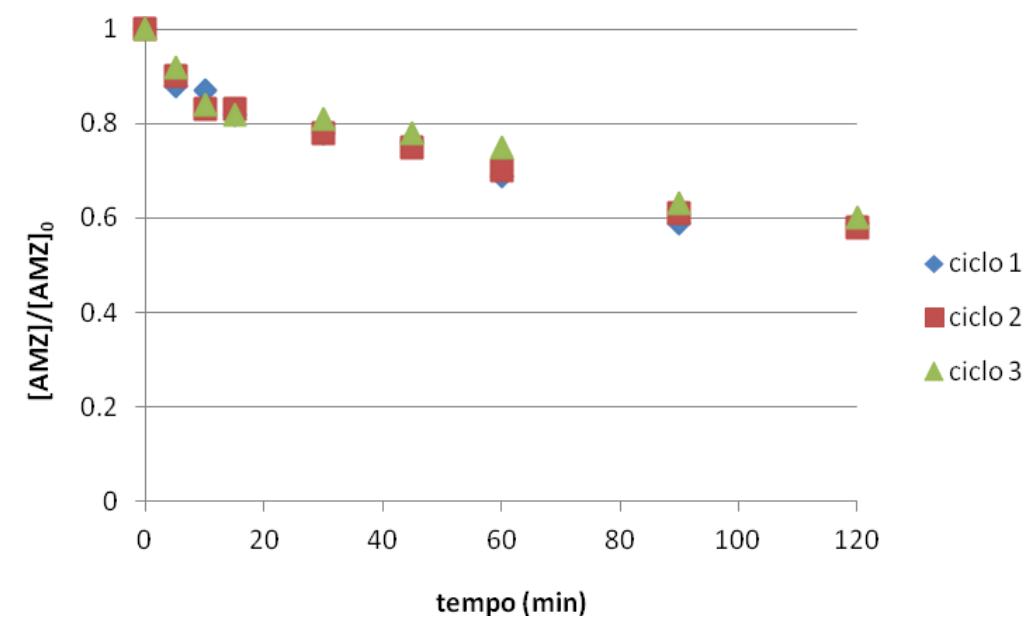

Figura 32 - Resultados dos ensaios de adsorção/regeneração. Regeneração do carvão ativado em cada ciclo por meio de processo oxidativo avançado $\mathrm{H}_{2} \mathrm{O}_{2} / \mathrm{UV}$, com uma lâmpada de $125 \mathrm{~W}$ de potência e com alimentação de peróxido na vazão de $5 \mathrm{~mL} \mathrm{~h}^{-1}$, sendo que outros $5 \mathrm{~mL}$ de peróxido foram adicionados no tempo zero, totalizando $25 \mathrm{~mL}$ de peróxido, por um período de 4 horas e pH próximo a 7.

\subsection{Regeneração por peroximonossulfato de potássio (PMS)}

O PMS (peroximonossulfato de potássio), cujas reações de oxidação em que participa são ainda pouco conhecidas, é um oxidante novo e por isso o interesse de estudá-lo no presente trabalho.

O procedimento utilizado foi o mesmo apresentado no item 4.3.3., variando-se a proporção oxidante/contaminante e o tempo de regeneração, ou seja, o processo combinado (duas etapas) consiste primeiro em passar a solução contendo o herbicida ([AMZ $\left.]_{0}=200 \mathrm{mg} \mathrm{L}^{-1}\right)$ em carvão ativado por um período de $2 \mathrm{~h}$ (etapa de adsorção), após o que segue a etapa de tratamento do mesmo por PMS. Ao contrário dos experimentos discutidos na seção 5.4 , todos os experimentos com PMS foram realizados em frascos sob agitação, contendo $1 \mathrm{~g}$ de carvão ativado.

Nos experimentos apresentados nas Figuras 33, 34 e 35, a proporção molar oxidante/contaminante foi de 1:1 e o tempo foi variado (1, 2 e 4 horas), enquanto que nos experimentos apresentados nas Figuras 36, 37 e 38 a relação molar oxidante/contaminante foi de 2:1 e o tempo de regeneração também foi variado (1, 2 e 4 horas). 
Como pode ser observado na Figura 33, nos ciclos de adsorção 2 e 3 observou-se piora na capacidade de remoção do contaminante, quando comparados ao primeiro ciclo, o que leva a crer que não houve regeneração.

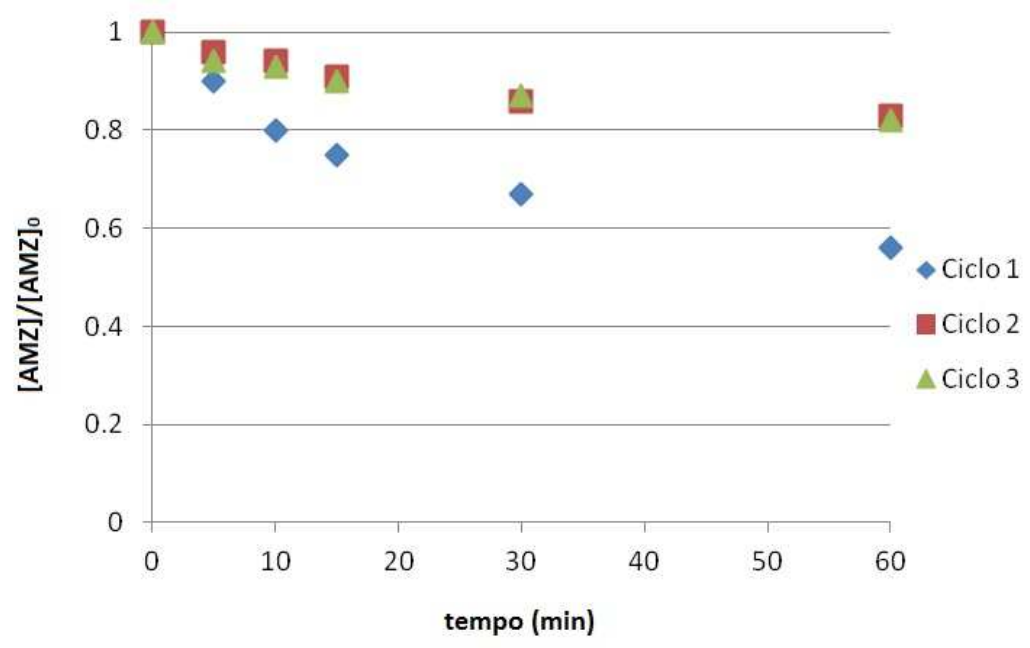

Figura 33 - Resultados dos ensaios de adsorção/regeneração. Regeneração do carvão ativado por meio de processo oxidativo avançado com PMS, por 1 hora, na proporção molar oxidante/contaminante de 1:1 e pH próximo a 7.

Na Figura 34 pode-se observar que no ciclo 2 ocorreu maior adsorção nos primeiros minutos, quando comparado ao ciclo 1, porém no ciclo 3 houve redução da capacidade de adsorção.

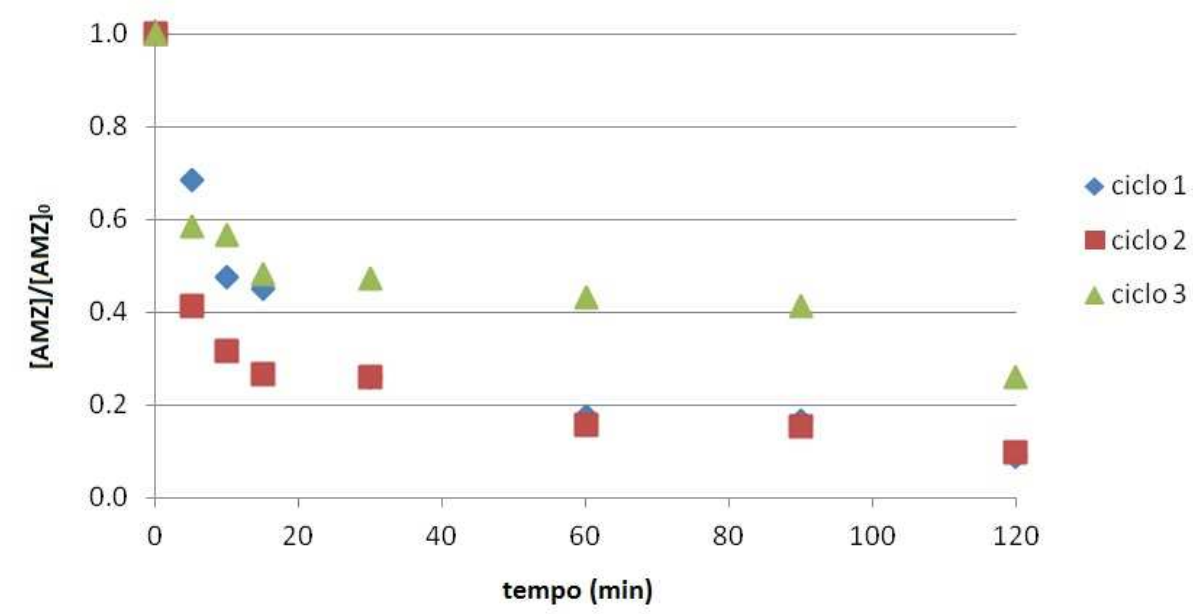

Figura 34 - Resultados dos ensaios de adsorção/regeneração. Regeneração do carvão ativado, por meio de processo oxidativo avançado com PMS, por 2 horas, na proporção molar oxidante/contaminante de 1:1 e pH próximo a 7 . 
Nos ciclos 2 e 3 da Figura 35 obteve-se um ganho significativo na adsorção quando comparados ao ciclo inicial, enquanto que na Figura 36 observa-se que nesses ciclos adsorveu-se menos no final do processo de adsorção para tempo superior a 90 minutos de contato. No começo da adsorção as curvas obtidas para os três ciclos ficaram parecidas.



Figura 35 - Resultados dos ensaios de adsorção/regeneração. Regeneração do carvão ativado, por meio de processo oxidativo avançado com PMS, por 4 horas, na proporção molar oxidante/contaminante de 1:1 e pH próximo a 7.

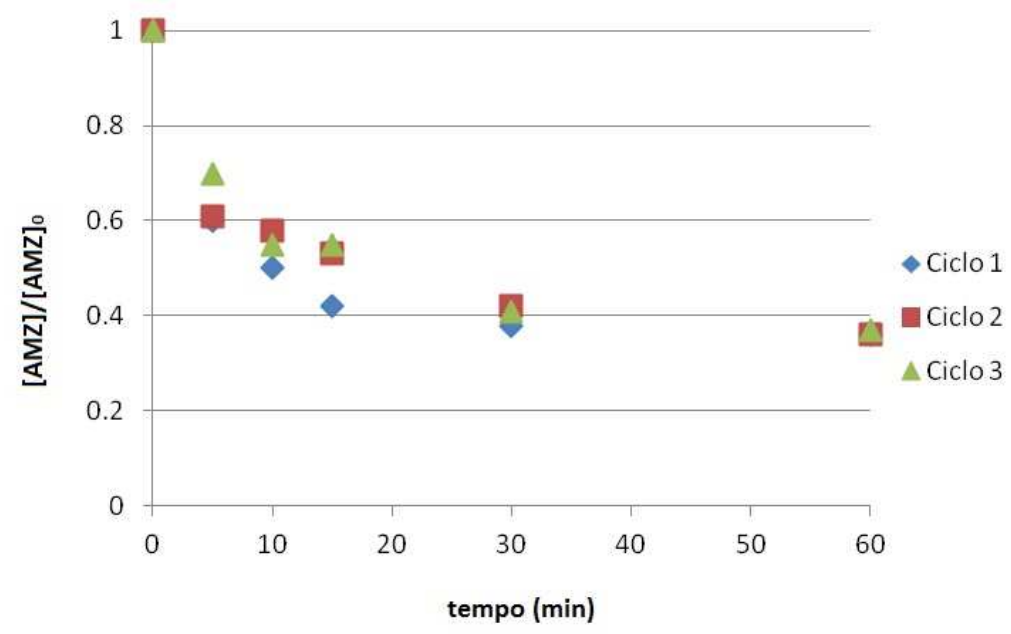

Figura 36 - Resultados dos ensaios de adsorção/regeneração. Regeneração do carvão ativado, por meio de processo oxidativo avançado com PMS, por 1 hora, na proporção molar oxidante/contaminante de 2:1 e pH próximo a 7. 
A Figura 37 também indica melhora na capacidade de adsorção, para os ciclos 2 e 3, semelhante ao que se observa na Figura 35.

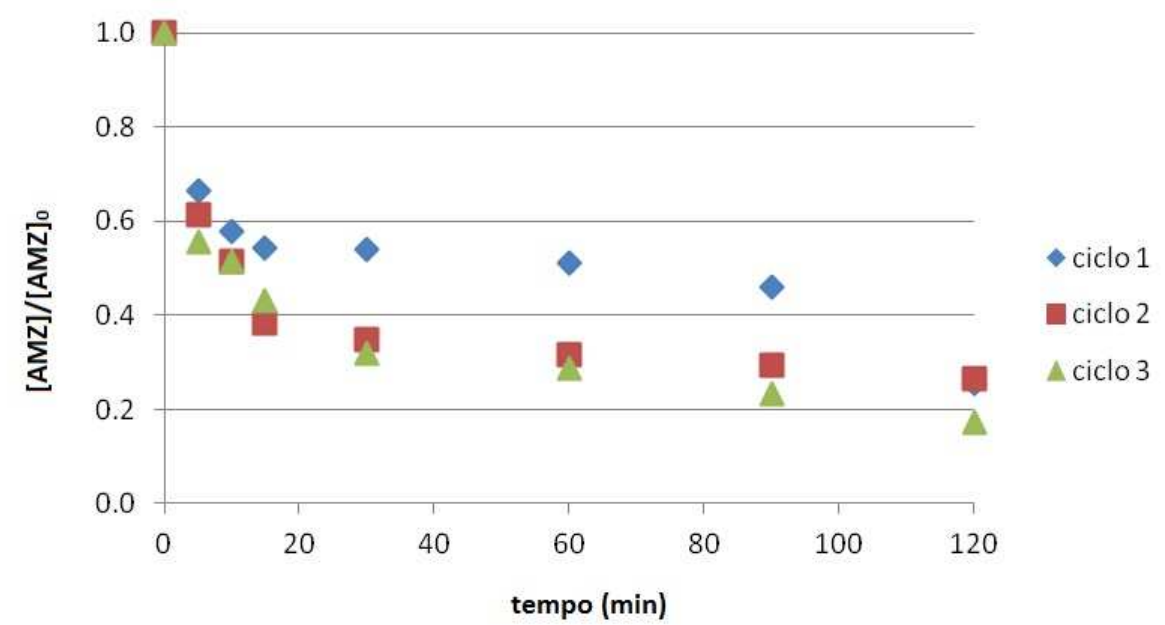

Figura 37 - Resultados dos ensaios de adsorção/regeneração. Regeneração do carvão ativado, por meio de processo oxidativo avançado com PMS, por 2 horas, na proporção molar oxidante/contaminante de 2:1 e pH próximo a 7.

Por fim a Figura 38 indica não ter havido grandes diferenças para os ciclos 1 e 2, porém o ciclo 3 apresentou capacidade de adsorção aumentada quando comparada à do ciclo de adsorção inicial (ciclo 1).

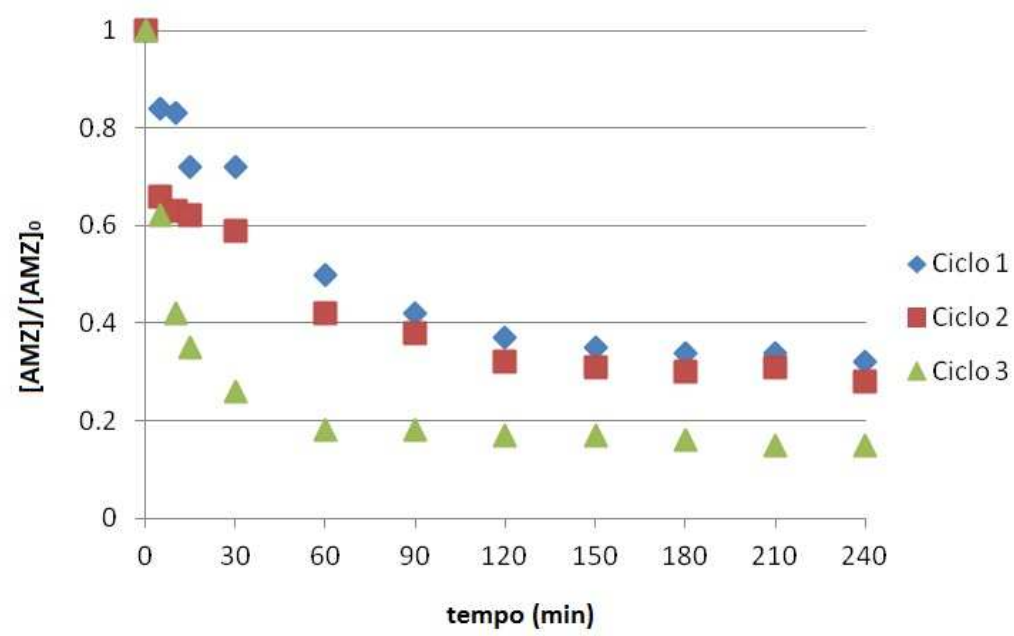

Figura 38 - Resultados dos ensaios de adsorção/regeneração. Regeneração do carvão ativado, por meio de processo oxidativo avançado com PMS, por 4 horas, na proporção molar oxidante/contaminante de 2:1 e pH próximo a 7. 
A Figura 39 mostra três ciclos consecutivos (de duas horas cada) de adsorção, sem a etapa de regeneração entre eles, com a finalidade de ser um branco para avaliar o desempenho das etapas de regeneração. Mesmo após 3 ciclos de adsorção consecutivos, sem regeneração, a capacidade de remoção do herbicida pelo carvão ativado permaneceu praticamente a mesma.

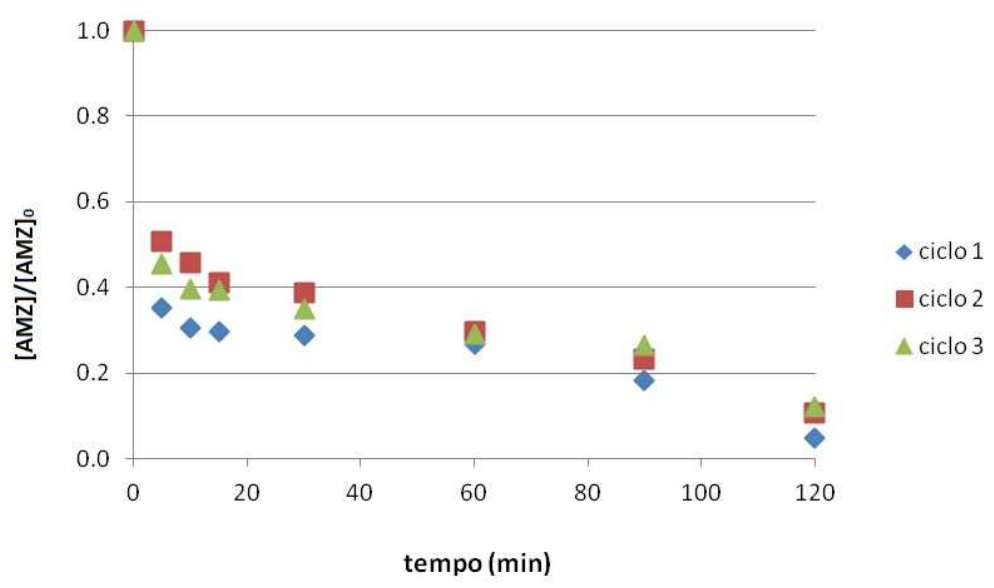

Figura 39 - Ciclos de adsorção do carvão ativado sem regeneração

A partir desses resultados, a regeneração usando PMS é aparentemente efetiva, embora seja difícil caracterizá-la precisamente devido à pequena reprodutibilidade das curvas de adsorção obtidas no primeiro ciclo. Isso pode ser devido à própria amostra de carvão ativado ou às condições de agitação dos frascos nos experimentos.

Os resultados anteriores não deixam claro se a melhor opção consiste em aumentar o tempo de duração da regeneração ou a proporção molar entre o oxidante e a amicarbazona, já que em ambos os casos é possível regenerar o carvão ativado. Por outro lado, considerando a questão operacional, acredita-se ser preferível realizar a regeração em tempos menores, o que sugere empregar maiores concentrações de oxidante.

Em um segundo momento, repetiu-se o processo simultâneo de adsorção regeneração - adsorção (primeiro passou-se o efluente contaminado pela etapa de adsorção em carvão ativado até saturação deste, após o que se seguiu a 
etapa de tratamento do carvão por processo oxidativo e então um novo processo de adsorção). Nesse caso, os experimentos também foram realizados em frascos sob agitação, porém utilizando-se amostras de carvão ativado (1 g) que já haviam sido previamente expostas a soluções de amicarbazona, de modo que estes carvões já continham pesticida adsorvido. Dessa forma, buscou-se assegurar ter atingido praticamente a saturação total do carvão antes da realização dos experimentos.

Repetiram-se os experimentos de regeneração por meio do processo oxidativo avançado PMS por 2 horas, variando-se a proporção molar oxidante/contaminante em 2:1, 1:1 e 1:2 (Figuras 40, 41 e 42, respectivamente). Os resultados dessas figuras sugerem que não houve melhora significativa na capacidade de adsorção do carvão ativado após ciclos consecutivos de adsorção - regeneração, já que a pequena diferença observada pode estar associada ao erro experimental e analítico.

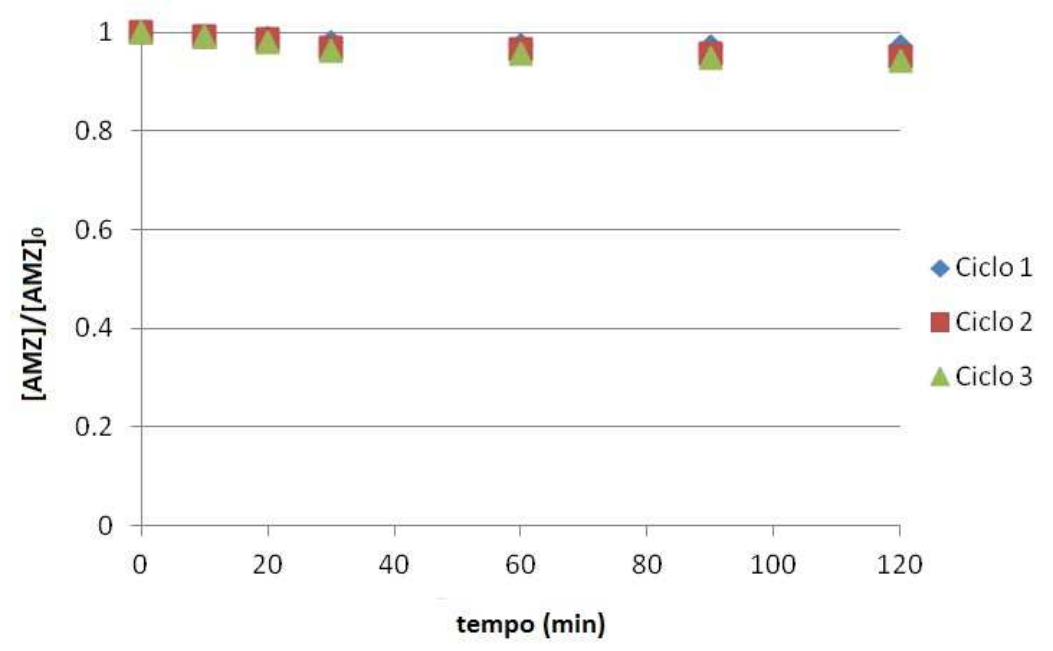

Figura 40 - Resultados dos ensaios de adsorção/regeneração. Regeneração do carvão ativado, por meio de processo oxidativo avançado com PMS, por 2 horas, na proporção molar oxidante/contaminante de 2:1 e pH próximo a 7. 


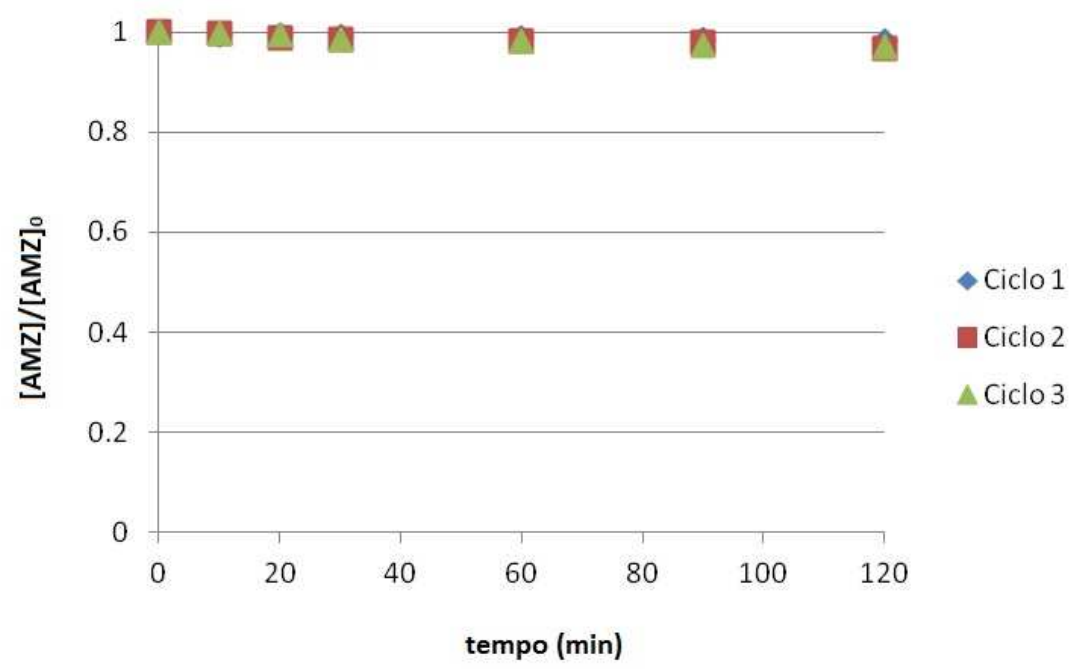

Figura 41 - Resultados dos ensaios de adsorção/regeneração. Regeneração do carvão ativado, por meio de processo oxidativo avançado com PMS, por 2 horas, na proporção molar oxidante/contaminante de 1:1 e pH próximo a 7.

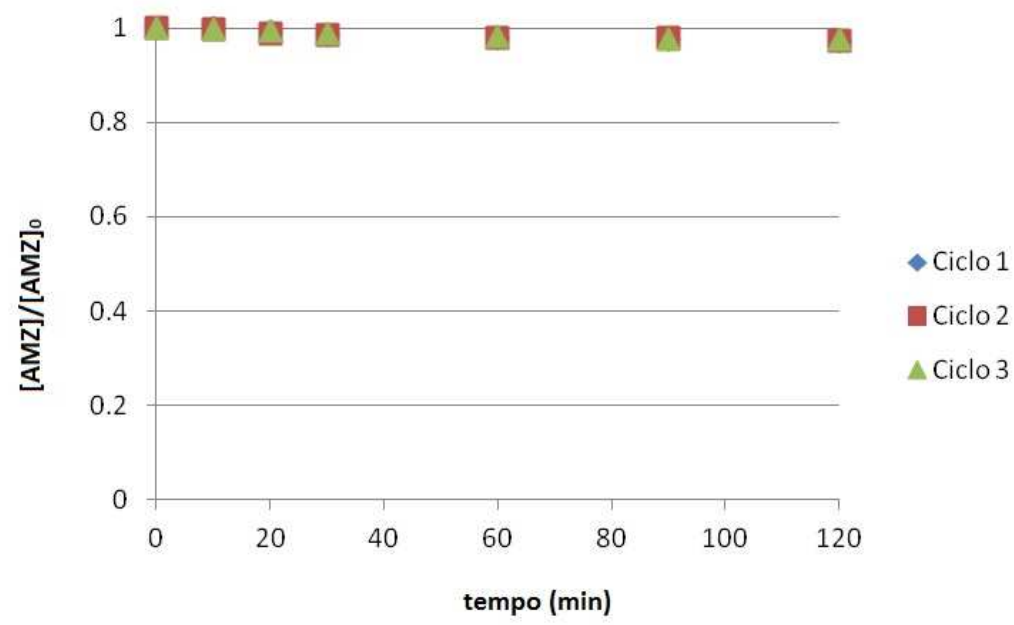

Figura 42 - Resultados dos ensaios de adsorção/regeneração. Regeneração do carvão ativado, por meio de processo oxidativo avançado com PMS, por 2 horas, na proporção molar oxidante/contaminante de 1:2 e pH próximo a 7.

Para analisar a influência da aplicação de um excesso de oxidante, realizaram-se experimentos, também com 2 horas de duração, variando-se a proporção molar oxidante/contaminante entre 10:1, 20:1, 30:1 e 40:1 (Figuras 43, 44, 45 e 46, respectivamente). Nas Figuras 43 e 44, como aconteceu com os experimentos das Figuras 40 a 42, não se observou diferença significativa quanto ao desempenho da adsorção. Contudo os experimentos com proporção molar oxidante/contaminante de 30:1 e de 40:1 (Figuras 45 e 46) apresentaram melhor 
desempenho quanto à adsorção, principalmente quando se compara o $3^{\circ}$ ciclo de adsorção com o $1^{\circ}$ ciclo.

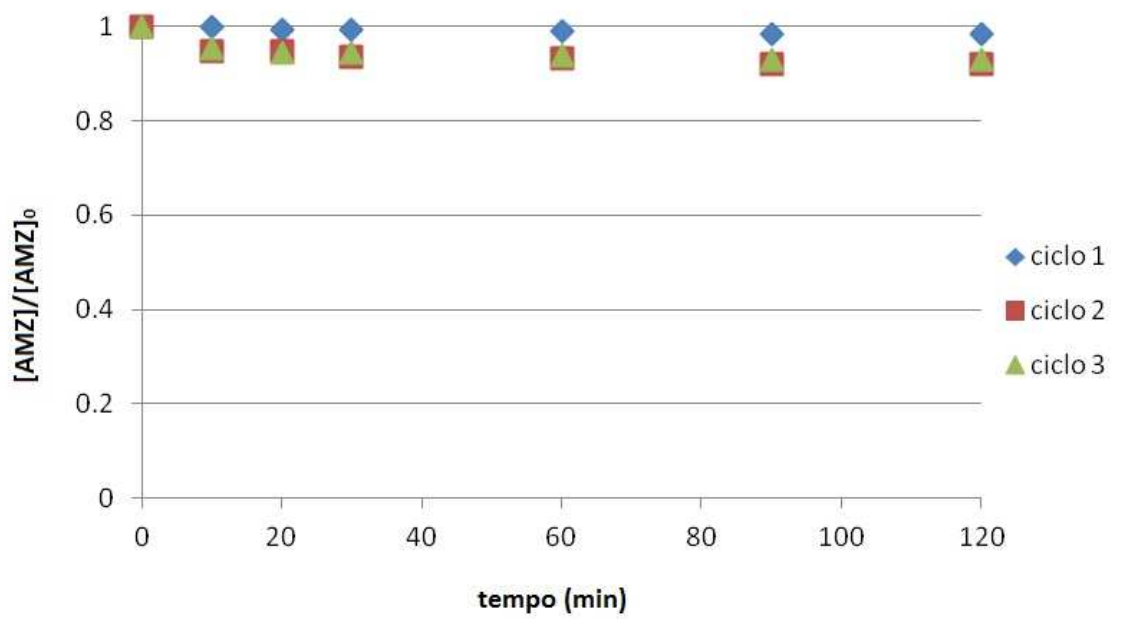

Figura 43 - Resultados dos ensaios de adsorção/regeneração. Regeneração do carvão ativado, por meio de processo oxidativo avançado com PMS, por 2 horas, na proporção molar oxidante/contaminante de 10:1 e pH próximo a 7.

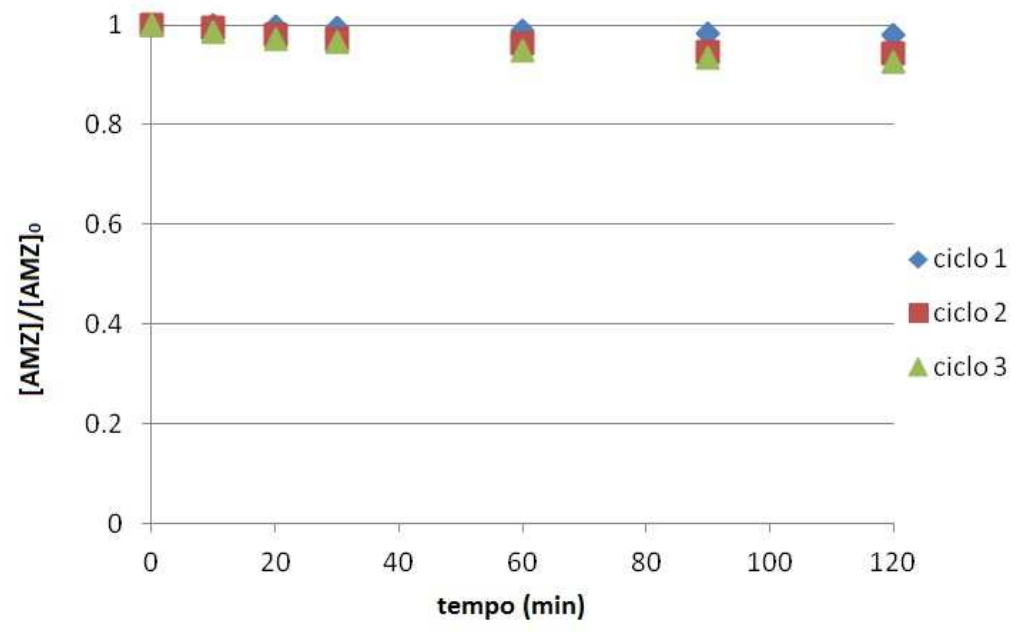

Figura 44 - Resultados dos ensaios de adsorção/regeneração. Regeneração do carvão ativado, por meio de processo oxidativo avançado com PMS, por 2 horas, na proporção molar oxidante/contaminante de 20:1 e pH próximo a 7. 


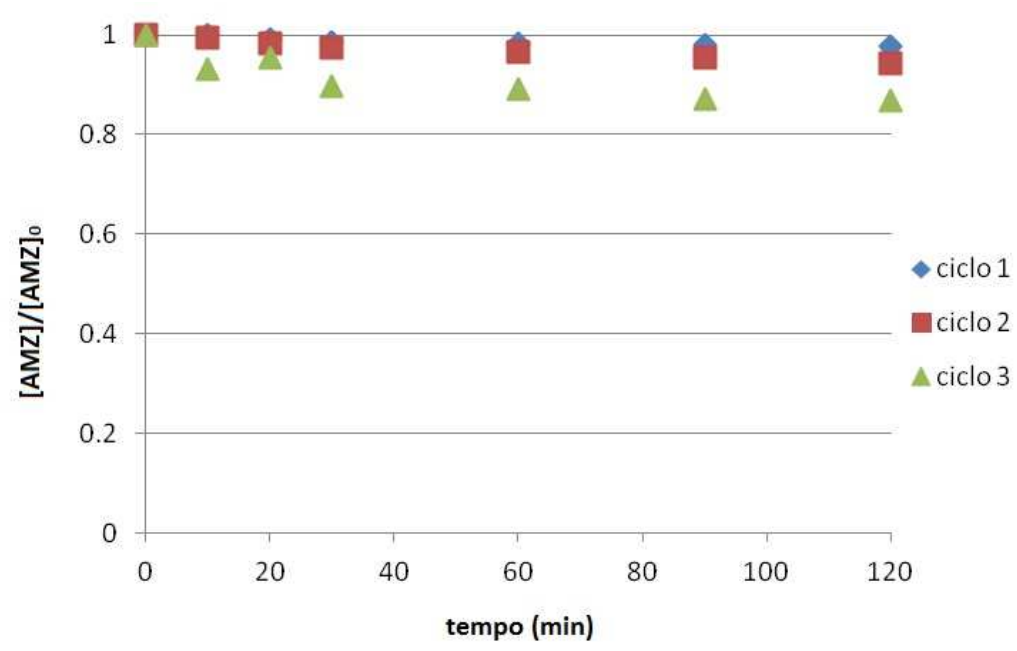

Figura 45 - Resultados dos ensaios de adsorção/regeneração. Regeneração do carvão ativado, por meio de processo oxidativo avançado com PMS, por 2 horas, na proporção molar oxidante/contaminante de 30:1 e pH próximo a 7.

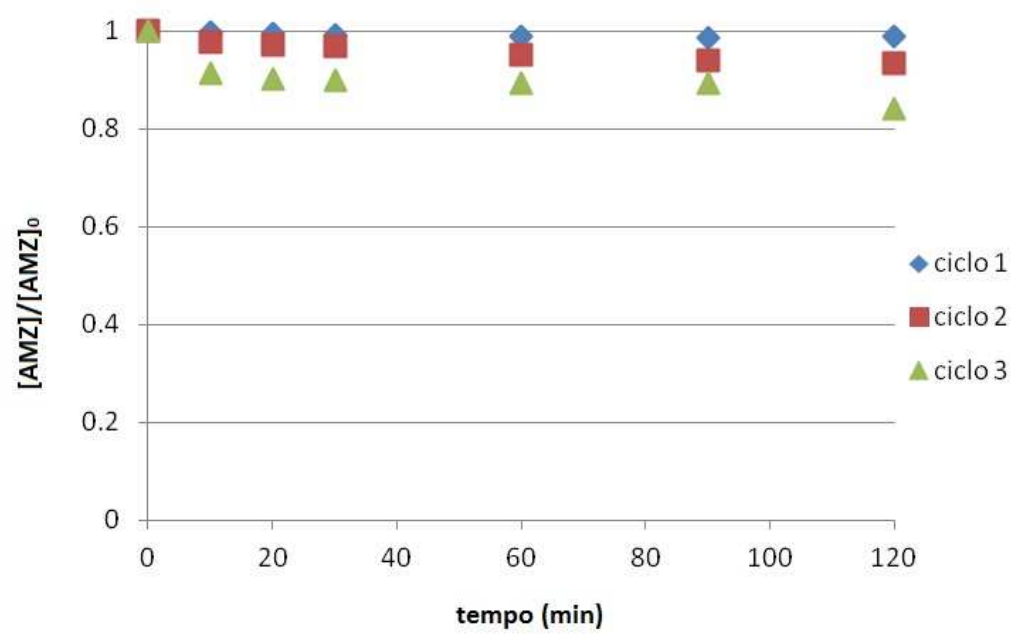

Figura 46 - Resultados dos ensaios de adsorção/regeneração. Regeneração do carvão ativado, por meio de processo oxidativo avançado com PMS, por 2 horas, na proporção molar oxidante/contaminante de 40:1 e pH próximo a 7.

Repetiram-se os mesmos três experimentos variando-se a proporção molar oxidante/contaminente em 2:1, 1:1 e 1:2, porém agora por um tempo de 12 horas (Figuras 47, 48 e 49, respectivamente). Observou-se que o tempo de regeneração, aliado à proporção oxidante/contaminente mais alta, influenciou positivamente o desempenho do carvão, ou seja, levou ao aumento de sua capacidade de adsorção da amicarbazona, fato que é confirmado na Figura 50, quando se utilizou a mesma proporção de 2:1, porém em um tempo de regeneração de 24 horas. Os resultados apresentados nas Figuras 51 e 52, para proporções estequiométricas de 1:1 e 1:2, com $24 \mathrm{~h}$ de regeneração, 
apresentaram comportamento semelhante aos experimentos apresentados nas Figuras 48 e 49, ou seja, para as estas proporções estequiométricas, nenhuma diferença significativa foi observada em razão de um maior tempo de regeneração.

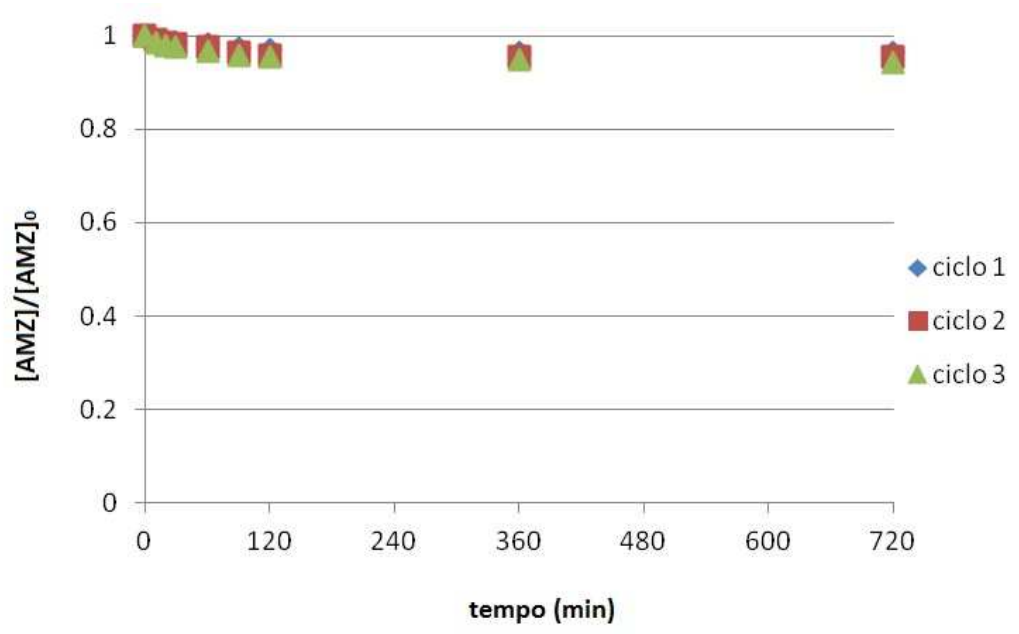

Figura 47 - Resultados dos ensaios de adsorção/regeneração. Regeneração do carvão ativado, por meio de processo oxidativo avançado com PMS, por 12 horas, na proporção molar oxidante/contaminante de 2:1 e pH próximo a 7.

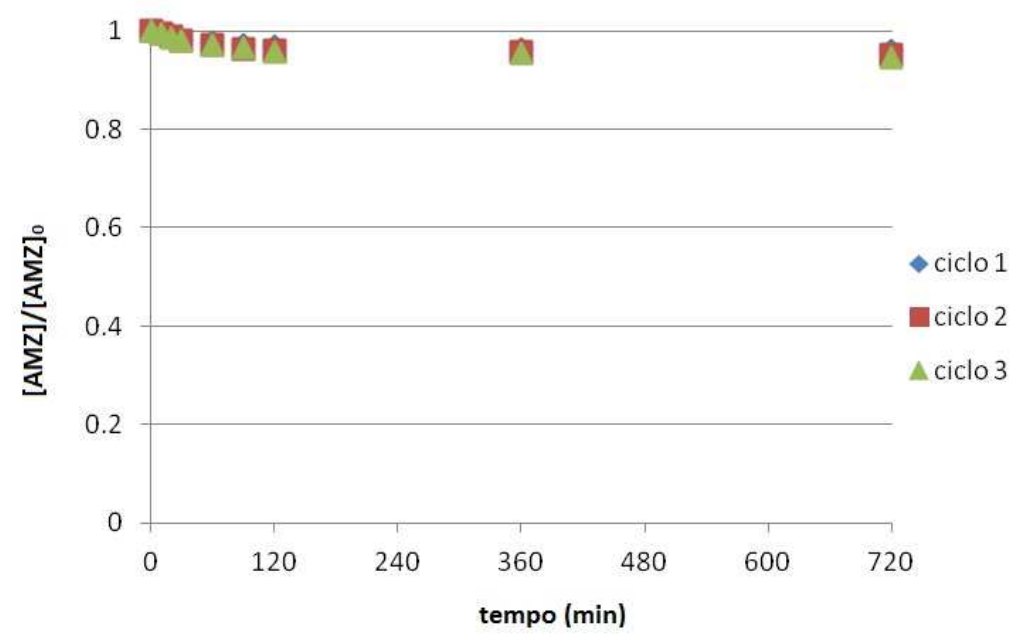

Figura 48 - Resultados dos ensaios de adsorção/regeneração. Regeneração do carvão ativado, por meio de processo oxidativo avançado com PMS, por 12 horas, na proporção molar oxidante/contaminante de 1:1 e pH próximo a 7. 


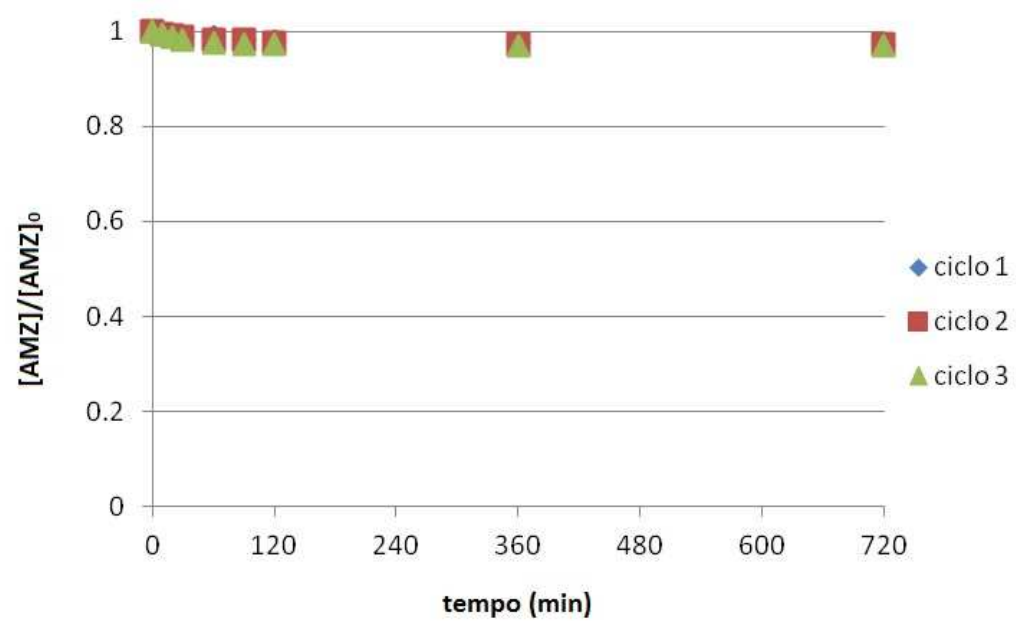

Figura 49 - Resultados dos ensaios de adsorção/regeneração. Regeneração do carvão ativado, por meio de processo oxidativo avançado com PMS, por 12 horas, na proporção molar oxidante/contaminante de 1:2 e pH próximo a 7.

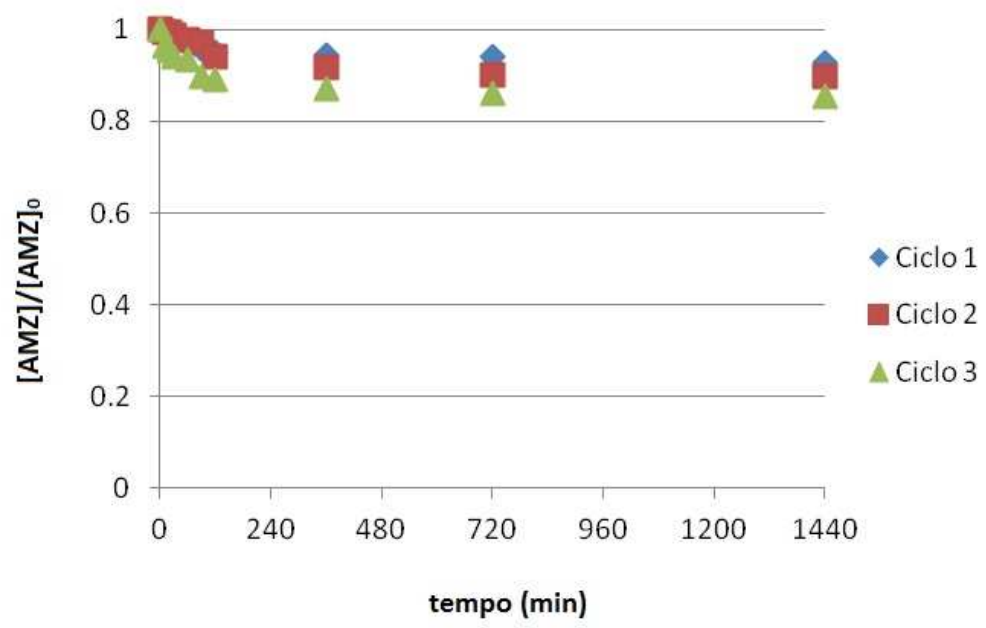

Figura 50 - Resultados dos ensaios de adsorção/regeneração. Regeneração do carvão ativado, por meio de processo oxidativo avançado com PMS, por 24 horas, na proporção molar oxidante/contaminante de 2:1 e pH próximo a 7. 


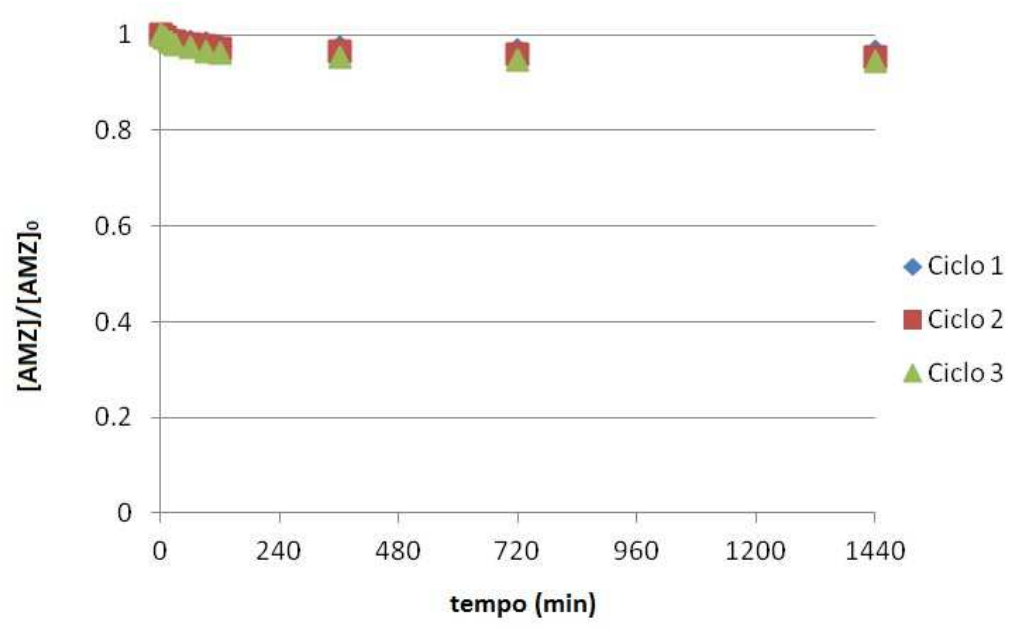

Figura 51 - Resultados dos ensaios de adsorção/regeneração. Regeneração do carvão ativado, por meio de processo oxidativo avançado com PMS, por 24 horas, na proporção molar oxidante/contaminante de 1:1 e pH próximo a 7.

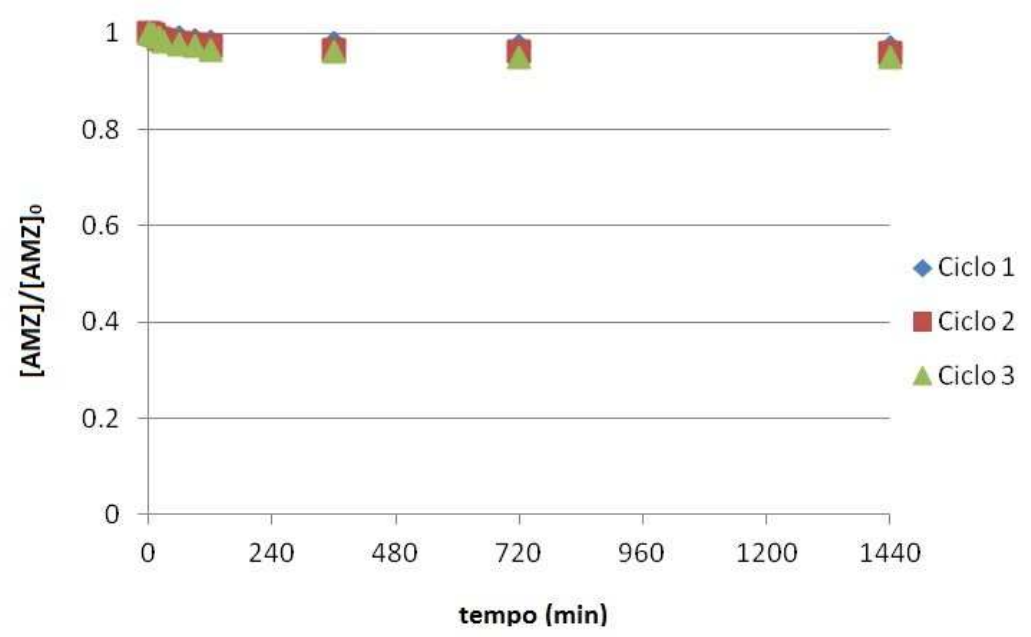

Figura 52 - Resultados dos ensaios de adsorção/regeneração. Regeneração do carvão ativado, por meio de processo oxidativo avançado com PMS, por 24 horas, na proporção molar oxidante/contaminante de 1:2 e pH próximo a 7.

A partir dos resultados apresentados, a regeneração usando PMS é aparentemente efetiva quando o carvão ativado ainda não se encontra completamente saturado, embora seja difícil caracterizá-la precisamente devido à pequena reprodutibilidade das curvas de adsorção obtidas no primeiro ciclo. Isso pode ser devido à própria amostra de carvão ativado ou às condições de agitação dos frascos nos experimentos. Com relação aos experimentos realizados com a condição de "saturação total", os resultados para a regeneração foram menos satisfatórios, ou seja, em geral não se observou melhora significativa na 
capacidade do carvão ativado adsorver o herbicida amicarbazona, quando comparados com os experimentos realizados quando a condição de saturação ainda não estava completamente estabelecida. Nestes, ao invés de diminuir o poder de adsorção, como seria o esperado, ele aumentou, sugerindo que o carvão apresentou sua capacidade de adsorção restituída. Por outro lado, no caso dos carvões contendo grande quantidade de amicarbazona previamente adsorvida, os resultados sugerem que apenas a combinação de tempos muito grandes de tratamento (superiores a 24 horas) e com altas concentrações de oxidante (PMS:AMZ=30:1) seriam necessários o que, porém, não parece adequado tendo em vista a operação em escala comercial. 


\section{CONCLUSÕES}

O presente trabalho mostra a viabilidade da regeneração de um carvão ativado comercial contaminado com amicarbazona (AMZ), por meio de Processos Oxidativos Avançados. O planejamento experimental Doehlert permitiu encontrar condições adequadas (massa de carvão e concentração de pesticida), para dar início aos experimentos.

A amicarbazona é um herbicida do grupo das triazolinonas, que apresenta estabilidade química em meio ácido e neutro e instabilidade química em meio fortemente alcalino $(\mathrm{pH}>9)$, com consequente hidrólise, por isso controlou-se o $\mathrm{pH}$ durante a realização dos experimentos.

$\mathrm{Na}$ primeira etapa de caracterização do carvão ativado, não foi possível verificar grandes diferenças em sua estrutura e origem com relação a outros carvões que pudessem explicar os diferentes comportamentos observados no processo de adsorção. Com a finalidade de tentar uniformizar os testes, realizouse a separação granulométrica do carvão, porém mesmo assim algumas diferenças foram observadas, o que pode ser devido aos poros internos do mesmo.

Com relação à regeneração o processo $\mathrm{H}_{2} \mathrm{O}_{2} / \mathrm{UV}$ se mostrou efetivo, já que se observou uma manutenção na capacidade de adsorção após a regeneração. Com relação ao peróximonossulfato de potássio, os únicos experimentos iniciais (sem saturação do carvão ativado) que não mostraram melhoria no desempenho durante o processo de oxidação foram os dois realizados com tempo de regeneração de 1 hora, independentemente da proporção estequiométrica utilizada, o que se mostra adequado, uma vez que o PMS é um oxidante solúvel e de fácil manuseio, o que facilita o processo de regeneração.

Em um segundo momento, repetiram-se os experimentos de regeneração por meio do processo oxidativo avançado PMS utilizando-se amostras de carvão ativado contendo amicarbazona previamente adsorvida. Os resultados sugeriram que não houve melhora significativa na capacidade de adsorção do carvão ativado após ciclos consecutivos de adsorção-regeneração, já que a pequena diferença observada nas concentrações residuais do herbicida pode estar 
associada ao erro experimental e analítico. Mesmo após a adição de um excesso de oxidante, não se observou diferença significativa quanto ao desempenho da adsorção.

Por fim, a partir dos resultados apresentados, a regeneração usando PMS é aparentemente efetiva quando o carvão ativado ainda não se encontra completamente saturado, embora seja difícil caracterizá-la precisamente devido à pequena reprodutibilidade das curvas de adsorção obtidas no primeiro ciclo. Observou-se, ainda, que o tempo de regeneração, aliado à proporção oxidante/contaminente mais alta, influenciou positivamente o desempenho do carvão ativado não saturado, ou seja, levou ao aumento de sua capacidade de adsorção da amicarbazona. 


\section{REFERÊNCIAS BIBLIOGRÁFICAS}

AHMEDNA, M.; MARSHALL, W. E.; RAO, R. M. Production of granular activated carbons from select agricultural by-products and evaluation of their physical, chemical and adsorption properties. Biosource Technology, v. 71, p. 113-123, 2000.

ALPHACARBO. Origens e Caracteristicas - Preservando a qualidade de vida com qualidade e respeito. Disponivel em: http://www.alphacarbo.com.br/origens.php. Acesso em: 17 de setembro de 2011.

ALMEIDA, E.; ASSALIN, M.R.; ROSA, M.A. Tratamento de efluentes industriais por procesos oxidativos na presença de ozônio, Química Nova, v.27, n.5, p.818824, 2004.

ALVAREZ, P.M.; BELTRAN, F.J.; MASA, F.J. POCOSTALES, J.P. A Comparison between catalytic ozonation and activated carbon adsorption/ozone-regeneration processes for wastewater treatment. Applied Catalysis B-Environmental, v. 92, p. $393-400,2009$.

AMAT A. M.; ARQUES, A.; LÓPEZ, F.; MIRANDA, M.A. Solar photo-catalysis to remove paper mill wastewater pollutants. Solar Energy, v.79, n.4, p. 393-401, 2005.

AMORIM, C.C.; LEÃO, M.M.D.; MOREIRA, R.F.P.M., Comparação entre diferentes processos oxidativos avançados para degradação de corante azo. Eng Sanit Ambient, v.1, n.4, p. 543-550, 2009.

ANIPSITAKIS, G.P. Cobalt/Peroxymonosulfate and Related Oxidizing reagents for Water treatmente. 2005. 219p., Tese (doutorado) - Department of Civil and Environmental Engineering, University of Cincinnati, Cincinnati, 2005.

ANISPITAKIS, G.P.; DIONYSIOU, D. D. Transition metal/UV-based advanced oxidation technologies for water decontamination. Applied Catalysis B: Environmental, v. 54, n. 3, p. 155-163, 2004.

ANTONIOU, M. G.; CRUZ, A. A.; DIONYSIOU, D. D. Degradation of microcystinLR using sulfate radicals generated through photolysis, thermolysis and e-transfer mechanisms. Applied Catalysis B: Environmental, v. 96, p. 290-298, 2010.

AREND, L. G.; RODRIGUEZ, A.L.; LOPEZ, D.A.R.; MAHLMAN, C.; OLIVEIRA, F.; NIEDERSBERG, C. Estudo da dissolução de plástico proveniente de resíduos sólidos urbano para obtenção de material adsorvente. In: 17ํㅜㅇ CBECIMat - Congresso Brasileiro de Engenharia de Materiais, p. 9208 - 9215, Foz do Iguaçu, 2006.

ASSUNÇÃO, R.S. Avaliação das emissões de compostos orgânicos voláteis (VOCs) em operações de carga e descarga de derivados líquidos de 
petróleo. 2003. 38 p. Monografia de conclusão de curso - Universidade Federal da Bahia, Departamento de hidráulica e saneamento, Salvador, 2003.

ATKINS, P.; JONES, L. Princípios de Química: questionando a vida moderna e o meio ambiente. Ed.: Bookman, Porto Alegre, 2001.

BACAOUI, A; YAACOUBI, A; DAHBI, A; BENNOUNA, C; LUU, R. P. T.; MALDONADO-HODAR, F. J.; RIVERA-UTRILLA, J.; MORENO-CASTILLA, C. Optimization of conditions for the preparation of activated carbons from olivewaste cakes. Carbon, v. 39, p. 425- 432, 2001.

BACHEGA, T. F.; PAVANI, M. CM.D; ALVES, P.L.C.A.; SAES, L.P.; BOSCHIERO, M. Lixiviação de sulfentrazone e amicarbazone em colunas de solo com adição de óleo mineral. Planta Daninha, v. 27, n. 2, p. 363-370, 2009.

BRUNAUER, S.; EMMETT, P.H.; TELLER, E. Adsorption os gases in multimolecular Layers. Disponível em: http://dns2.asia.edu.tw/ ysho/YSHOEnglish/1000\%20WC/PDF/J\%20Ame\%20Che\%20Soc60,\%20309.pdf. Acesso em: 02 de dezembro de 2012.

CALGON Carbon Corporation. Laboratory Evaluation of Granular Activated Carbon for Liquid Phase Applications, 2007. Disponível em: http://www.calgoncarbon.com/solutions/literature.html. Acesso em: 10 de dezembro de 2011.

CARVÃO Ativo. Universidade Federal de São João Del Rei, 2008. Disponivel em: http://www.ufsj.edu.br/dcnat/carvao_ativo.php. Acesso em: 14 de janeiro de 2012.

CENDOFANTI, A.C. Minimização de resíduos de um processo de carvão ativado e de goma resina. 2005. 109 p. Dissertação (Mestrado) - Universidade Federal do Paraná, Departamento de engenharia de recursos hídricos, Curitiba, 2005.

CLAUDINO, A. Preparação de carvão ativado a partir de turfa e sua utilização na remoção de poluentes. 2003. 93 p. Dissertação (Mestrado) - Universidade Federal de santa Catarina, Departamento de Engenharia Química, Florianópolis, 2003.

CORBI, J. J.; STRIXINO, S. T.; SANTOS, A.; GRANDE, M. Diagnóstico ambiental de metais e organoclorados em córregos adjacentes a áreas de cultivo de cana de-açúcar (Estado de São Paulo, Brasil). Química Nova, v. 29, n. 1, p. 61 - 65, 2006.

COSTA, L. L. F.; SANT'ANA, E. S.; SUCHARA, E. A.; BENATO, V. S.; CARASEK, E. Determinação de herbicidas usados no cultivo de arroz irrigado na região sul do Estado de Santa Catarina através da SPME-GC-ECD. Química Nova, v. 31, n.1, p. 79- 83, 2008. 
CRISTINO, W. Tratamento de efluentes têxtil contendo corante reativo violeta 5: comparação entre os processos oxidativos avançados irradiados e não irradiados. 2006. 136p., Dissertação (mestrado) - Engenharia de Processos Químicos, Escola de Engenharia Mauá do Centro Universitário do Instituo Mauá de Tecnologia, São Caetano do Sul, 2006.

DABEK, L.; SWIATKOWSKI, A. Nonconventional rpocesses for regeneration of spent activated carbons. Przemysl Chemiczny, v. 88, p. 650 - 655, 2009.

DABROWSKI, A.; PODKOSCIELNY, P.; HUBICKI, Z.; BARCZAK, M. Adsorpotion of phenolic compounds by activated carbon - A critical review. Chemosphere, $v$. 58, p. 1049-1070, 2005.

DAYAN, F.E.; TRINDADE, M.L.B.; VELINI, E.D. Amicarbazone, a New Photosystem II Inhibitor, Weed Science, v. 57, p. 579-583, 2009.

DE SÁ, I.C.G. Estudo fitoquímico de Rhabdodendron amazoniucum, Conchocarpus inopinatus e avaliação dos compostos isolados na inibição da fotossíntese. 111p. Dissertação (Mestrado) - Universidade Federal de São Carlos, Departamento de Química, São Carlos, 2010.

DOMINGUES, M.R.; BERNARDI, M.R.; ONO, E.Y.S.; ONO, M.A. Agrotóxicos: Risco à saúde do trabalhador rural. Semina: Ciências Biológicas e da Saúde, v.25, p.45-54, 2004.

DUBININ, M.M. Adsorption equations for active carbons with inhomogeneous microporous structures. Carbon, v. 17, p. 505-506, 1979.

EPA - United States Environmental Protection Agency. Pesticide Fact Sheet. Disponível em: http://www.epa.gov/opprd001/factsheets/amicarbazone.pdf. Acesso em: 25 de julho de 2011.

ESPLUGAS, S.; GIMÉNEZ, J.; CONTRERAS, S.; PASCUAL, E.; RODRIGUEZ, M. Comparison of different advanced oxidation processes for phenol degradation. Water research, v. 36, p. 1034-1042, 2002.

FERREIRA, L.O. Avaliação de diferentes adsorventes na recuperação de metanol utilizado em cromatografia líquida de alta eficiência (CLAE). 2006. 80p., Dissertação (Mestrado) - Uniersidade do estado do Rio de Janeiro, Instituto de Química, Rio de janeiro, 2006.

FILHO, J. S. B.; MARCELINO, M. P. A.; DUTRA, F. Efeito de diferentes metais de transição na decomposição de persulfato em Processos Oxidativos Avançados aplicados em solos. In: 30ª Reunião Anual da Sociedade Brasileira de Química, Águas de Lindóia, SP, 2007.

FOGLER, H.S. Elements of Chemical Reaction Engineering, ed. 3, Prentice - Hall PTR, 1998. 
FREIRE, R.S.; PELEGRINI, R.; KUBOTA, L. T.; DURÁN, N. Novas Tendências para o tratamento de resíduos industriais contendo espécies organocloradas. Química Nova, v. 23, n. 4, 2000, p. 504-511.

GOMIDE, R. Operações Unitárias, Edição do autor, São Paulo, 1980.

GRUPTA, V.K.; GRUPTA, B.; RASTOGI, A.; AGARWAL, S. Pesticides removal from waste water by activated carbon prepared from waste rubber tire. Water research, v. 45, p. $4047-4055,2011$.

HARRIOTT, P.; CHENG, A.T. Kinetics of Spent Activated Carbon Regeneration. AIChE Journal, v. 34, n. 10, p. 1656 - 1662, 1988.

HORNG, R.S.; TSENG, I.C., Regeneration of granular activated carbon saturated with acetone and isopropyl alcohol via a recirculation process under $\mathrm{H}_{2} \mathrm{O}_{2} / \mathrm{UV}$ oxidation. Journal of Hazardous Materials, v. 154, p. 366-372, 2008. .

HULING, S.G.; KO, S.; PARK, S.; KAN, E. Persulfate oxidation of MTBE - and chloroform-spent granular activated carbon. Journal of Hazardous Materials, v. 192, p. $1484-1490,2011$.

IBGE - Diretoria de Pesquisa, Coordenação de População e Indicadores Sociais, Pesquisa Nacional e Saneamente Básico. Tabela de resultados: Esgotamento Sanitário. Disponível em: http://www.ibge.gov.br/home/estatistica/populacao/condicaodevida/pnsb2008/tabe las_pdf/tab054.pdf. Acesso em: 02 de dezembro de 2012.

IGNATOWICZ, K. A mass transfer model for the adsorption of pesticide on coconut shell based activated carbon. International Journal of Heat and Mass Transfer, n. 54, p. 4931 - 4938, 2011.

INCE, N. H.; APIKYAN, I.G. Combination of activated carbón adsorption with lightenhanced chemical oxidation via hydrogen peroxide. Water Research, v. 34, n. 17, p. 4169-4176, 2000.

JUSOH, A.; HARTINI, W.J.H.; ALI, N. ENDUT.A. Study on the removal of perticide in agricultural run off by granular activated carbon. Bioresource Technology, $n$. 102, p. $5312-5318,2011$.

KANIA, N.; RIO, S.; MONFLIER, E.; PONCHEI, A. Cyclodextrins adsorbed onto activated carbons: Preparation, characterization, and effect on the dispersibility of the particles in water. Jounal of Colloid and Interface Science, v. 371, p. $89-100$, 2012.

KUNZ, A. Remediação de efluente têxtil: combinação entre processo químico (ozônio) e biológico. 1999. Tese (Doutorado) - Universidade estadual de Campinas, Instituto de Química, Campinas, 1999. 
LAINE, J.; CALAFAT, A.; LABADY M. Preparation and characterization of activated carbons from coconut shell impregnated with phosphoric acid. Carbon, v. 27, p. 191-195, 1989.

LIANG, C.; LIN, Y. T.; SHIH, W.H. Treatment of trichloroethylene by adsorption and persulfate oxidation in batch studies. Industrial \& Engineering Chemistry Research, v. 48, p. 8373-8380, 2009.

LITTRELL, K. C.; KHALILI, N. R.; CAMPBELL, M; SANDI, G; THIYAGARAJAN, P.. Microstructural analysis of activated carbons prepared from paper mill sludge by SANS and BET. Chemistry of materials, v. 14, p. 327-333, 2002.

MALATO, S.; BLANCO, J.; VIDAL,A.; RICHTER, C. Photocatalysis with solar energy at a pilot-plant scale: An overview. Applied Catalysis B: Environmenal, v. 37, p. 1-15, 2002.

MARTIN, R.J.; NG, W.J. The repeated exhaustion and chemical regeneration of activated carbon. Water Research, v.21, n.8, p. 961-965, 1987.

MEZZARI, I. A. Utilização de carvões adsorventes para o tratamento de efluentes contendo pesticidas. 2002. 117p. Dissertação (Mestrado) Universidade de Santa Catarina, Departamento de Engenharia Química, Florianópolis, 2002.

MINATO, M. Y. Estudo da eficiência da remoção do fenol de soluções quosas em cátodo de carvão ativado via elétron fenton. 2010. 98p. Dissertação (Mestrado) - Universidade Federal do Rio de Janeiro, Departamento de Engenharia Metalúrgica e de Materiais, Rio de Janeiro, 2010.

MORAES, S.G. Processo fotocatalítico combinado com processos biológicos no tratamento de efluentes têxteis. 1999. $160 \mathrm{p}$. Tese (Doutorado) Departamento de Química, UNICAMP, Campinas, 1999.

MORAIS, J.L. Estudo da potencialidade de processos oxidativos avançados, isolados e integrados com processos biológicos tradicionais, para tratamento de chorume de aterro sanitário. 2005. 229 p., Tese (Doutorado) Universidade Federal do Paraná, Instituto de Química, Curitiba, 2005.

MORENO, R.M.; JÚNIOR, E.C.A.; FRANCO, T.T. Predição da porosidade e capacidade de adsorção em carvões ativados utilizando iodo e azul de metileno. In: VI Congresso Brasileiro de Engenharia Química em Iniciação Científica, 2005, Campinas.

MORLAY, C.; QUIVET, E.; PILSHOFER, M.; FAURE, B.; JOLY, J.P. Adsorption of Imazamox herbicide onto Filtrasorb 400 activated carbon, Journal of Porous Materials, v. 19, p. $79-86,2012$. 
MOURAND, J.T.; CRITTENDEN, J.C.; HAND, D.W.; PERRAM, D.L.; NOTTHAKUN,S. Regeneration of Spent adsorbents using homogeneous advanced oxidation. Water environment Research, v. 67, p. 355-363, 1995.

MURANAKA, C. T. Combinação de adsorção por carvão ativado com Processo Oxidativo Avançado (POA) para tratamento de efluentes contendo fenol. 2010. 165p., Tese (Doutorado) - Escola Politécnica de São Paulo, Departamento de Engenharia Química, São Paulo, 2010.

Nogueira, R.F.P et al., Simple and fast spectrophotometric determination of $\mathrm{H}_{2} \mathrm{O}_{2}$ in photo-Fenton reactions using metavanadate. Talanta. 2005.

OPPENLÄNDER, T. Photochemical Purification of Water and Air: Advanced Oxidation Processes (AOPs): Principles, Reaction Mechanisms, Reactor Concepts, Weinhein: Wiley-VCH, 2003.

PAIVA, T. C. B. Caracterização e tratamento de efluente de branqueamento TCF de indústria de papel e celulose. 1999. Tese (Doutorado) - Universidade estadual de Campinas, Instituto de Química, Campinas, 1999.

PARRA, S. Coupling of photocatalytic and biological process as a contribuition to the detoxification of water: catalytic and technological aspects. 2001. 170 p. Tese (doutorado) - École Polytechnique Féderale De Lausanne, Département de Génie Rural, Lusanne, 2001.

PASTOR-VILLEGAS, J; GOMEZ-SERRANO, V; DURAN-VALLE, C. J.; HIGESROLANDO, F. J. Chemical study of extracted rockrose and of chars and activated carbons prepared at different temperatures. Journal of analytical and applied pyrolysis, v. 50, p. 1-16, 1999.

PAWLOWSKY, U.; PATZA, M.G.; RODA, L.A.; GABARDO, M.T. Tratabilidade de efluentes de produção de pesticidas. In: Anais do 190 Congresso Brasileiro de Engenharia Sanitária e Ambiental, Foz do Iguaçu. 1997.

PÉREZ-FLORINDO, A., et al., CO2 - Carbon gasification catalyzed by alkaline earths: comparative study of the metal-carbon interaction and of the specificactivity, Carbon, v. 31, p.493-500, 1993.

PHILBROOK, B. D.; KREMER, M.; MUELLER, K. H.; DEEGE, R. BAY MKH 3586 - a new herbicide for broad spectrum weed control in corn (maize) and sugar cane. Brighton Conference - Weeds, v. 1, p. 29-34, 1999.

PIVELI, R.P.; KATO, M.T. Qualidade das águas e poluição: aspectos físicoquímicos. 285p., São Paulo, Ed. ABES, 2006.

PORTAL São Francisco. Distribuição da água. Disponível em: http://www.portalsaofrancisco.com.br/alfa/meio-ambiente-agua/distribuicao-daagua.php). Acesso em: 15 de abril de 2011. 
PRADHAN, B.K.; SANDLE, N.K. Effect of different oxidizing agent treatments on the surface properties of activated carbons. Carbon. v. 37, p. 1323-1332, 1999.

RAMOS, P.H.; GUERREIRO, M.C.; RESENDE, E.C. GONÇALVES, M. Produção e caracterização de carvão ativado produzido a partir do defeito preto, verde, ardido (PVA) do café. Química Nova, v. 35, n. 5, p. 1139- 1143, 2009.

ROCHA, W.D. Carvão ativado a partir de resíduos agrícolas e suas aplicações na adsorção de íons metálicos. 2006. 126 p., Dissertação (Mestrado) - Universidade Federal de Ouro Preto, Departamento de Engenharia Mineral da Escola de Minas, Ouro Preto, 2006.

RUTHVEN, D.M. Principles of Adsorption and adsorption Processes, John Wiley \& Sons, New York, 1984.

SALMAN, J.M.;NJOKU, V.O.; HAMMED, B.H. Adsorption of pesticides from aqueous solution onto banana stalk activated carbon. Chemical Engineering Journal, v. 174, p. $41-48,2011$.

SANTIAGO, B.H.S.; FRANCA, G.H.C.; FERNANDES, R.; SELVAM, P.V.P. Estudo da viabilidade tecno-economica preliminar para produção de carvão ativado no Brasil a partir dos resíduos do coco: estudo comparativo de cenários de produção. Revista Analytica, n. 17, 2005.

SARRIA, V.; DERONT, M.; PERINGER,P.; PULGARIN C. Degradation of a biorecalcitrant dye precursor present in industrial wastewaters by a new integrated iron (III) photoassisted-biological treatment. Apple Catalysis B, v. 40, n. 3, p. 231246, 2003.

SCHNEIDER, E.L. Adsorção de compostos fenólicos sobre carvão ativado. 2008. 93p., Dissertação (Mestrado) - Universidade estadual do oeste do Paraná, Departamento de Engenharia Química, Toledo, 2008.

SHEINTUCH, M. ; MEYTAL, Y. Compaison of catalytic processes with other regeneration methods of activated carbon. Catalysis Today, v. 53, p.13-80, 1999.

SHEMER, H.; SHARPLESS, C. M.; ELOVITZ, M. S.; LINDEN, K. G. Relative rate constants of contaminant candidate list pesticides with hydroxyl radicals. Environ. Sci.Technol., v. 40, n. 14, p. 4460 - 4466, 2006.

SNOEYINK, V. L.; WEBER, W. J. The surface chemistry of active carbon; a discussion of structure and surface functional groups. Environ. Sci. Technol., v. 1, n.3, p. 228-34, 1967.

SOUZA, B.M. Avaliação de processos oxidativos avançados acoplados com carvão ativado granulado com biofilme para reuso de efluentes de refinaria de petróleo. 2010. 179 p., Dissertação (Mestrado) - Universidade Federal do Rio de Janeiro, Departamento de Engenharia Química, Rio de Janeiro, 2010. 
SOUZA, J.R.; PERECIN, D.; AZANIA, C.A.M.; SCHIAVETTO, A.R.; PIZZO, I.V.; CANDIDO, L.S. Tolerância de cultivares de cana-de-açúcar a herbicidas aplicados em pós-emergência. Bragantia, Campinas, v. 68, n. 04, p. 941-951, 2009.

TAGLIAFERRO, G. V.; PEREIRA, P. H. F.; RODRIGUES, L. A.; DA ILVA, M. L. C. Adsorção de chumbo, cádmio e prata em óxido de nióbio (V) hidratado preparado pelo método da precipitação em solução homogênea. Química Nova, v. 34, n. 1, p. 101- 105, 2011.

TEIXEIRA, W.; TOLEDO, M. C. M. de; FAIRCHILD, T. R.; TAIOLI, F. Decifrando a Terra. São Paulo, Ed. Oficina de Textos, 2008.

TOMAZ, P. A Economia de Água para Empresas e Residências - Um Estudo Atualizado sobre o Uso Racional da Água. Navegar Editora, São Paulo, 2001.

TRATAMENTO de efluentes e destinação dos resíduos de ensaios por líquidos penetrantes. In: $6^{\text {a }}$ Conferência sobre tecnologia de equipamentos, Salvador, 2002, autor desconhecido. Disponível em: < http://www.aaende.org.ar/sitio/biblioteca/material/PDF/COTE166.PDF>. Acesso em: 13 de agosto de 2010.

ZHANG, Z.P.; TAY, J.H.; SHOW, K.Y.; YAN, R.; LIANG, D.T.; LEE, D.J.; JIANG, W.J. Biohydrogen production in a granular activated carbon anaerobic fluidized bed reactor. International Journal of Hydrogen Energy, v. 32, p. $185-191$, 2007. 